Philippus Wester

Arabinda Mishra

Aditi Mukherji

Arun Bhakta Shrestha

Editors

The Hindu Kush

Himalaya

Assessment

Mountains, Climate Change,

Sustainability and People

ICIMOD HIMAP

Springer Open 
The Hindu Kush Himalaya Assessment 
Philippus Wester • Arabinda Mishra Aditi Mukherji - Arun Bhakta Shrestha Editors

\section{The Hindu Kush Himalaya Assessment}

Mountains, Climate Change, Sustainability and People

ICIMOD 
Editors

Philippus Wester

International Centre for Integrated Mountain

Development (ICIMOD)

Kathmandu, Nepal

Arabinda Mishra

International Centre for Integrated Mountain

Development (ICIMOD)

Kathmandu, Nepal
Aditi Mukherji

International Centre for Integrated Mountain

Development (ICIMOD)

Kathmandu, Nepal

Arun Bhakta Shrestha

International Centre for Integrated Mountain

Development (ICIMOD)

Kathmandu, Nepal
ISBN 978-3-319-92287-4 (hardcover)

ISBN 978-3-319-95051-8 (softcover 2019)

https://doi.org/10.1007/978-3-319-92288-1
ISBN 978-3-319-92288-1 (eBook)

Published for the Hindu Kush Himalayan Monitoring and Assessment Programme (HIMAP)

Library of Congress Control Number: 2018954855

(C) ICIMOD, The Editor(s) (if applicable) and The Author(s) 2019, First softcover printing 2019. This book is an open access publication.

Open Access This book is licensed under the terms of the Creative Commons Attribution 4.0 International License (http://creativecommons.org/licenses/by/4.0/), which permits use, sharing, adaptation, distribution and reproduction in any medium or format, as long as you give appropriate credit to the original author(s) and the source, provide a link to the Creative Commons licence and indicate if changes were made.

The images or other third party material in this book are included in the book's Creative Commons licence, unless indicated otherwise in a credit line to the material. If material is not included in the book's Creative Commons licence and your intended use is not permitted by statutory regulation or exceeds the permitted use, you will need to obtain permission directly from the copyright holder.

The use of general descriptive names, registered names, trademarks, service marks, etc. in this publication does not imply, even in the absence of a specific statement, that such names are exempt from the relevant protective laws and regulations and therefore free for general use.

The publisher, the authors, and the editors are safe to assume that the advice and information in this book are believed to be true and accurate at the date of publication. Neither the publisher nor the authors or the editors give a warranty, express or implied, with respect to the material contained herein or for any errors or omissions that may have been made. The publisher remains neutral with regard to jurisdictional claims in published maps and institutional affiliations.

Photo credit: Cover photo by Santosh Raj Pathak

This Springer imprint is published by the registered company Springer Nature Switzerland AG

The registered company address is: Gewerbestrasse 11, 6330 Cham, Switzerland 


\title{
Status and Change of the Cryosphere in the Extended Hindu Kush Himalaya Region
}

\author{
Coordinating Lead Authors \\ Tobias Bolch, Institut für Geographie, University of Zurich, Zurich, Switzerland, \\ e-mail: tobias.bolch@geo.uzh.ch \\ Joseph M. Shea, International Centre for Integrated Mountain Development, Kathmandu, Nepal, Geography \\ Program, University of Northern British Columbia, Prince George, Canada, and Centre for Hydrology, \\ University of Saskatchewan, Saskatoon, Canada, e-mail: joseph.shea@unbc.ca (corresponding author) \\ Shiyin Liu, Institute of International Rivers and Eco-security, Yunnan University, Kunming, China, \\ e-mail: shiyin.liu@ynu.edu.cn
}

\section{Lead Authors}

Farooq M. Azam, Indian Institute of Technology, Indore, India, National Institute of Hydrology, Roorkee, India, e-mail: farooqaman@yahoo.co.in

Yang Gao, Chinese Academy of Sciences, Beijing, China, e-mail: Yanggao@itpcas.ac.cn Stephan Gruber, Geography and Environmental Studies, Carleton University, Ottawa, Canada, e-mail: stephan.gruber@carleton.ca

Walter W. Immerzeel, International Centre for Integrated Mountain Development, Kathmandu, Nepal, Department of Physical Geography, Utrecht University, Utrecht, the Netherlands, e-mail: w.w.immerzeel@uu.nl

Anil Kulkarni, Divecha Center for Climate Change, Centre for Atmospheric \& Oceanic Sciences, Indian Institute of Science, Bangalore, India, e-mail: anilkul54@gmail.com

Huilin Li, Northwest Institute of Eco-Environment and Resources, Chinese Academy of Sciences, China, e-mail: lihuilin@lzb.ac.cn

Adnan A. Tahir, Department of Environmental Sciences, COMSATS University Islamabad (CUI)-Abbottabad Campus, Abbottabad, Pakistan, e-mail: uaf_adnan@hotmail.fr

Guoqing Zhang, Institute of Tibetan Plateau Research, Chinese Academy of Sciences, Beijing, China, e-mail: guoqing.zhang@itpcas.ac.cn

Yinsheng Zhang, Institute of Tibetan Plateau Research, Chinese Academy of Sciences, Beijing, China, e-mail: yszhang@itpcas.ac.cn

\section{Contributing Authors}

Argha Bannerjee, Indian Institute of Science Education Research, Pune, India, e-mail: argha@iiserpune.ac.in Etienne Berthier, CNRS, LEGOS, University of Toulouse, e-mail: etienne.berthier@legos.obs-mip.fr Fanny Brun, CNRS, LEGOS, University of Toulouse, Universite Grenoble Alpes, Grenoble, France, e-mail: fanny.brun@univ-grenoble-alpes.fr

Andreas Kääb, Department of Geosciences, Oslo University, Oslo, Norway, e-mail: andreas.kaab@geo.uio.no Phillip Kraaijenbrink, Department of Physical Geography, Utrecht University, Utrecht, the Netherlands, e-mail: P.D.A.Kraaijenbrink@uu.nl

Geir Moholdt, Norwegian Polar Institute, Tromsø, Norway, e-mail: geir.moholdt@npolar.no

Lindsey Nicholson, Department of Atmospheric and Cryospheric Sciences, Universität Innsbruck, Innsbruck, Austria, e-mail: lindsey.nicholson@uibk.ac.at

Nicholas Pepin, Department of Geography, University of Portsmouth, UK, e-mail: nicholas.pepin@port.ac.uk Adina Racoviteanu, Department of Geography and Earth Sciences, Aberystwyth University, Aberystwyth, UK, e-mail: racovite@gmail.com

\section{Electronic supplementary material}

The online version of this chapter (https://doi.org/10.1007/978-3-31992288-1_7) contains supplementary material, which is available to authorized users. 


\section{Review Editor}

Koji Fujita, Graduate School of Environmental Studies, Nagoya University, Nagoya, Japan, e-mail: cozy@nagoya-u.jp

\section{Corresponding Author}

Joseph M. Shea, International Centre for Integrated Mountain Development, Kathmandu, Nepal, Geography Program, University of Northern British Columbia, Prince George, Canada, and Centre for Hydrology,

University of Saskatchewan, Saskatoon, Canada, e-mail: joseph.shea@unbc.ca

\section{Contents}

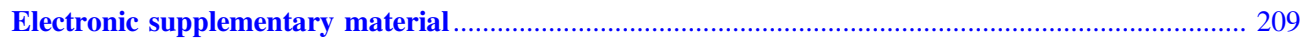

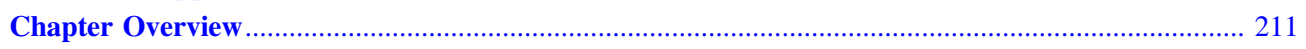

7.1 Situating the Cryosphere in the Hindu Kush Himalaya

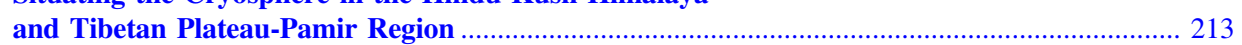

7.1.1 Defining the Extended HKH Region from a Cryosphere Perspective........................................ 213

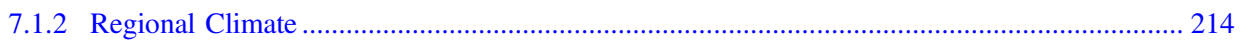

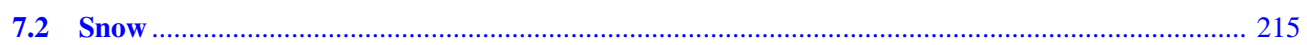

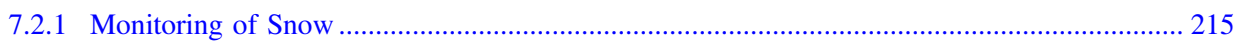

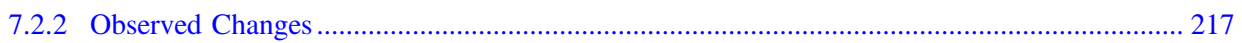

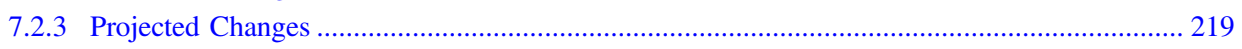

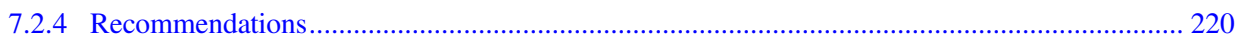

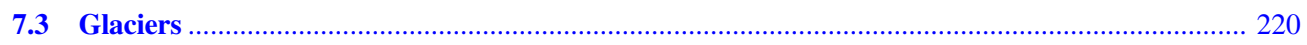

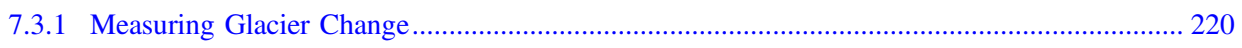

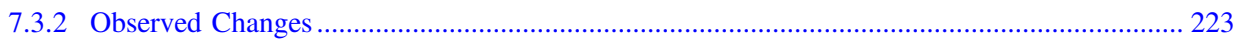

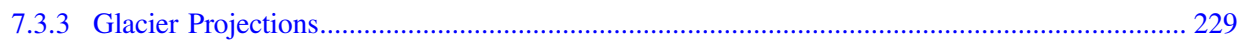

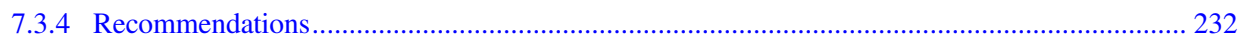

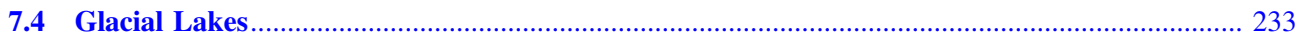

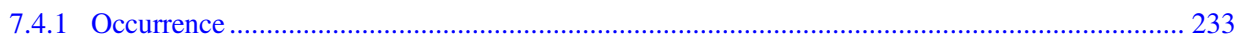

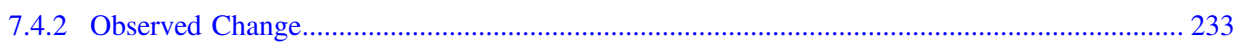

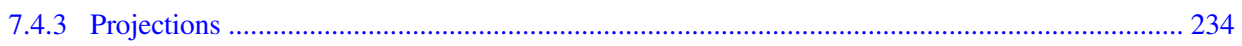

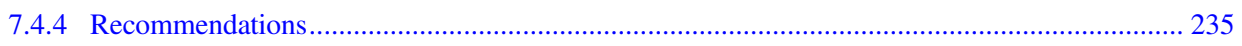

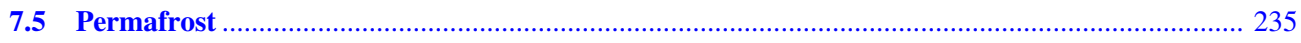

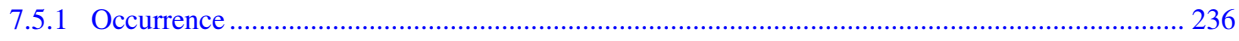

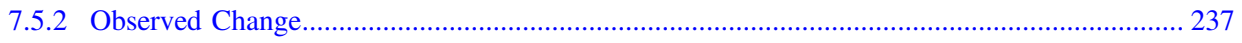

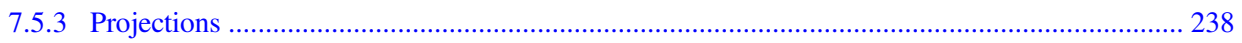

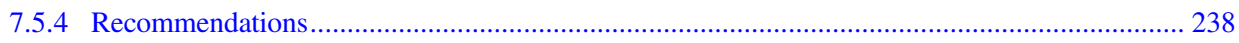

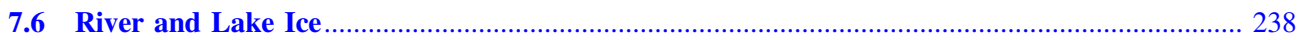

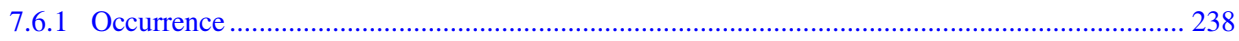

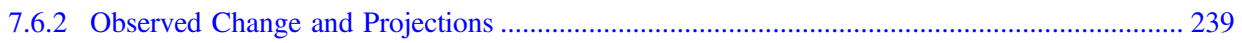

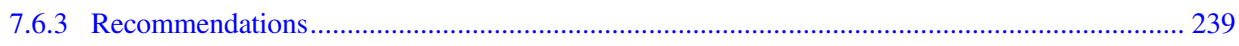

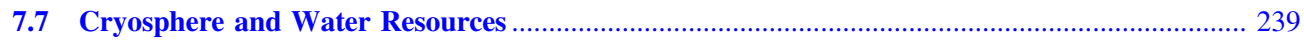

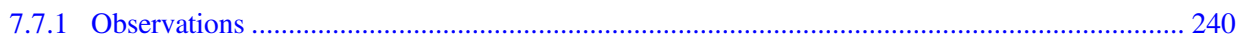

7.7.2 Projections of Cryospheric and Hydrological Change ........................................................ 241

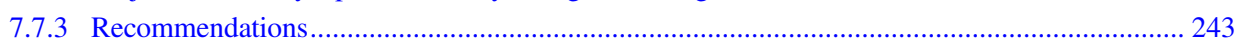

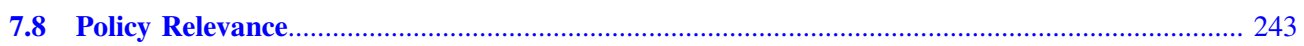

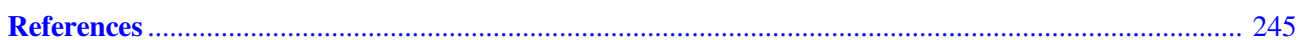




\section{Chapter Overview}

\section{Key Findings}

1. The cryosphere-snow, ice, and permafrost-is an important part of the water supply in the extended Hindu Kush Himalaya region. Observed and projected changes in the cryosphere will affect the timing and magnitude of streamflows across the region, with proportionally greater impacts upstream. Cryospheric change will have modest impacts on total annual streamflows in large river systems but will strongly affect the timing and seasonal distribution of runoff, which is relevant for both ecology and economy. As snow and ice melt provide a reliable source of meltwater during warmer months, the cryosphere helps to buffer against changes in streamflows due to climate change and monsoon variability.

2. There is high confidence that snow-covered areas and snow volumes will decrease in most regions over the coming decades in response to increased temperatures, and that snowline elevations will rise. The greatest changes in snow accumulations will be observed in regions with higher mean annual temperatures. Projected changes in snow volumes and snowline elevations $(+400$ to $+900 \mathrm{~m})$ will affect seasonal water storage and mountain streamflows.

3. Glaciers have thinned, retreated, and lost mass since the 1970s, except for parts of the Karakoram, eastern Pamir, and western Kunlun. Trends of increased mass loss are projected to continue in most regions, with possibly large consequences for the timing and magnitude of glacier melt runoff and glacier lake expansion. Glacier volumes are projected to decline by up to $90 \%$ through the 21 st century in response to decreased snowfall, increased snowline elevations, and longer melt seasons. Lower emission pathways should, however, reduce the total volume loss.

4. There is high confidence that permafrost will continue to thaw and the active layer (seasonally thawed upper soil layer) thickness will increase. Projected permafrost degradation will destabilize some high mountain slopes and peaks, cause local changes in hydrology, and threaten transportation infrastructure.

\section{Policy Messages}

1. To reduce and slow cryospheric change, international agreements must mitigate climate change through emission reductions. Lower emission pathways will reduce overall cryospheric change and reduce secondary impacts on water resources from mountain headwaters.

2. To better monitor and model cryospheric change and to assess spatial patterns and trends, researchers urgently need expanded observation networks and data-sharing agreements across the extended HKH region. This should include in situ and detailed remote sensing observations on selected glaciers, rapid access to high-resolution satellite imagery, improved and expanded snow depth and snow water equivalent measurements, and ground temperatures and active layer thickness measurements in different regions, aspects and elevations.

3. Improved understanding of cryospheric change and its drivers will help reduce the risk of high-mountain hazards. Glacier lake outburst floods (GLOFs), mass movements (rockfalls, avalanches, debris flows), and glacier collapses present significant risks to mountain residents. This risk can be minimized with improved observations and models of cryospheric processes.

The cryosphere is defined by the presence of frozen water in its many forms: glaciers, ice caps, ice sheets, snow, permafrost, and river and lake ice. In the extended Hindu Kush Himalaya (HKH) region, which includes the Pamirs, Tien Shan, and Tibetan Plateau ranges, the cryosphere is a key freshwater resource, playing a vital and significant role in local and regional hydrology and ecology. Industry, agriculture, and hydroelectric power generation rely on timely and sufficient delivery of water in major river systems; changes in the cryospheric system may also pose challenges for disaster risk reduction in the extended HKH region.

Surveying the status and trends of the extended $\mathrm{HKH}$ cryosphere requires a detailed and comprehensive analysis of all its parts. The response of these components to climate change varies in both space and time. Recent glacier mass and area changes exhibit important regional variations, and the response times of snow cover and permafrost to climate change are vastly different. This chapter summarizes the 
current status of cryospheric components in the extended HKH, examines patterns and impacts of change, and synthesizes cryospheric change projections in response to representative concentration pathway (RCP) scenarios. We further identify significant knowledge gaps and consider the policy relevance of cryospheric research.

Snow is an important seasonal water storage component in the extended HKH and, in many areas, a critical source of streamflow for irrigation (Chap. 8). Yet snowfall totals at high elevations are poorly known. Long-term measurements of snow water equivalent (SWE) and solid precipitation are needed to test gridded data sets (i.e., regionalized precipitation data based on physical modelling and/or interpolation based on existing in situ measurements) or remote sensing-derived precipitation data sets. As snow cover in the extended $\mathrm{HKH}$ is highly variable and satellite-derived records are short, observed trends in snow cover are generally weak and inconsistent between studies and regions. Future projections point towards reduced snow cover and lower basin-wide SWE, although regional differences exist due to synoptic setting.

Glacier meltwater provides a regular and reliable source of streamflow in glacierized river basins. Such predictability is especially vital in the post-monsoon season and for regions with lower summer precipitation. According to a compilation of glacier mass and area change studies, glaciers in most regions are shrinking and losing mass. However, glaciers in the eastern Pamir, Karakoram, and western Kunlun Shan have lost less mass than others, and since at least 2000 have had balanced mass budgets or even slight mass gains.

Projections of glacier change are consistent across studies: glacier mass loss will accelerate through the 21 st century, and higher-emission scenarios will result in even greater mass loss. The rise of regional equilibrium line altitudes (ELAs) will eventually result in the complete disappearance of debris-free lower elevation glaciers, and will increase volume losses from glaciers with high-elevation accumulation areas.

Glacial lakes occur frequently in the extended HKH, and numerous new lakes will form in response to cryospheric change. Since the 1990s, glacial lakes show a clear increase both in number and in area. Both the largest total glacial lake area and the greatest absolute glacial lake growth rate appear in the eastern and central Himalaya. Several glacial lakes in the extended $\mathrm{HKH}$ are potentially hazardous - and as glaciers continue to retreat, the risk of dangerous glacial lake outburst floods (GLOFs) may increase further. More assessments, projections, and impact studies are needed to clarify GLOF risks across the extended HKH.
Permafrost exists beneath large parts of the extended HKH -yet its occurrence and importance is not widely known in the region. As permafrost cannot easily be seen, it is easy to ignore. Yet permafrost can shape many climate impacts on cold regions. Although detailed data are scarce, existing measurement sites indicate permafrost warming, with an increase in the depth of the active layer. Thawing permafrost can reduce ground stability and cause a range of problems, from undermining engineered structures, to increased occurrence of rockfalls, and increased outburst potential of glacier lakes. In addition, thawing permafrost affects the hydrological cycle: water stored in ground ice may be released or near-surface soil water availability may decline as the active layer thickens.

Continued neglect of permafrost in large parts of the extended HKH could limit future capacity for adaptation and risk reduction programmes, as relevant environmental trends will be misjudged or missed completely. Progress will depend on learning more about the physical characteristics of permafrost in the extended HKH and about its causal links with human activity. Furthermore, observation networks are required for developing and testing simulation tools specific to extended HKH conditions.

Information about lake and river ice has been identified as a suitable proxy for mean air temperatures and their variability. However, very few studies address changes in lake ice coverage, freeze dates, and break-up dates. In situ observations are almost non-existent. Remote sensing-based studies show ice coverage declining in larger lakes since 1980, but no clear trend emerges for the period 2000-12. While no future projections exist, it is likely that with a continuous increase in air temperature, ice coverage will decrease further.

Hydrological trends related to cryospheric change are difficult to identify for three reasons: confounding influences on discharge, scarcity of long-term data sets, and high interannual variability in discharge that masks any temporal trends. Nevertheless, large volumes of snow and ice in the extended $\mathrm{HKH}$ are important regional water supplies-more so as one looks further upstream. An increase in air temperature will reduce snowpack accumulations and result in earlier and lower snowmelt runoff volumes. Medium- and long-term changes in glaciers and permafrost will reduce summer melt contributions.

Our synthesis of the scientific literature on cryospheric change in the extended HKH suggests that more resources are needed for cryospheric change impact studies-both regional-and sector-specific. High-level international agreements should promote systematic data collection, data sharing, training of local and regional scientists and technicians, and the development of cryosphere-related hazard 
warning systems. Above all, stronger global commitments are needed to reduce greenhouse gas emissions, as all projections indicate that lower emission futures result in reduced cryospheric change.

Reliable, freely available, and continuous in situ measurements of glaciers, snowpacks, permafrost, meteorology, and hydrology are lacking within the extended HKH. In addition, we identify the following critical research gaps for which urgent action is needed:

1. Better SWE observations and estimates are needed for high mountain areas; long-term snow course monitoring sites and strategies should be developed.

2. Glacier volume change estimates prior to 2000 are currently unavailable for several regions - a gap that researchers can now fill, however, using declassified satellite imagery.

3. We lack detailed studies of high-elevation snow accumulation and snowmelt processes and scenarios concerning future snowpack properties.

4. Well-documented, reliable, and long-term hydrological observations are needed across different climate zones and elevations to assess uncertainty and variability in discharge observations, and to improve and develop models of hydrological change

5. Although many studies quantify glacier area and volume change, few try to diagnose the reasons for these changes. Better models of future glacier change will require a closer focus on regional glacier sensitivity and the causes of regional glacier change.

\section{Cryosphere and the Sustainable Development}

Goals With its fundamental role in regulating the supply of water in the extended $\mathrm{HKH}$, the cryosphere is important to achieving several Sustainable Development Goals (SDGs). These include the following:

1. SDG 6-Ensure availability and sustainable management of water and sanitation for all. Snow and ice melt contributions to streamflow vary across the extended $\mathrm{HKH}$, and they are more important upstream than downstream. Yet they provide a reliable water source, and they can buffer against years or months of drought or low precipitation.

2. SDG 7-Ensure access to affordable, reliable, sustainable, and modern energy for all. The cryosphere contributes to hydroelectric power generation. Snow and ice are short- and medium-term water reservoirs; their depletion may constrain hydroelectric power generation during low-flow seasons and affect long-term energy production.

3. SDG 13-Take urgent action to combat climate change and its impacts. The future of the cryosphere depends in part on international agreements to mitigate climate change through emission reductions. Such reductions will ultimately reduce the total impact of climate change on the extended HKH cryosphere.

\subsection{Situating the Cryosphere in the Hindu Kush Himalaya and Tibetan Plateau-Pamir Region}

The Hindu Kush-Himalaya and Tibetan Plateau-Pamir includes the world's highest mountains and probably the greatest range of climatic conditions that can be observed over a distance of a few hundred kilometres anywhere on the planet. Influenced by both the summer monsoon and westerly low pressure systems, the occurrence of snow, ice, and permafrost is governed by the mountain topography and how it interacts with prevailing atmospheric circulation patterns. This section outlines the regional definitions used to examine cryospheric change and provides a short introduction to the climatic characteristics of the region. For detailed information regarding the climate, we refer to Chap. 3 on climate change.

\subsubsection{Defining the Extended HKH Region from a Cryosphere Perspective}

This assessment investigates the high mountain regions of the Hindu Kush, Karakoram, Himalaya, and Tibetan Plateau. The whole of the Pamir is also included in the assessment since parts of the Pamir are frequently included in studies addressing the Tibetan Plateau, and the remaining parts provide important additional information to understand the variability of the cryospheric changes. For simplicity, we refer to the entire region as the extended HKH region, and define it in this chapter to include the Hindu KushKarakoram-Himalaya-Tibetan Plateau-Pamir mountains.

To provide a suitable regional overview and highlight regional variations in cryospheric trends, we divide the extended HKH into 22 subregions (Fig. 7.1). The divisions were based on existing regional delineations (Gurung 1999; Shi et al. 2008; Shroder 2011) updated according to the topographical and climatological characteristics (e.g., 


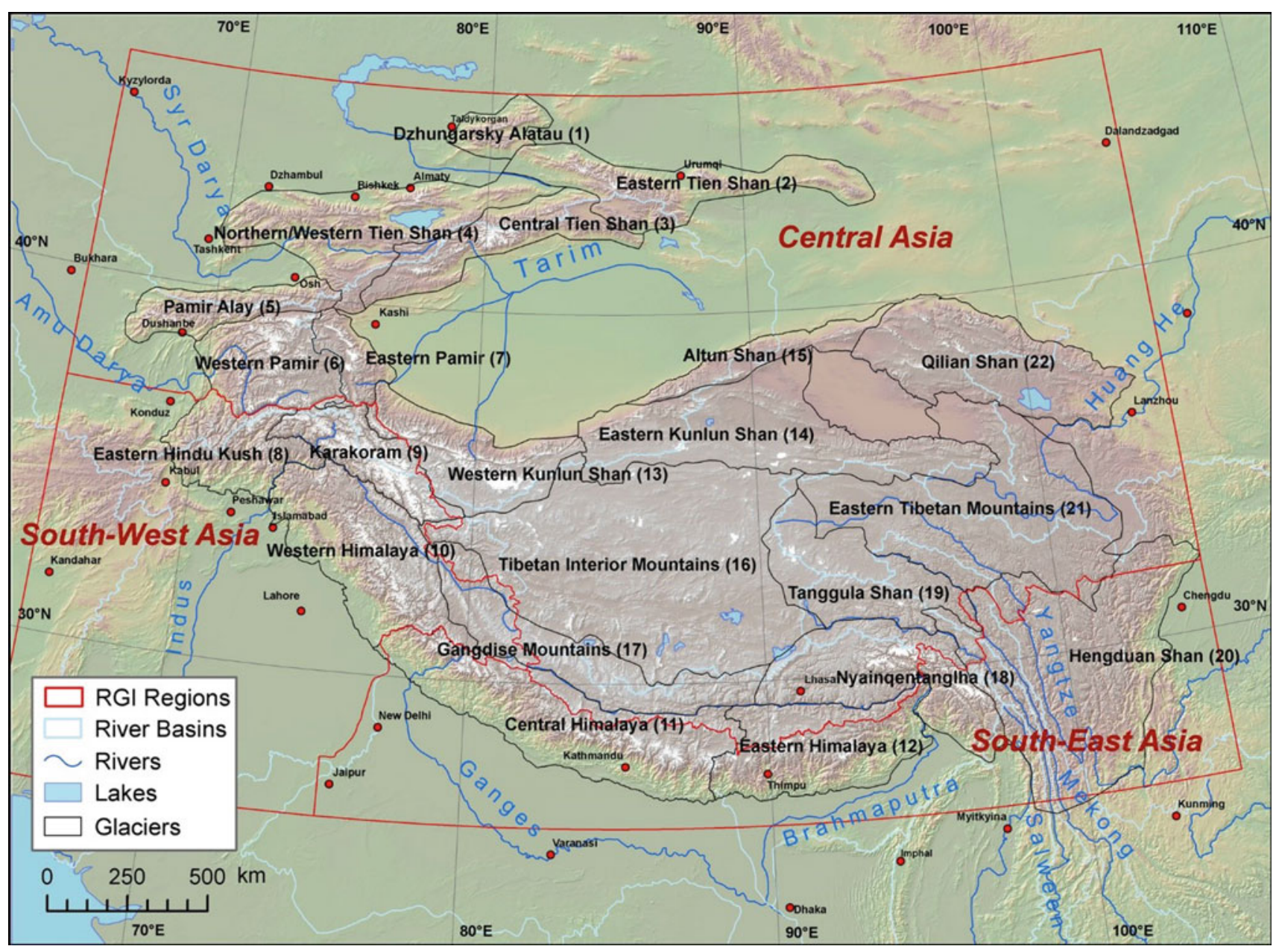

Fig. 7.1 High mountains of Asia showing the extended HKH subregions (06-22) used in this assessment (black), the Randolph Glacier Inventory (RGI) regions (red), and major rivers (blue)

Maussion et al. 2014) of the different mountain ranges. Regional glacier modelling studies typically use the larger region definitions given by the Randolph Glacier Inventory (RGI; Pfeffer et al. 2014), and these are also used here (Fig. 7.1).

\subsubsection{Regional Climate}

The extended HKH is characterized by extreme topographic and climatic heterogeneity. Interactions between atmospheric circulation and the world's tallest mountains produce strong horizontal and vertical gradients in both temperature and precipitation. In general, the climate is influenced by the East Asian and Indian monsoon systems, which deliver the bulk of precipitation in the central and eastern Himalayas between June and September (Bookhagen and Burbank 2006), with annual precipitation totals of up to 3,000 $\mathrm{mm}$ (Maussion et al. 2014; Bookhagen and Burbank 2010). In the western part of the region, westerly disturbances in winter account for high snowfall ratios (over 80\%) in annual precipitation rates of 1,000-2,000 mm (Barlow et al. 2005; Bookhagen and Burbank 2010; Hewitt 2011; Maussion et al. 2014), but winters in the monsoon-dominated central and eastern areas are dry (Shrestha et al. 2000). As a result of the topography, mean annual temperatures can vary up to $40{ }^{\circ} \mathrm{C}$ over distances of a few hundred kilometres, and strong gradients of precipitation exist across the mountain ranges (Shrestha et al. 2012).

While precipitation typically increases with elevation due to orographic forcing (Barry 1992), the extreme elevations and heterogeneity encountered in the extended HKH results in vertical precipitation gradients that vary both in space (Andermann et al. 2011) and time (Collier and Immerzeel 2015). In monsoon-dominated regions, the greatest precipitation rates are typically observed at elevations around 3,000 masl (Putkonen 2004; Bookhagen and Burbank 2006; Shrestha et al. 2012). However, in the Upper Indus basin, both observations and inverse glacier mass balance modelling suggest that precipitation above 5,000 masl can be five-to-ten times greater than that received in the valleys 
below (Hewitt et al. 1988; Winiger et al. 2005; Hewitt 2005; Duan et al. 2015b; Immerzeel et al. 2015). As the dynamics and mechanisms of precipitation delivery (orographic versus synoptic versus convective) vary throughout the region, vertical precipitation gradients cannot be generalized spatially or even seasonally. The spatial variability in climatic regimes could account for the spatial heterogeneity of glacier response (Sakai et al. 2015; Sakai and Fujita 2017). However, knowledge of precipitation gradients through remote sensing and/or ground-based measurements is critical for evaluating basin-wide snow water equivalences.

Trends in temperature and precipitation vary spatially across the extended HKH region (Malik et al. 2016) and are examined in detail in Chap. 3. Climatic change will likely be amplified by elevation-dependent warming (see Box 7.1), placing additional pressures on the extended $\mathrm{HKH}$ cryosphere.

\subsection{Snow}

Snow is a critical component of the extended HKH cryosphere. Northern hemisphere snow cover plays an important role in global hydrology and surface energy balance (Groisman et al. 1994), and regulates the global climate (Frei et al. 2012). Snow is also a critical short-term water storage mechanism (Zhang et al. 2012), with a potentially high sensitivity to future climate change (Barnett et al. 2005; Immerzeel et al. 2009). People in the river basins of the extended HKH region rely to a varying degree on snowmelt for drinking water, irrigation, and hydropower generation (Bookhagen and Burbank 2010; A. Lutz et al. 2014), while snow cover on the Tibetan Plateau has a profound influence on atmospheric circulation and the Asian monsoon ( $\mathrm{Wu}$ and Zhang 1998; Bansod et al. 2003; Qian et al. 2011). Changes in seasonal snow cover will directly impact the availability and seasonal distribution of fresh water in mountain river basins (Beniston 2003; Mukhopadhyay and Khan 2015) and will also affect permafrost via alterations in the thermal coupling between atmosphere and subsurface. This section explores how snow is measured, and summarizes the observed and projected changes in snow cover in the extended $\mathrm{HKH}$ region.

\subsubsection{Monitoring of Snow}

Snow is quantified through in situ measurements of snow depth, snow water equivalent (SWE), or as a precipitation volume. Annual snow accumulation rates can be estimated from glacier mass balance records (Sect. 7.3) and firn or ice cores. Remotely-sensed snow measurements include snow-covered area (SCA), snow-covered fraction (SCF), and derived quantities such as snow cover duration (SCD). Snowline elevations are also sensitive indicators of climate change, and are highly correlated with glacier equilibrium line altitudes (ELAs) and mass balance. Unfortunately, the lack of in situ observations represents a serious limitation to snow-related studies in the extended HKH (Rohrer et al. 2013; Salzmann et al. 2014).

\subsubsection{Field Measurement}

Field measurements are challenging to maintain in high mountain areas due to poor accessibility and challenging weather conditions (e.g., Germann et al. 2006; Palazzi et al. 2013; Shea et al. 2015a). There are a number of specific problems in measuring snowfall in the extended HKH. First, solid precipitation is difficult to measure in windy environments, and gauge undercatch can be a significant problem (Førland et al. 1996), but instruments that continually monitor SWE (e.g., snow pillows) directly are rare in the region (Hasson et al. 2014) and are also susceptible to errors. Second, most weather stations in the extended HKH lie below 5,000 masl (Shrestha et al. 1999; Fowler and Archer 2006; Ma et al. 2008) and are thus not representative of glacier accumulation areas or the elevation of maximum snow accumulation (Harper and Humphrey 2003; Immerzeel et al. 2015). Finally, available in situ data is usually fragmented and held by different stakeholders in the regional countries and not easily accessible (Dahri et al. 2016).

Point glacier mass balance measurements may be used to assess seasonal snow accumulations at high elevation locations, though this is complicated by wind erosion/drift, sublimation, and access difficulties. Ice cores and shallow firn cores provide an important method for evaluating past snow accumulation rates and can provide century-scale series of climatic data at high elevations where observations are sparse or non-existent (Kaspari et al. 2008; Duan et al. 2015a). However, possible locations for ice cores are limited, and the data are subject to the same complications as point mass balance measurements. Climate reconstructions have been made from ice cores taken from the Everest region (Kaspari et al. 2008), the Pamir (Aizen et al. 2009), and in several locations on the Tibetan Plateau (Thompson et al. 2000; Aizen et al. 2006).

\subsubsection{Remote Sensing Measurement}

Remote sensing offers one of the most promising sources of information on snow in the extended HKH, due to the large spatial extent of the region and the inaccessible terrain (Immerzeel et al. 2009). Optical remote sensing techniques have been used previously in the region to measure snow-covered area or fraction, snow cover duration, and albedo (Hall et al. 2006; Pu and Xu 2009; Frei et al. 2012; Brun et al. 2015). Active microwave sensors can provide 


\section{Box 7.1 Accelerated warming at high elevations}

Arctic amplification, whereby enhanced warming over time $(d T / d t)$ is evident at high latitudes (Serreze and Barry 2011; Hinzman et al. 2005), is well accepted amongst the scientific community. There is also strong theoretical reasoning indicating that this enhancement should apply at high elevations (Mountain Research Initiative EDW Working Group 2015). Elevation dependent warming (EDW) is encouraged by many physical mechanisms (Fig. 7.2). Changes in surface characteristics caused by snow/ice melt and treeline-migration will tend to decrease surface albedo and enhance $d T / d t$ in a particular elevation band as the snowline/treeline moves upslope (Fig. 7.2a). A warmer atmosphere can hold more moisture, which will encourage increased latent heat release, especially at high elevations (Fig. 7.2b). A moistening of the atmosphere will also increase downwelling of longwave radiation since water vapour is a greenhouse gas, but the effects of a given moistening will be increased at high elevations, which are currently very dry (Fig. 7.2c). Blackbody longwave radiation emissions are proportional to the fourth power of temperature;
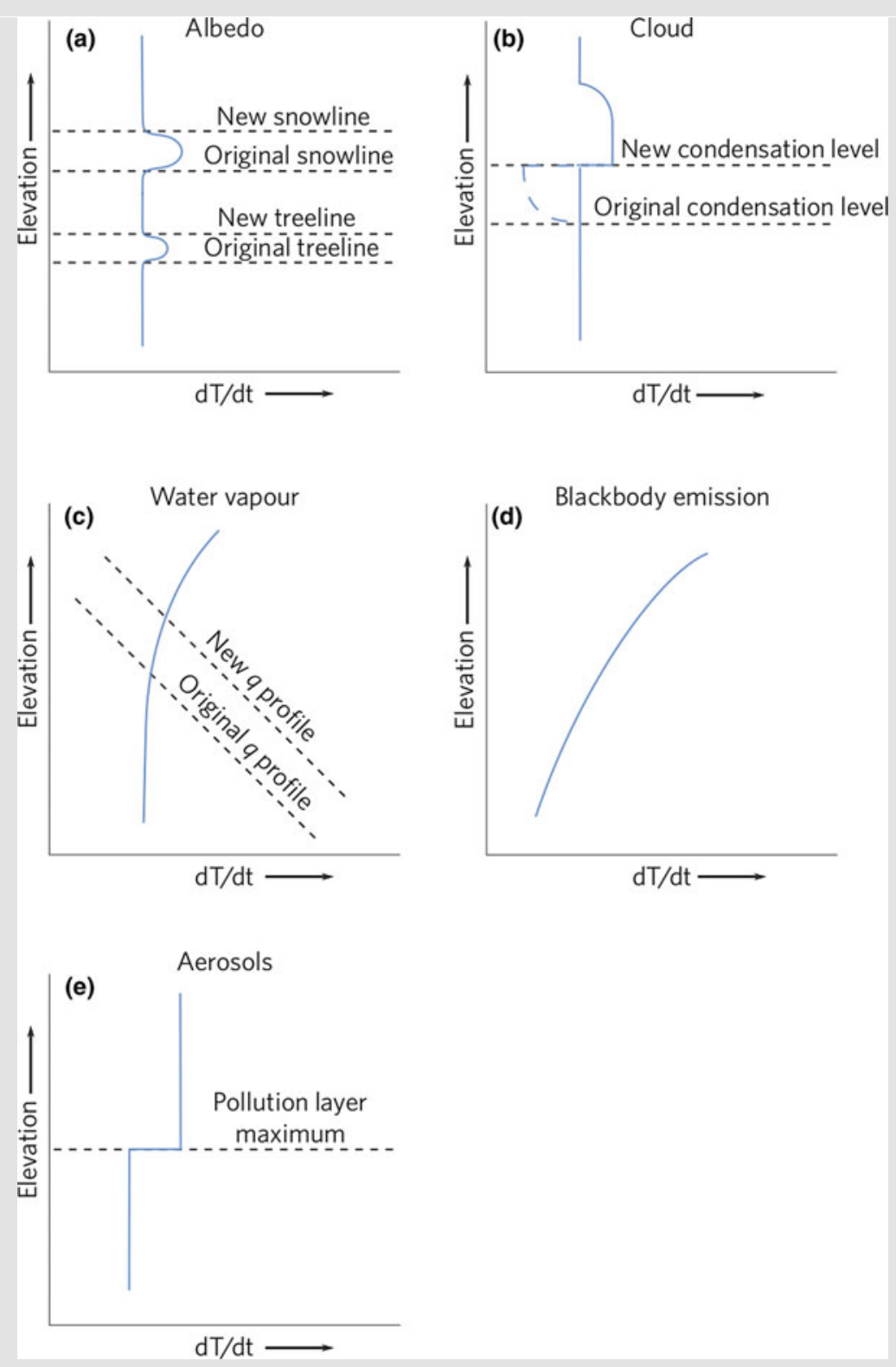

Fig. 7.2 Schematic diagrams of five mechanisms of elevation dependent warming. dT/dt is the change in temperature over time (adapted from Mountain Research Initiative EDW Working Group 2015) 
near-surface air temperature sensitivities will therefore be greater at the lower temperatures common in both high latitudes and high mountains (Fig. 7.2d). Finally, aerosols, in particular black carbon and dust, cause both global dimming at lower elevations (meaning less effect in high mountains) and, when deposited on snow and ice, encourage more rapid melt of glaciers (Fig. 7.2e). Combined, these five factors result in amplified warming observed in high-mountain environments in comparison to their adjacent lowlands.

Unfortunately, observational evidence of EDW is limited, primarily because of a lack of high elevation data. Surface stations are biased towards low elevations, satellites measure local surface temperature (which shows extreme local variability), and models, although very powerful tools, are usually not of high enough resolution to capture the complexities of high elevation terrain. Thus, it is possible that future climate changes in mountain regions are currently underestimated.

information about snow characteristics (Koskinen et al. 1997; Foster et al. 2011), snowmelt onset, and snow accumulation (Tedesco and Miller 2007).

Snowline elevations in the extended HKH have been monitored with a combination of optical imagery and digital elevation models (Thakuri et al. 2014; Wu et al. 2014; Kronenberg et al. 2016; Spiess et al. 2016). For temperate glaciers, snowline elevations at the end of the melt season are directly related to glacier mass balance (Dumont et al. 2012) and water resources (Winiger et al. 2005). But snowline elevations vary spatially and temporally, and are prone to rapid fluctuations in response to individual storm events.

From a water resources standpoint, distributed measurements of SWE are of primary importance as SWE relates directly to the water available for melt and streamflow. Passive microwave (PM) remote sensing, despite being subject to considerable uncertainties (Chang et al. 1987; König et al. 2001; Qin et al. 2006; Frei et al. 2012; Tiwari et al. 2016), offers a potentially useful tool to measure SWE (Smith and Bookhagen 2016). The typical resolution of PM sensors (e.g., Special Sensor Microwave/Imager, or SSM/I) is large (8$60 \mathrm{~km}$ ), but it has been used to monitor snowmelt onset in the western Pamirs (Vuyovich and Jacobs 2011).

Spaceborne radar has been used to measure precipitation rates and totals across the extended HKH (Anders et al. 2006; Bhatt and Nakamura 2006; Bookhagen and Burbank 2006; Yin et al. 2008). These studies indicate that the spatial pattern and magnitude of annual precipitation are consistent from year to year. Unfortunately, snowfall is not well captured by the Tropical Rainfall Measurement Mission (TRMM) platform, and only limited information can be obtained from satellites about high-elevation snowfall rates and accumulated SWE (Anders et al. 2006).

\subsubsection{Regional Differences in Snow Cover}

Snow cover varies considerably both spatially and temporally over the extended $\mathrm{HKH}$, but no study has systematically evaluated snow cover metrics (SCA, SCF, SCD) for the entire region. The average snow-covered area of the extended $\mathrm{HKH}$ ranges between 10 and $18 \%$, with mean maximum and mean minimum values of $21-42 \%$ in winter and $2-4 \%$ in summer (Immerzeel et al. 2009; Gurung et al. 2011). About $59 \%$ of the Tibetan Plateau is snow-covered in the winter, with the southeastern portion having the deepest and most persistent snow (Qin et al. 2006; Li et al. 2009). However, snow cover on the Tibetan Plateau is often shallow and patchy, and of short duration (Robinson and Dewey 1990; Qin et al. 2006).

Westerly-affected regions such as the Karakoram and Pamir have extensive winter snow cover (Xiao et al. 2007; $\mathrm{Pu}$ and $\mathrm{Xu}$ 2009; Zhou et al. 2013; Shen et al. 2015; Tahir et al. 2016), while snow cover in monsoon-dominated areas is limited to high elevations (Immerzeel et al. 2009; Dahri et al. 2011; Savoskul and Smakhtin 2013; Hasson et al. 2014; Singh et al. 2014). The snow-covered area in the upper Indus Basin (UIB) varies between 4 and 57\%, with the maximum occurring in spring; westerly-affected catchments within the UIB have a higher mean annual snow-covered area, at $51 \%$, than monsoon-dominated catchments, at $20 \%$ (Hasson et al. 2014). The UIB is generally more snow-covered than the entire extended HKH (Immerzeel et al. 2009), with an average annual snow-covered area value of $\sim 34 \%$ ( $12 \%$ in summer and $\sim 57 \%$ in spring). The snow-covered area in three entire large river basins (Indus, Ganges, and Brahmaputra) ranges from 85\% during snow accumulation periods to approximately $10 \%$ during ablation periods (Singh et al. 2014; Tahir et al. 2016).

\subsubsection{Observed Changes}

Information extracted from ice cores on the Tibetan Plateau shows decreased snow accumulation rates since the 1960s at many high-elevation sites (Thompson et al. 2000; Hou et al. 2002; Kehrwald et al. 2008; Kang et al. 2015; An et al. 2016). Coarse-resolution SSM-I products also show 


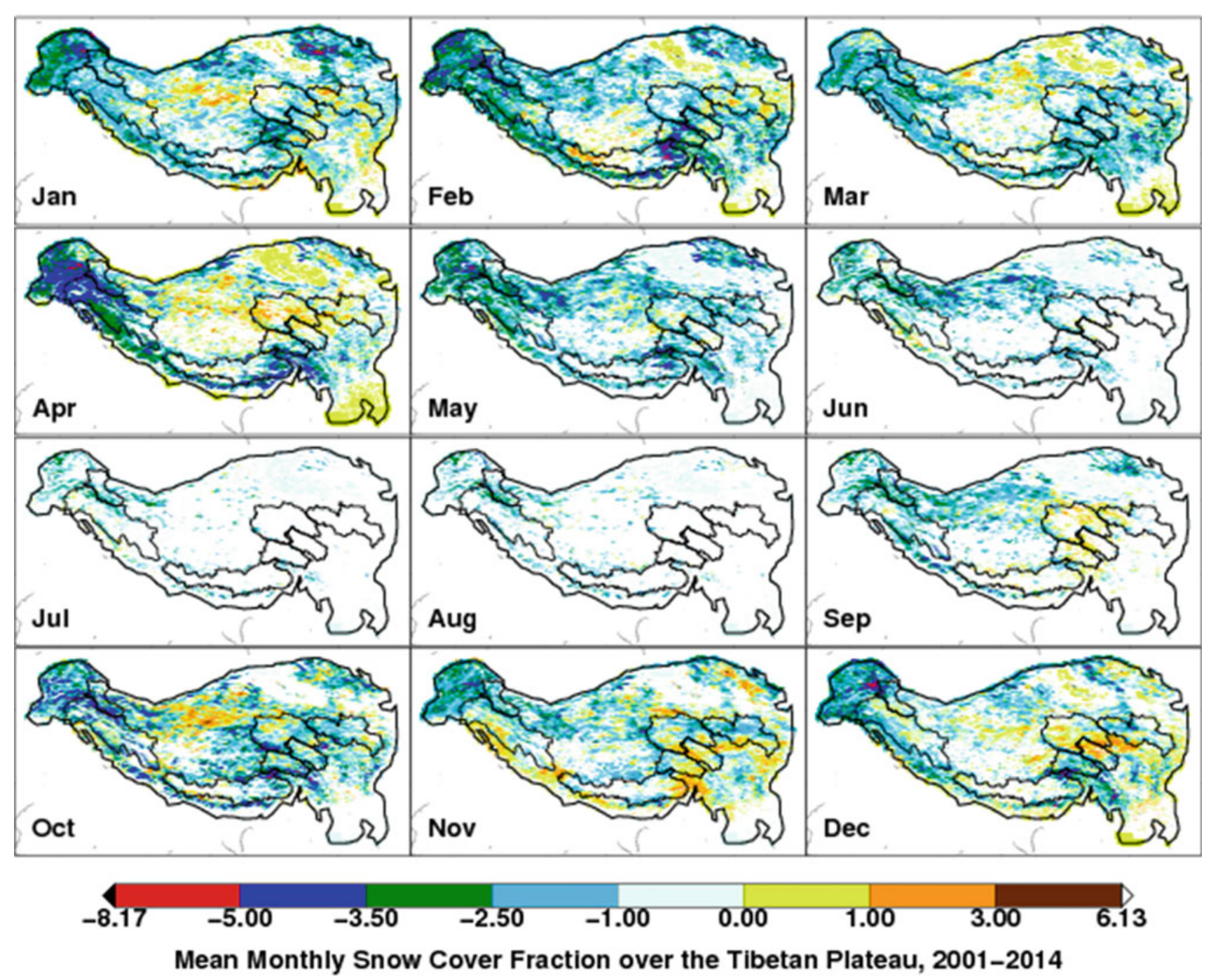

Fig. 7.3 Snow cover fraction trends (\%/yr) over the extended HKH from 2000 to 2014 (Source Li et al. 2017)

decreases in snow cover duration between 1966 and 2001 at all elevations across the extended HKH (Rikiishi and Nakasato 2006). Increases in winter SCA/SCF fraction have been observed in westerly-dominated basins since 2000 by most of the studies, and are either decreasing or stable elsewhere (Immerzeel et al. 2009; Hasson et al. 2014; Wang et al. 2015c; Tahir et al. 2016; Fig. 7.3). However, a recent study found a slightly decreasing trend of winter snow cover in the west based on similar data but a slightly longer period (2000-2014) (Li et al. 2017). This indicates the need for further investigations to resolve discrepancies.

\subsubsection{Hindu Kush-Himalaya-Karakoram}

The reported changes in snowline elevation, snow cover, and snow accumulation rates in the extended HKH are inconsistent. High interannual variability in snow cover and relatively short ( $<15$ years) datasets also prevent trend detection.
Annual snow-covered area trends over the entire extended HKH since 2000 are negative, but not significant (Gurung et al. 2011); slight increases (but still insignificant) have been observed in autumn in the central and eastern Himalayas, and in spring and summer in the western Himalayas (Gurung et al. 2011; Maskey et al. 2011; Wang et al. 2013a). At the river basin scale, snow-covered area increased in the Indus basin, but decreased in the Ganges and Brahmaputra basins between 2000 and 2011 (Singh et al. 2014). Late winter and spring snow cover, in particular, has decreased in the UIB since 2000 (Immerzeel et al. 2009; Mukhopadhyay 2012; Li et al. 2017).

End-of-summer snowline elevations in Himachal Pradesh rose by approximately $400 \mathrm{~m}$ between 1980 and 2007, a rate of $14.8 \mathrm{~m} / \mathrm{yr}$ (Pandey et al. 2013), while end-of-summer snowline elevations in the UIB lowered by $20 \mathrm{~m} / \mathrm{yr}$ between 2000 and 2011 (Hasson et al. 2014). 
Increased snow accumulation has been reported in the eastern extended HKH (Zhou et al. 2007), but this contrasts with results derived from ice cores from the Everest region which showed decreased snow accumulation totals since the 1970s (Kaspari et al. 2008). Modelled snowfall in the extended HKH region has decreased since 1861 (Kapnick et al. 2014). Glacier albedo, which depends on pollution (see Box 7.2), snow cover, and snowline elevation, has decreased at multiple sites in the extended HKH since 2000 (Ming et al. 2012; Brun et al. 2015; Xu et al. 2016). A positive trend in albedo was noted at Chhota Shigri Glacier (see Sect. 7.3), however, MODIS observations of albedo should be interpreted with caution.

\section{Box 7.2 Black carbon, dust, aerosols}

The Hindu Kush-Himalaya lies downwind of large sources of pollution produced by electricity generation, biomass burning, and brick factories. Short-lived climate pollutants (SLCPs) such as black carbon, dust, and other aerosols, affect snow and ice melt rates through direct and indirect effects. Direct effects include the darkening of the surface due to deposition, which will increase melt rates on snow in particular. However, black carbon and dust in the atmosphere also lead to local warming of the air mass. The net effect of SLCPs may be up to an order of magnitude greater than that observed from $\mathrm{CO}_{2}$ alone (Ramanathan and Carmichael 2008; Jacobi et al. 2015). SLCPs can lead to earlier melt onset, advanced snowline retreat, and an increase in annual glacier melt, but these impacts depend on the timing of deposition and local meteorology (Ménégoz et al. 2014). Knowledge of the temporal and spatial distribution of SLCPs, and in particular their distribution with elevation, will lead to improved estimates of their impact on snow and ice melt. Chapter 10 (Air Pollution) provides detailed information on air pollution sources and impacts.

\subsubsection{Pamir}

Snowmelt is of particular importance to river basins in central Asia (Aizen et al. 1995). Though records of snow cover are short, significant decreasing trends have been observed in snow cover duration in the Amu Darya basin (Zhou et al. 2013). Variations in snow cover duration can be caused by either earlier melt onset dates or delayed snow cover onset (Dietz et al. 2013). A decrease in maximum snow depth and snow cover duration has accompanied a general warming trend in the Muztag Ata region (Unger-Shayesteh et al. 2013). Confirmation of reduced snow accumulation in eastern Pamir since the 1970s was obtained from ice core measurements (Duan et al. 2015a).

\subsubsection{Tibetan Plateau}

Recent decreases in average annual and winter snow-covered fraction and snow depth have been observed on the Tibetan Plateau (Ma 2008; Wang et al. 2013b, 2015a; $\mathrm{Xu}$ et al. 2016; Fig. 7.3). As TP snow cover is generally thin and patchy (Qin et al. 2006), it is assumed to be highly sensitive to climate change (Pu et al. 2007; Li et al. 2008; Kang et al. 2010). Longer snow records based on station data suggest that snow cover increased between the $1950 \mathrm{~s}$ and late $1990 \mathrm{~s}$, with increased inter-annual variability since the mid-1980s (Qin et al. 2006), and it has been speculated that this may be due to changes in atmospheric water vapour content. Analyses of station data from 1951 to 2004 indicate that snow cover at the margins of the Tibetan Plateau is more sensitive to climate change than in the interior (Ma et al. 2010). Increases in both temperature and precipitation have resulted in an elevation-dependent snow cover response in eastern Tibet, with decreased snow cover duration at lower elevations and increased snow cover duration at higher elevations (Gao et al. 2012; Wang et al. 2015a).

\subsubsection{Projected Changes}

There are relatively few projections of future snowpack behaviour in the extended HKH. At the basin scale, high emission climate scenarios (RCP8.5) from the most recent Coupled Model Intercomparison Project (CMIP5) show snowfall reductions of $30-50 \%$ in the Indus Basin, $50-60 \%$ in the Ganges basin, and 50-70\% in the Brahmaputra Basin by 2071-2100 (Viste et al. 2015). A 50\% reduction in average basin SWE has also been projected for the Upper Indus by the 2050s (Bocchiola et al. 2011) under a 'business-as-usual' emission scenario (SRES A2). Snow depth reductions of 25$50 \%$ and $17-39 \%$ have also been projected for the Himalayas and Hindu Kush-Karakoram, respectively (Terzago et al. 2014), though an earlier modelling study of the Spiti River showed only a $1-7 \%$ decrease in SWE in response to a $+2{ }^{\circ} \mathrm{C}$ temperature increase (Singh and Kumar 1997). Projected decreases in end of winter SWE (Diffenbaugh et al. 2013) across the Himalaya may not be relevant to local hydrology, particularly in monsoon-dominated regions, since winter snow only comprises a small fraction of all snow here.

By 2100, snowline elevations are projected to rise between 400 and $900 \mathrm{~m}$ ( 4.4 to $10.0 \mathrm{~m} / \mathrm{yr})$ in the Indus, Ganges, and Brahmaputra basins under RCP8.5 emission scenarios (Viste et al. 2015). Coarse resolution general circulation models (GCMs) project a similar rate of rise in the freezing line altitude (zero degree isotherm) for the region (Ghatak et al. 2014). Chevallier et al. (2014) project a 
snowline rise of $4-7 \mathrm{~m} / \mathrm{yr}$ for the Pamir region. We note that these values are higher than the average $150 \mathrm{~m}$ increase in snowline that corresponds to a $1{ }^{\circ} \mathrm{C}$ increase in temperature in mountain regions (Beniston 2003).

In western China, snowfall totals may increase until mid-century (Li et al. 2008), while decreases are expected in eastern China and Inner Mongolia. Future decreases in snow cover and depth on the Qinghai-Tibetan Plateau (QTP) are dependent on emissions scenarios, with accelerated snow losses under high-emissions scenarios (Wei and Dong 2015).

\subsubsection{Recommendations}

Differences in reported snow cover trends may be due to differences in data sets, methodologies, areas covered, and time periods. Future snow cover research should aim for systematic basin-scale studies and consistent methodologies. Remote sensing missions and products developed for sustained monitoring are critical to reduce the uncertainties associated with the present lack of coherence in observing systems.

Our review identifies a number of key areas that have not been addressed in the published literature with respect to snow. These include:

- More robust estimates of regional snowline elevation change based on time-series of optical satellite imagery (as opposed to end-of-season snapshots, which are not suitable for monsoon climates)

- Regional studies of the rain-snow limit: how does it vary spatially and temporally? What are the implications of a temperature increase on solid/liquid precipitation volumes?

- Detailed studies of pollution transport and the impacts of regional pollution on the surface energy balance of high-elevation snowpacks (Box 7.2) are required to examine the cascading effects on snow hydrology and glacier mass balance.

- Attribution of snow cover extent and duration changes to meteorological conditions should be considered. What drives the spatial variability in snowpack changes?

- Improvement in the resolution and frequency of microwave SWE monitoring from satellites

\subsection{Glaciers}

Glaciers are important indicators of climate change (IPCC 2013). Glacier meltwater contributes to the discharge of major Asian rivers (Immerzeel et al. 2010) and feeds endorheic lakes on the Tibetan Plateau (Zhang et al. 2013). The importance of the glacier melt contribution varies across the region, but generally increases upstream (Lutz et al. 2014). Glaciers store meteoric water in the form of ice and release water in the warmer months, and are an important source of water in drier regions and seasons (Kaser et al. 2010). Changes in glaciers might also increase risks, especially from glacial lake outburst floods (Richardson and Reynolds 2000; Sect. 7.4).

This section introduces existing methods to measure glacier area and estimate their volume and then provides a synthesis of glacier changes throughout the extended $\mathrm{HKH}$, followed by a summary of projected future change.

\subsubsection{Measuring Glacier Change}

Our knowledge of glacier changes in the extended $\mathrm{HKH}$ has increased substantially in recent years and a number of studies provide an overview of the changes in the region (Bolch et al. 2012; Kääb et al. 2012; Yao et al. 2012; Gardner et al. 2013; Brun et al. 2017). Glacier fluctuations are not only a reaction to climatic forcing (Leysinger Vieli and Gudmundsson 2004; Oerlemans 2005; Leclercq and Oerlemans 2012; Lüthi et al. 2015; Hewitt 2005): glacier responses are also affected by topographic features such as the length, area, glacier surface slope, glacier bedrock slope, and surroundings (e.g., proglacial lake, type of bedrock sediment), supraglacial features (debris-cover, lakes, ice cliffs, and so on), subglacial hydrology, and surge dynamics (in the case of surge-type glaciers). As a result, changes in glacier length and area through advance or retreat are an indirect, delayed, and filtered signal to changes in climate. In contrast, the glacier mass balance (i.e., the annual change in volume or mass) is a relatively direct and undelayed response to the annual atmospheric conditions (Haeberli and Hoelzle 1995).

Comparison of glacier outlines obtained from different periods in time, usually from remote sensing data, allows quantification of glacier length and area changes (Paul et al. 2004; Shangguan et al. 2007; Bolch et al. 2010a; Bhambri et al. 2011). Area changes of debris-covered glaciers need special consideration as glaciers with thick debris-cover typically exhibit lower rates of shrinkage than debris-free glaciers (Scherler et al. 2011; Nuimura et al. 2012; Pieczonka and Bolch 2015).

Glacier mass changes can be measured in the field and by remote sensing. In situ measurements consist of ablation measurements with ablation stakes and accumulation measurements using snow pits (Kaser et al. 2003). The results of these measurements are then extrapolated to the entire glacier (Hock and Jensen 1999), with glacier-wide errors of typically 
$0.30 \mathrm{~m}$ w.e./yr if the measurement locations are well distributed over the entire glacier (Wagnon et al. 2013). In situ measurements provide detailed information but are laborious and can therefore only be obtained for relatively few glaciers. As reported by Vincent et al. (2013) and Gardner et al. (2013) glaciological mass balance data may be negatively biased due to poor spatial sampling. For this reason, we exclude data sets that have known errors from our analysis.

A widely-used approach to estimate glacier volume change and subsequently the mass change is the geodetic approach, or the difference in surface elevation measured at two or more points in time (Finsterwalder 1954; Bamber and Rivera 2007; Berthier et al. 2007; Bolch et al. 2010a). The major advantage of the geodetic approach is that large regions can be investigated simultaneously, but it is constrained by the availability of suitable elevation data or imagery. A global comparison of direct and geodetic mass balance measurements yields root mean square errors of approximately $0.4 \mathrm{~m}$ w.e./yr (Cogley 2009).

The Gravity Recovery and Climate Experiment (GRACE) programme has provided additional estimates of glacier mass loss or gain in the extended HKH region through analysis of changes in the earth's gravity field. Though gravimetric changes do not only depend on glacier mass changes (e.g., Reager et al. 2016), GRACE data provide useful insights on the interannual variability of mass balance (e.g., Yi and Sun 2014). However, large interannual variability in the gravity signal for the extended HKH region results in large uncertainties in mass loss estimates: $-4 \pm 20$ Gt over the period 2003-2010 (Jacob et al. 2012).

Modelling provides a final avenue for examining glacier mass change. For a detailed discussion on glacier mass balance models and limitations, see Sect. 7.3.4 (Glacier projections).

\subsubsection{Glacier Area}

Knowledge about glacier cover is crucial, but only since the release in 2012 of the first Randolph Glacier Inventory (RGI, www.glims.org/rgi) (Arendt et al. 2012; Pfeffer et al. 2014) has a complete inventory of glaciers in the entire extended HKH region been freely available. Earlier information about glacier coverage exists, but the quality varies and the data is often not available in digital format.

Prior to the satellite era, information about glacier area was based on manual delineation from aerial photography or topographic maps. Freely available satellite imagery has greatly facilitated glacier mapping. This is especially true for the satellites which also provide short wave infrared acquisitions (such as Landsat TM, launched in 1984), as this wavelength allows automated identification of clean ice and snow (Paul et al. 2002). Automated classifications of debris-covered ice and seasonal snow on glacier-free areas are more difficult, and manual adjustments are needed to improve the quality. Current inventories are based solely on manual delineations (Nuimura et al. 2015) or on automated classification with manual post-processing (Bajracharya and Shrestha 2011; Frey et al. 2012). Satellite images also allow the identification of moraines from the Little Ice Age (LIA) and thus provide information on the LIA extent of glaciers (Baumann et al. 2009; Loibl and Lehmkuhl 2014). Uncertainties in glacier inventories result mainly from the resolution of the selected images, their quality with respect to snow and cloud cover, the existence of cast shadows, and the presence of debris cover (Paul et al. 2013).

Publicly available glacier inventories now exist for the entire High Mountain Asia (HMA) region (GAMDAM inventory, Nuimura et al. 2015), as well as larger subregions such as NW India (Frey et al. 2012), China (Guo et al. 2015), eastern Himalaya (Nagai et al. 2016; Ojha et al. 2017), and the whole of Hindu Kush-Karakoram-Himalaya (Bajracharya and Shrestha 2011). Recent inventories still contain significant differences in area; these can arise from different methodological approaches, difficulties such as snow and cloud cover on available satellite scenes, the treatment of debris-covered glaciers, and, in particular, different definitions of the glaciers. For example, GAMDAM (Nuimura et al. 2015) largely omitted ice on steep headwalls, while these areas are included in Frey et al. (2012). The available recent estimates of glacier area for the entire extended HKH (Table 7.1) vary from $\sim 76,580 \mathrm{~km}^{2}$ (GAMDAM, Nuimura et al. 2015) to $81,140 \mathrm{~km}^{2}$ (RGI5.0, Arendt et al. 2015).

Table 7.1 Recent estimates of glacier area and volume for the extended $\mathrm{HKH}$ region

\begin{tabular}{|c|c|c|c|c|}
\hline Himalaya $^{a}$ & Karakoram $^{\mathrm{b}}$ & Pamir $^{\mathrm{c}}$ & Tibetan-Plateau $^{\mathrm{d}}$ & References \\
\hline \multicolumn{5}{|c|}{ Glacierized area $\left(\mathrm{km}^{2}\right)$} \\
\hline 21,973 & 21,205 & NA & NA & $\begin{array}{l}\text { Cogley } \\
(2011)\end{array}$ \\
\hline 22,829 & 17,946 & NA & NA & $\begin{array}{l}\text { Bolch et al. } \\
\text { (2012) }\end{array}$ \\
\hline 19,991 & 18,563 & 10,403 & 27,622 & $\begin{array}{l}\text { Nuimura } \\
\text { et al. (2015) }\end{array}$ \\
\hline NA & NA & NA & 31,573 & $\begin{array}{l}\text { Guo et al. } \\
(2015)\end{array}$ \\
\hline 26,688 & 19,962 & 13,071 & 39,822 & RGI 3.2 \\
\hline 20,070 & 21,475 & 10,681 & 28,912 & RGI 5.0 \\
\hline \multicolumn{5}{|c|}{ Ice volume $\left(\mathrm{km}^{3}\right)$} \\
\hline 1,212 & 1,683 & NA & NA & $\begin{array}{l}\text { Huss and } \\
\text { Farinotti } \\
(2012)\end{array}$ \\
\hline 1,297 & 1,869 & NA & NA & $\begin{array}{l}\text { Frey et al. } \\
\text { (2014) }\end{array}$ \\
\hline
\end{tabular}

${ }^{\mathrm{a}}$ Regions $10-12$

${ }^{\mathrm{b}}$ Region 9

${ }^{\mathrm{c}}$ Regions 6-7

${ }^{\mathrm{d}}$ Regions $13-22$ as defined in Fig. 7.1

$\mathrm{NA}=$ not available 
Between 10 and $25 \%$ of the total glacierized area in the Karakoram and Himalayan ranges is debris-covered (Scherler et al. 2011; Bajracharya and Shrestha 2011). In the upper Indus basin $\sim 18 \%$ of the total glacier area is debris-covered (Khan et al. 2015); in the Ganges basin this is $\sim 14 \%$, and in the Brahmaputra basin this is $\sim 12 \%$ (Bajracharya and Shrestha 2011). Lower topographic relief, and, on average, lower glacier ablation rates, limit the number of debris-covered glaciers on the TP.

Surging glaciers exhibit recurrent periods of elevated flow velocity (or surges) at rates of one to two orders of magnitude greater than during their periods of inactivity (or quiescence). Surging glaciers are especially common in the Karakoram (Copland et al. 2011; Paul 2015) and Pamir (Kotlyakov et al. 2008), but also occur in western Kunlun (Hewitt 2007; Kotlyakov et al. 2008; Hewitt 2011; Quincey et al. 2011; Sevestre and Benn 2015). The cause of glacial surging in the extended HKH region is largely unknown, although links have been made to climate, internal dynamics, and subglacial hydrology (Yasuda and Furuya 2013, 2015). Analyses of glacier change should distinguish carefully between surging and non-surging glaciers, as surging glaciers will exhibit patterns of length, area, and elevation changes that are inconsistent with those of nearby non-surging glaciers.

\subsubsection{Glacier Volume}

There are essentially two different methods to estimate glacier volume: (1) volume-area scaling approaches (Bahr et al. 1997; Cogley 2011), where ice volume is calculated based on an empirical formula in relation to the glacier area, as larger glaciers tend to be thicker; and (2) distributed estimates of glacier thickness (Huss and Farinotti 2012; Linsbauer et al. 2012; Farinotti et al. 2017). Empirical volume-area scaling approaches are potentially strongly misleading and inappropriate, particularly for the composite glaciers found in the extended HKH region, and we caution against their use in estimating glacier volumes. Distributed approaches are based on the assumption that ice thickness can be related to glacier slope, flow velocity, and basal shear stress. Freely available surface elevation data can thus be used to estimate current and future glacier thicknesses and bed topographies. All methods of ice volume estimation tend to have large uncertainties (Frey et al. 2014; Farinotti et al. 2017) and are calibrated to the limited number of existing thickness measurements (Gärtner-Roer et al. 2014).

Depending on the inventory and method used, total glacier volumes are estimated to range between 3,000 and $4,700 \mathrm{~km}^{3}$ (Table 7.1) (Frey et al. 2014). According to these available estimates, the volume of glacier ice in the Karakoram is likely to be larger than the volume in the Himalaya.

\subsubsection{In Situ Mass Balance Measurements and Reference Glaciers}

International organizations such as the United Nations (UN) and the International Council for Science (ICSU) recommend the collection of detailed, direct, and long-term standardized measurements of seasonal glacier mass changes. To bridge the gap between detailed process studies and global coverage, field-based glacier measurements should be combined with observations of glacier length change, geodetic mass balance, meteorology, and streamflow variations. And ideally, these measurements should be representative of a particular region (International Hydrological Decade 1970; Fountain et al. 2009). Monitoring and reporting agencies for glacier mass balance include the World Glacier Monitoring Service (WGMS) as part of the Global Terrestrial Network for Glaciers (GTN-G) within the Global Climate Observing System (GCOS), both of which follow guidelines set out by Haeberli et al. (2007).

Although measurements should be representative of a region, glaciers are usually chosen for detailed measurement based on logistical constraints rather than representation. Glaciers with mass balance observations tend to be located in accessible regions at lower elevation ranges. This, in addition to the difficulties involved in accessing accumulation areas (Vincent et al. 2013), may lead to negatively biased mass balance measurements (Fujita and Nuimura 2011). There are only three sets of long-term ( $>30$ years) in situ mass balance measurements in all of High Mountain Asia - in the Pamir-Alay (Abramov Glacier) and Tien Shan (Urumqi Glacier No. 1 and Tuyuksu Glacier). Despite the large area of ice cover in the extended $\mathrm{HKH}$, there are no long-term measurements available from anywhere in the region. In total, only about 30 glaciers, covering an area of less than $120 \mathrm{~km}^{2}$ out of the total glacierized area of 80 $100,000 \mathrm{~km}^{2}$, have had direct glaciological measurements made for one or more years.

Several mass balance studies were initiated in the extended HKH in the 1970s but were discontinued after some years. Direct mass balance measurements were made on only four glaciers during the 1990s (AX010, Rikha Samba, Kangwure, and Dokriani). These measurements were either short ( $<5$ years) or discontinuous (e.g., Dokriani Glacier) and provide an incomplete picture of glacier change. The longest time series of in situ mass balance measurements in the extended HKH is that for the Xiao Dongkemdi Glacier on the Tibetan Plateau, where measurements started in 1989. The longest mass balance time series in the Himalaya is Chhota Shigri, where measurements started in 2002 (Table 7.2). There are several other glaciers in the extended HKH which have published data for several years of investigations, are still being investigated, and/or have been selected for continuous measurement. 
Table 7.2 Glaciers with 5 or more years of in situ mass balance data where measurements are still ongoing

\begin{tabular}{|c|c|c|c|c|c|c|}
\hline Glacier name & Region & Country & Latitude & Longitude & $\begin{array}{l}\text { Measurement } \\
\text { period(s) }\end{array}$ & Sources \\
\hline Chhota Shigri & Lahaul-Spiti & India & $32^{\circ} 28^{\prime} \mathrm{N}$ & $77^{\circ} 52^{\prime} \mathrm{E}$ & Since 2002 & Azam et al. (2016); WGMS \\
\hline Phuche Glacier & Ladakh & India & $34^{\circ} 16^{\prime} \mathrm{N}$ & $77^{\circ} 33^{\prime} \mathrm{E}$ & Since 2010 & Thayyen et al. (2015) \\
\hline Rikha Samba & Hidden Valley & Nepal & $28^{\circ} 50^{\prime} \mathrm{N}$ & $83^{\circ} 30^{\prime} \mathrm{E}$ & $\begin{array}{l}\text { 1998-1999 } \\
\text { Since } 2011\end{array}$ & Fujita and Nuimura (2011); WGMS \\
\hline Yala & $\begin{array}{l}\text { Langtang } \\
\text { Valley }\end{array}$ & Nepal & $28^{\circ} 14^{\prime} \mathrm{N}$ & $85^{\circ} 36^{\prime} \mathrm{E}$ & $\begin{array}{l}\text { 1996, } 1998 \\
\text { Since } 2011\end{array}$ & $\begin{array}{l}\text { Fujita and Nuimura (2011), Baral et al. (2014); } \\
\text { WGMS }\end{array}$ \\
\hline Mera & Dudh Koshi & Nepal & $27^{\circ} 43^{\prime} \mathrm{N}$ & $86^{\circ} 52^{\prime} \mathrm{E}$ & Since 2007 & $\begin{array}{l}\text { Wagnon et al. (2013), Sherpa et al. (2017); } \\
\text { WGMS }\end{array}$ \\
\hline Pokalde & Dudh Koshi & Nepal & $27^{\circ} 55^{\prime} \mathrm{N}$ & $86^{\circ} 50^{\prime} \mathrm{E}$ & Since 2009 & $\begin{array}{l}\text { Wagnon et al. (2013), Sherpa et al. (2017); } \\
\text { WGMS }\end{array}$ \\
\hline West Changri Nup & Dudh Koshi & Nepal & $28.0^{\circ} \mathrm{N}$ & $86.8^{\circ} \mathrm{E}$ & Since 2010 & Sherpa et al. 2017; WGMS \\
\hline Qiyi & Qilian Shan & China & $39^{\circ} 15^{\prime} \mathrm{N}$ & $97^{\circ} 45^{\prime} \mathrm{E}$ & $\begin{array}{l}1975-1977 \\
1984-1988 \\
2002-2003 \\
\text { Since } 2006\end{array}$ & Yao et al. (2012) \\
\hline Xiao Dongkemadi & Tanggula Shan & China & $33^{\circ} 10^{\prime} \mathrm{N}$ & $92^{\circ} 08^{\prime \prime} \mathrm{E}$ & Since 1989 & Fujita et al. (2000), Yao et al. (2012); WGMS \\
\hline Parlung Glacier No. 94 & SE-Tibet & China & $29^{\circ} 23^{\prime} \mathrm{N}$ & $96^{\circ} 59^{\prime}$ & Since 2006 & Yao et al. (2012); WGMS \\
\hline
\end{tabular}

Table 7.2 shows all glaciers with measurements for more than five years which have an ongoing measurement programme. We refer to the Supplementary Table S7.1 for all available measurements.

\subsubsection{Observed Changes}

\subsubsection{Hindu Kush-Himalaya-Karakoram}

Since the mid-18th century, glaciers in the extended HKH have been, on average, in retreat (Iwata 1976; Mayewski and Jeschke 1979; Bräuning 2006). A regional increase in the number of glaciers that were stationary or advancing was observed between 1920 and 1940, with the maximum advance of most Karakoram glaciers observed in 1940 (Mayewski and Jeschke 1979).

Since the 1950s, only reductions in glacier area (or shrinkage) have been observed (Fig. 7.4). Based on a compilation of area change studies, eastern Himalaya glaciers have tended to shrink faster than glaciers in the central or western Himalaya. A clear recession of glaciers has also been observed on the northern slopes of the Himalaya (Nie et al. 2010; Li et al. 2011; Shangguan et al. 2014; Xiang et al. 2014). Rates of area change range between $-0.1 \% / \mathrm{yr}$ for the Chandra-Bhaga basin (northwestern Indian Himalaya) between 1980 and 2010 to more than $-1.0 \% / y r$ for the Poiqu basin (on the northern slopes of central Himalaya) between 1986 and 2001. Smaller glaciers are shrinking faster on average than larger ones (Bhambri et al. 2011; Bolch et al. 2010a; Thakuri et al. 2014; Ojha et al. 2016), although the smaller glaciers of Ladakh show lower rates of retreat than other Himalayan glaciers (Schmidt and Nüsser 2012).

While glaciers in the Hindu Kush mountains have also experienced significant length reductions since 1973 (Haritashya et al. 2009; Sarikaya et al. 2012), we were unable to identify any studies that specifically examined area change in this region.

Reported shrinkage rates for the heavily debris-covered glaciers in the Khumbu Himalaya vary depending on the time window and the glaciers investigated. Reported rates of area change vary between $-0.12 \pm 0.05 \% / \mathrm{yr}$ for the period 1962-2005 (20 glaciers; Bolch et al. 2008) and $-0.27 \pm 0.06 \% / y r$ for the period 1962-2011 (29 glaciers; Thakuri et al. 2014).

In contrast to the Himalayan glaciers, a complicated picture emerges in the Karakoram, where large, often rapid, advances and retreats have occurred, more or less out of phase with one another (Hewitt 2011; Bhambri et al. 2013; Paul 2015). On average, glacier areas in the Karakoram have not changed significantly (Bhambri et al. 2013; Minora et al. 2016; Fig. 7.4). Individual glaciers, however, have shown large area increases or decreases due to surge behaviour, while non-surge-type glaciers were relatively stable over the last decade. Given the context of glacier retreat throughout the rest of the extended HKH region, this behaviour has been designated the 'Karakoram anomaly' (Hewitt 2005). In contrast, Liu et al. (2006) reported a significant area loss at a rate of $-0.13 \% / y r$ over the period $1968-1999$ for glaciers on the north slope of the Karakoram in the Yarkand Basin. 


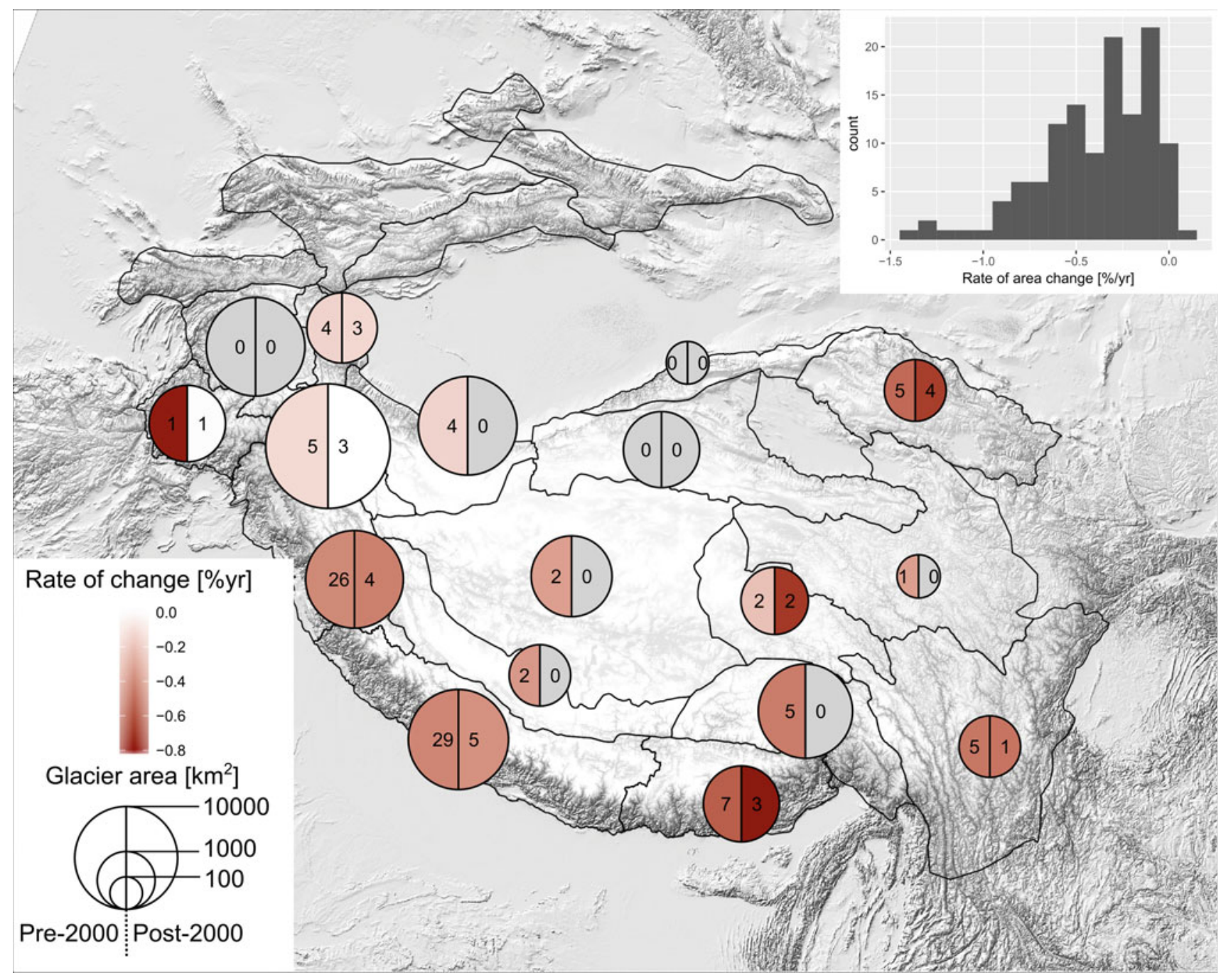

Fig. 7.4 Glacier area change rates $(\% / y r)$ for different regions in the extended HKH. Pre-2000 and post-2000 means are given by the colour in the left and right half-circles, respectively, together with the number

However, recent information about mass changes did not show significant differences between the northern and southern slopes (Kääb et al. 2015; Brun et al. 2017); there are no data available at the present date on area changes after 2000.

Trends in glacier area change vary across the extended HKH region. Aggregated trends (Fig. 7.4; Table 7.3) are not area weighted, and may not agree with individual studies due to sampling bias. Over the past six decades, average rates of area change have increased in the western and eastern Himalaya, and remained constant or decreased in the central Himalaya (Fig. 7.4; Table 7.3). Individual studies, in contrast, show increased area losses in the central Himalaya (Bolch et al. 2008; Bhambri et al. 2011; Thakuri et al. 2014) and decreased losses in the upper Indus basin in Ladakh and Ravi basin, both in the western Himalaya (Schmidt and Nüsser 2012; Chand and Sharma 2015). Area loss has led to of studies available for each period. Circle diameter is scaled to the current glacierized area in each region. A histogram of all observed change rates is given in the upper right

greater supraglacial debris cover in the Himalaya (Bolch et al. 2008; Schmidt and Nüsser 2009; Kamp et al. 2011; Nuimura et al. 2012; Thakuri et al. 2014), while debris-covered area has remained constant in the Karakoram (Herreid et al. 2015). Area loss also leads to glacier fragmentation; the number of glaciers in the Himalaya is reported to have increased over the past five decades (Bhambri et al. 2011).

\section{Mass Changes}

Glaciers in the extended HKH show mass loss since at least the 1970s (Fig. 7.5). Individual rates of mass change and uncertainty estimates for each study and region are given in Supplementary Table S7.2. ICESat (Ice, Cloud, and land Elevation Satellite) laser altimetry and DEM (Digital Elevation Model) differencing revealed an average mass loss of $-0.2 \mathrm{~m}$ w.e./yr for the first decade of the $21 \mathrm{st}$ century 
Table 7.3 Average glacier mass and area change in the extended HKH for different regions and time periods, with number of studies in parentheses. Averages are calculated from all study types (geodetic, glaciological, modelled) (See Supplementary Tables S7.1 and S7.2 for details.)

\begin{tabular}{|c|c|c|c|c|c|}
\hline \multirow[t]{2}{*}{ Region ID (see Fig. 7.1) } & \multirow[t]{2}{*}{ Region } & \multicolumn{2}{|c|}{ Glacier mass balance rate ( $\mathrm{m}$ w.e./yr) } & \multicolumn{2}{|c|}{ Glacier area change rate $(\% / y r)$} \\
\hline & & $\sim 1970-2000$ & $\sim 2000-2010$ & $\sim 1970-2000$ & $\sim 2000-2010$ \\
\hline 6 & Western Pamir & - & $-0.26(2)$ & - & \\
\hline 7 & Eastern Pamir & $-0.12(2)$ & $-0.02(10)$ & $-0.13(4)$ & $-0.12(3)$ \\
\hline 8 & Hindu Kush & - & $-0.30(5)$ & $-0.79(1)$ & $+0.01(1)$ \\
\hline 9 & Karakoram & $-0.10(3)$ & $-0.06(12)$ & $-0.11(5)$ & $+0.02(3)$ \\
\hline 10 & Western Himalaya & $-0.33(5)$ & $-0.50(11)$ & $-0.38(26)$ & $-0.34(4)$ \\
\hline 11 & Central Himalaya & $-0.39(10)$ & $-0.42(14)$ & $-0.41(29)$ & $-0.37(5)$ \\
\hline 12 & Eastern Himalaya & $-0.17(1)$ & $-0.66(10)$ & $-0.55(7)$ & $-0.81(3)$ \\
\hline 13 & Western Kunlun & $-0.07(2)$ & $+0.08(9)$ & $-0.13(4)$ & - \\
\hline 14 & Eastern Kunlun & - & -0.40 & - & - \\
\hline 15 & Altun Shan & - & +0.10 & - & - \\
\hline 16 & Tibetan Interior & - & $-0.01(7)$ & $-0.32(2)$ & - \\
\hline 17 & Gangdise & - & $-0.52(2)$ & $-0.34(2)$ & - \\
\hline 18 & Nyainqentanglha & - & $-0.58(9)$ & $-0.44(5)$ & - \\
\hline 19 & Tanggula Shan & $-0.21(3)$ & $-0.29(4)$ & $-0.2(2)$ & $-0.69(2)$ \\
\hline 20 & Hengduan Shan & $-0.30(3)$ & $-0.85(6)$ & $-0.46(5)$ & $-0.47(1)$ \\
\hline 21 & Eastern Tibetan Mtns. & - & $-0.64(3)$ & $-0.32(1)$ & - \\
\hline \multirow[t]{2}{*}{22} & Qilian Shan & $-0.23(8)$ & $-0.40(6)$ & $-0.51(5)$ & $-0.66(4)$ \\
\hline & Regions 6-22 & $-0.26(41)$ & $-0.37(123)$ & $-0.35(98)$ & $-0.42(25)$ \\
\hline
\end{tabular}

(Kääb et al. 2012; Gardner et al. 2013; Gardelle et al. 2013), which is approximately half of the global average (Gardner et al. 2013; Marzeion et al. 2014) for this period. However, mass changes are not uniform but show contrasting patterns. The greatest rates of mass loss in the extended $\mathrm{HKH}$ post-2000 are found in the eastern Himalaya $(-0.6 \mathrm{~m}$ w.e./ yr) and western Himalaya ( $-0.6 \mathrm{~m}$ w.e./yr). Moderate losses are observed in the central Himalaya $(-0.4 \mathrm{~m}$ w.e./yr), and the Hindu Kush ( $-0.3 \mathrm{~m}$ w.e./yr). In contrast, glaciers in the Karakoram showed neutral mass balances or even slight mass gains after 2000 (Table 7.3).

Mass balance estimates for the period before 2000 are sparse, but the use of declassified satellite imagery for pre-2000 DEM generation is leading to increased understanding (Bolch et al. 2008; Maurer et al. 2016; Bhattacharya et al. 2016). Available studies seem to confirm that pre-2000 mass balance patterns are similar to post-2000 patterns (Table 7.3), although mass loss rates have increased in the Himalaya and the eastern Tibetan Plateau. The inferred stability of Karakoram glaciers, based on stable debris-covered areas since the 1970s (Herreid et al. 2015), has recently been confirmed by geodetic studies in the region (Bolch et al. 2017; Zhou et al. 2017). Recent publications have found that this anomaly can not only be expanded to include the eastern Pamir and the western Kunlun Shan (Holzer et al. 2015; Lin et al. 2017; Neckel et al. 2014; Wu and Zhang 2008), but also that the region of mass gain is centred at western Kunlun, while the Karakoram and Pamir are only partly affected (Kääb et al. 2015; Brun et al. 2017; see also Table 7.3, Fig. 7.5, and Sect. 7.3.3.2).

Glaciers in the Khumbu region (central Himalaya) showed a mass loss of $-0.3 \mathrm{~m}$ w.e./yr between 1970 and 2007 (Bolch et al. 2011a), while glaciers in the eastern Himalaya lost $-0.2 \mathrm{~m}$ w.e./yr for a similar period, 19742006 (Maurer et al. 2016).

Results from in situ measurements and modelling confirm the predominantly negative mass balance during the last five decades with a higher mass loss since roughly 1995 (Bolch et al. 2012). Debris-covered glaciers (Box 7.3) in the Langtang and Khumbu regions of the central Himalaya also lost mass in recent years, although at a lower rate than debris-free glaciers (Immerzeel et al. 2014; Pellicciotti et al. 2015; Shea et al. 2015b; Thompson et al. 2016; Vincent et al. 2016). However, there is evidence for a period of balanced conditions for Lahaul-Spiti. For example, Vincent et al. (2013) concluded that Chhota Shigri Glacier was on average in balance within the period 1988 to 2002, based on elevation measurements in 1988 and 2010 and in situ mass balance measurements starting 2002. Modelling studies of the Chhota Shigri (western Himalaya) and Mera (central Himalaya) glaciers also suggest a period of balanced conditions between mid-1980 and mid/late-1990 (Azam et al. 2014; Shea et al. 2015a). 


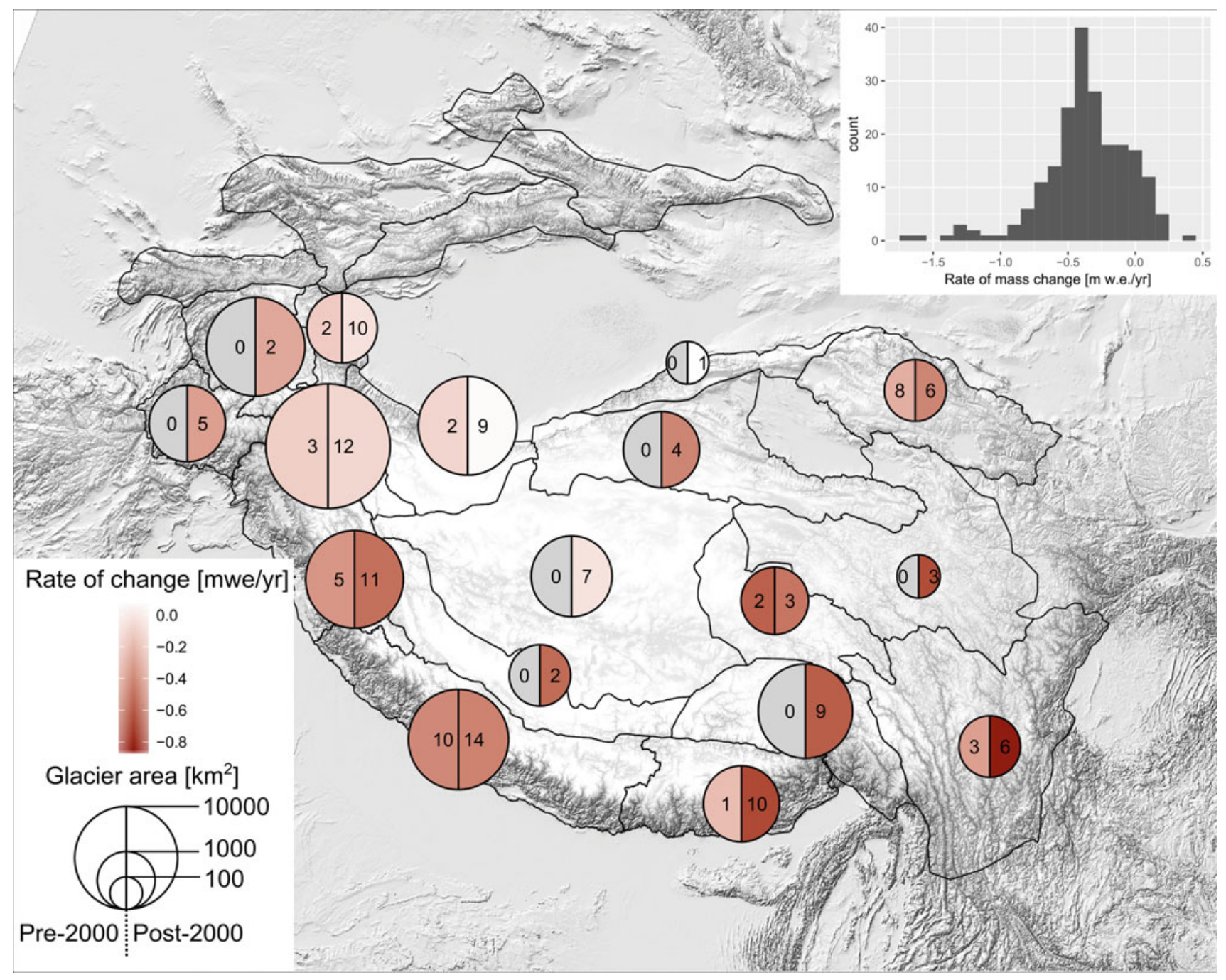

Fig. 7.5 Summary of 164 glaciological, geodetic, and modelling estimates of rates of glacier mass change ( $\mathrm{m}$ w.e./yr) by glacier region. The arithmetic average of data from all studies pre- and post-2000 is shown by the shading of half circles (pre-2000 left, post-2000 right), together with the number of studies available for each period; periods without data are coloured in grey. A histogram of all reported regional mass change rates is given in the upper right

\section{Box 7.3 Debris-covered glaciers}

Rapid weathering of high-relief glacial valleys in the extended HKH supplies a sizeable amount of rock debris onto the glaciers via rock and mixed snow/ice avalanches. This debris travels downstream with the ice flow, and as the surrounding ice melts away, it builds up as a thick layer of surface rock material in the lower part of the glacier. The debris layer acts like an insulating blanket that protects the ice beneath from melting. Yet debris-covered glaciers also contain varying concentrations of bare ice cliffs (Fig. 7.6) and supraglacial ponds. The role of ice cliffs and ponds in the overall melt rate of debris-covered glaciers was first examined by Sakai et al. (2000a, 2002) and is an active area of research. The termini of debris-covered glaciers respond slowly to climate change, the position does not change very much and a long tongue of slow-flowing debris-covered ice is preserved at the lower part of the glacier. Despite significant recent progress through remote-sensing/field measurements (Immerzeel et al. 2014) and model studies of the complex coupled system of debris, ice cliffs, and ponds (Miles et al. 2016; Buri et al. 2016; Banerjee 2017), significant challenges still remain in understanding these glaciers: we cannot yet predict the long-term changes in the debris cover area or thickness, or the effect of such changes on the future of glaciers and their meltwater production at the scale of the whole Himalaya. 


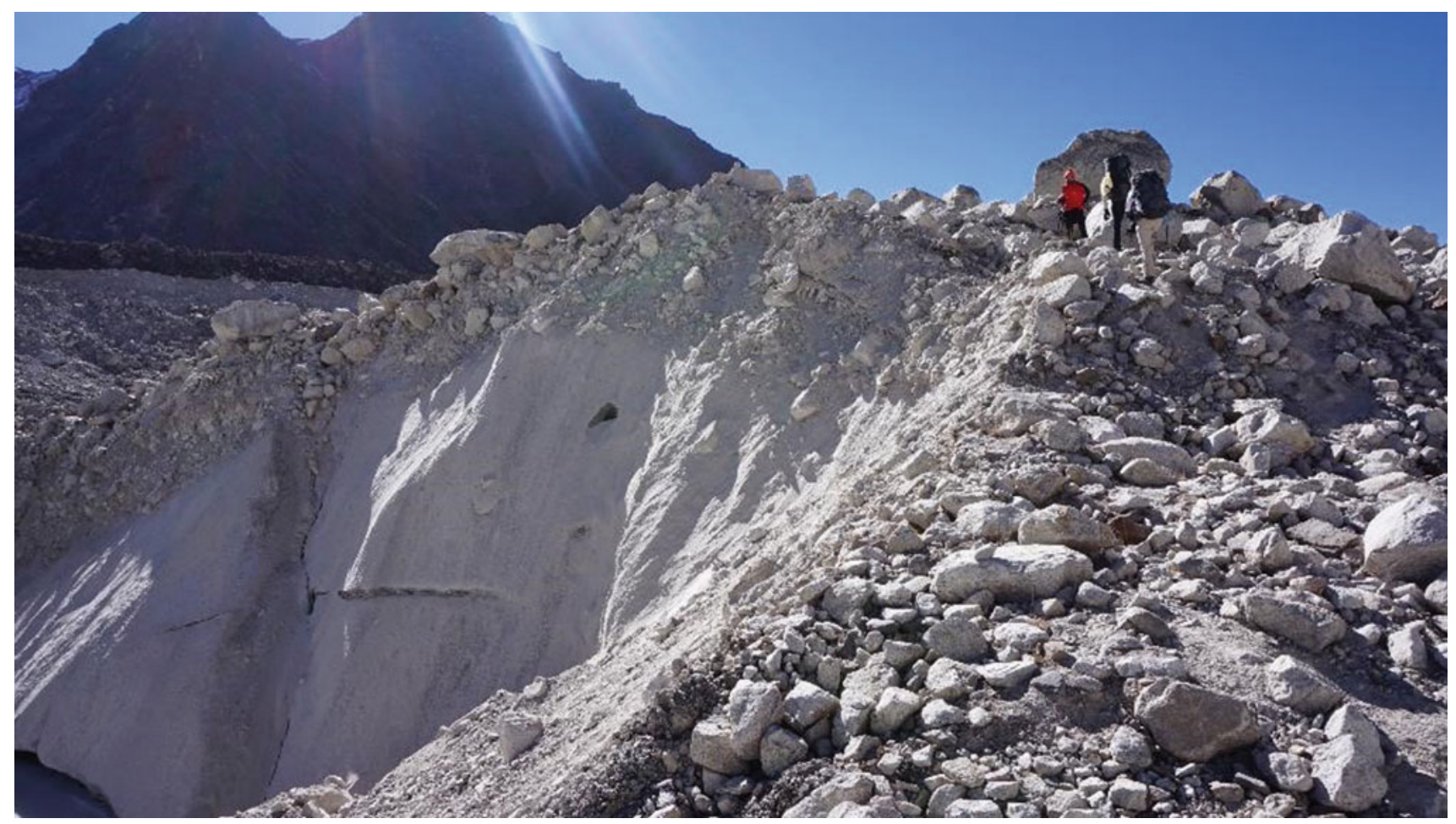

Fig. 7.6 Ice cliff on debris-covered Khumbu Glacier, Nepal Himalaya, November 2016 (photo: J. Shea)

\subsubsection{Pamir}

\section{Area and Length Changes}

Frequent surges and contrasting length changes are not only common in the Karakoram but also in central and northeast Pamir (Dolgoushin and Osipova 1975; Kotlyakov et al. 2008; Osipova and Khromova 2010; Holzer et al. 2016; Wendt et al. 2017), and a recent surge was also reported in eastern Pamir (Shangguan et al. 2016). In contrast to the Karakoram, however, existing studies on glacier area and length changes suggest a continuous area loss in northeastern and central Pamir. For example, Shchetinnikov (1993) reports an area loss of about 0.5\%/yr from 1957-60 to 197880. Published results addressing the glacier area changes during recent decades found the least negative rates of glacier retreat $(<0.1 \% / \mathrm{yr})$ in central Pamir, where the highest peaks and the largest glaciers are located, while shrinkage rates of $>0.25 \% / \mathrm{yr}$ are observed in north, west, and south Pamir (Khromova et al. 2006; Aizen and Aizen 2014; Holzer et al. 2016; Zhang et al. 2016). The area change rates in eastern Pamir appear to be consistent $(-0.13 \% / \mathrm{yr})$ for the past 30 years. In contrast, the glacier area at Muztag Ata, the highest mountain massif in the Pamir, has not changed significantly since the 1970s (Holzer et al. 2015). However, as yet there has been no detailed peer-reviewed assessment of glacier area changes in the whole of the Pamir based on consistent datasets and methodologies, and the above-mentioned values should be interpreted with care.

\section{Mass Changes}

Mass change estimates in the Pamir vary depending on the region under consideration. Gardelle et al. (2013) report slight mass gain $(+0.16 \pm 0.14 \mathrm{~m}$ w.e./yr) for central Pamir (2000 to 2010) based on DEM differencing, but Kääb et al. (2015) found significant mass loss between 2003 and 2008 $(-0.48 \pm 0.14 \mathrm{~m}$ w.e./yr) based on ICESat laser altimetry data. Recalculated mass loss estimates for the regional definitions shown above (Fig. 7.1) based on the data by Kääb et al. (2015) show strong mass loss in western Pamir $(-0.44 \pm 0.10 \mathrm{~m}$ w.e./yr $)$ and balanced conditions in the east $(-0.02 \pm 0.25 \mathrm{~m}$ w.e./yr). Gardner et al. (2013) reported mass loss of $-0.11 \pm 0.19 \mathrm{~m}$ w.e./yr, assuming an average density of $850 \mathrm{~kg} \mathrm{~m}^{-3}$. A recent geodetic estimate based on optical stereo data for 2000 to 2016 gave a slightly negative mass budget of $-0.08 \pm 0.06 \mathrm{~m}$ w.e./yr in western Pamir and a possible positive budget of $+0.07 \pm 0.10 \mathrm{~m}$ 
w.e./yr in eastern Pamir (Brun et al. 2017). Similar results were published by Lin et al. (2017) for 2000-2014 based on TerraSAR-X/TanDEM-X and SRTM data $(-0.11 \pm 0.07 \mathrm{~m}$ w.e./yr for western and $+0.12 \pm 0.07 \mathrm{~m}$ w.e./yr for eastern Pamir). As the above studies investigate different time periods, the temporal variability in mass changes will lead to varying estimates of rates of mass change. The most detailed investigations are available for the Fedchenko glacier, by far the largest glacier in Pamir (Lambrecht et al. 2014). The glacier experienced only a slight mass loss of $0.07 \mathrm{~km}^{3}$ w.e./ yr (specific mass loss <0.001 m w.e./yr) between 1928 and 2000 , with about $75 \%$ of the loss occurring during the second half of the 20th century. Differences in mass loss estimates based on the same dataset can be attributed to the regional aggregation, the assumptions for SRTM radar beam penetration into snow and ice, and the time period analysed.

In situ measurements and modelling results for the Abramov Glacier in Pamir-Alay, north of the Pamir mountains (Fig. 7.1), reveal clear mass loss since the beginning of the measurements in the 1960s. Reanalysis of available in situ data from 1971-94 found an average mass balance of $-0.46 \pm 0.06 \mathrm{~m}$ w.e./yr; modelled mass balances of $-0.51 \pm 0.17 \mathrm{~m}$ w.e./yr were obtained for 2000-2011 (Zemp et al. 2015; Barandun et al. 2015). These results contrast with Gardelle et al. (2013) who found no significant mass changes for the same glacier based on the geodetic method. A geodetic study of Muztag Ata glaciers revealed, on average, balanced conditions since 1973 (Holzer et al. 2015). This agrees with in situ measurements of a small glacier in this mountain massif where in situ measurements from 2005-2014 showed an average value of $+0.10 \mathrm{~m}$ w.e./ yr (Holzer et al. 2015).

From the available studies and data, we conclude that glaciers in western Pamir experienced a moderate mass loss, while glaciers in eastern Pamir were in balance or had only slight mass losses for several decades.

\subsubsection{Tibetan Plateau}

\section{Area Changes}

Compilations of area changes for over 3,100 glaciers in western China since the Little Ice Age maximum (Wang 1991; Liu et al. 2000, 2003; Wang and Ding 2002; Su and Shi 2002) indicate that glaciers in western China have lost a total area of $\sim 16,000 \mathrm{~km}^{2}$, or $\sim 27 \%$, to the middle of the 20 th century (1950s through the 1980s) (Liu et al. 2006). Glacial shrinkage exhibits a regional pattern, with smaller area change rates $(-21 \%)$ in the inner region of the Tibetan Plateau and higher rates $(-47.7 \%)$ in the upper Indus river basin located in China. Remote sensing analyses for SE Tibet show similar rates of area loss $(-27 \%)$ since the LIA maximum (Loibl and Lehmkuhl 2014). A complete loss of glaciers less than $0.6 \mathrm{~km}$ in length was observed in Bugyai Kangri, in the southeast Tanggula Range (Wang and Ding 2002).

Glacier area changes on the TP have been calculated at a range of scales: river basins (Wei et al. 2014; Wang et al. 2015a), mountain ranges (Bolch et al. 2010b; Sun et al. 2015), and mountain sections/parts (Jiang et al. 2013; Tian et al. 2014). First maps are based on photogrammetry (Liu et al. 2016) and extend through the Landsat data acquired after the mid-1970s (Nie et al. 2010; Wang et al. 2012). A clear recession of glaciers has been observed since the 1950s/1970s/1980s in western Hengduan Shan (Liu et al. 2016), the A'Nyêmaqên Range in the Yellow River source area (Wang et al. 2015b; Liu et al. 2002), and the Qilian mountains (Sun et al. 2015), with annual shrinkage rates of approximately $-0.5 \% / y r$.

Glaciers in the western Kunlun (north-eastern Tibetan Plateau) have been on average relatively stable (Fig. 7.4), an eastern continuation of the stable conditions observed in the eastern Pamir and Karakoram. A recent study investigating the changes of the debris-free parts of the glaciers of entire extended HKH region for the period $\sim 1976$ until 2013 is in general in line with previous findings with highest area loss in south-eastern and the lowest in the in the north-eastern Tibetan Plateau (Ye et al. 2017). The combination of advancing and retreating glaciers has resulted in a negligible change in glacier area during 1970-2001 and 1990-2011 in the latter region. (Shangguan et al. 2007; Li et al. 2013; Bao et al. 2015). Four glaciers have been recognized as surging during 2003 and 2011 (Yasuda and Furuya 2013). Surging glaciers have also been found in the central Kunlun Mountains (Guo et al. 2013) and the Purogangri Ice Cap in central Tibet (Neckel et al. 2013). The retreat of small glaciers and glaciers with lower median elevations has resulted in the complete loss of some of the small glaciers and the disintegration of larger glaciers into two or more smaller glaciers (Meiping et al. 2015).

Glaciers in different mountain ranges show varying responses. The available data on glacier area changes in western Kunlun (Bao et al. 2015), Mount Geladandong (Wang et al. 2013a, b) and Bugyai Kangri in the Tanggula range (Liu et al. 2016), Mount Tuanjie in the Qilian Mountains (Xu et al. 2013), and Mount Gongga (Pan et al. 2012) show that the decadal trend in glacier area change differs for each mountain range (Fig. 7.2).

\section{Mass Changes}

Region-wide mass balance estimates are available for the period after 2000 from remote sensing methods, mainly 
based on ICESat laser altimetry data for the period 2003 to 2009, but also on DEM differencing (Table 7.3, Fig. 7.5). While the studies deviate in absolute numbers, they agree on general trends. The most negative mass balances are found in southeast TP (East Nyainqentanglha), while balanced budgets or even positive mass balances are reported for the western Kunlun Shan (Li et al. 2011; Zhang et al. 2012; Neckel et al. 2014; Brun et al. 2017). Results for glaciers in inner or central Tibet slightly deviate: while Neckel et al. (2014) report possible slight mass gains for 2003-2009, Brun et al. (2017) report slight mass losses for 2000-2016.

This general pattern is supported by in situ measurements (Yao et al. 2012): a strongly negative mass balance $(-0.9 \mathrm{~m}$ w.e./yr for 2006-2014) is reported for Parlung glacier No. 94 in Hengduan Shan, and a less negative mass balance (-0.6 m w.e./yr, for 2006-2010) for Xiaodongkemadi glacier in Tanggula Shan. A mass balance of $-0.5 \mathrm{~m}$ w.e./yr was observed for Qiyi Glacier in Qilian Shan.

Observed mass balance data prior to 2000 is available for only a few glaciers (Qiyi, Meikuang, Xiaodongkemadi, and Kangwure). Observed and simulated mass balance data for individual glaciers and regions/sub-regions also show a distinctive pattern (Fig. 7.5). Mass balances of glaciers in Qilian Shan, eastern/western Kunlun Shan, and Tanggula Shan were near zero (or positive) until the early 1990s, and then became increasingly negative over time. Glacier mass changes in the Hengduan Shan have fluctuated dramatically since 1960 and have been increasingly lower than values in other regions since 2000. Positive mass balances observed from geodetic studies in western Kunlun Shan in 2006-2010 contradict modelled negative mass balances. There is a conflict between the mass balance in western Kunlun Shan during 2006-2010 (positive, obtained by DEMs) and the area change as shown in Fig. 7.4 (negative, simulated). Essentially, the former is more convincing as all geodetic studies (using DEMs and/or ICESat data) reveal positive balances (Supplementary Table S7.2).In addition, it needs to be considered that area changes in the highly continental mountain ranges might show a strongly delayed signal due to long response times to climate forcing.

\subsubsection{Glacier Projections}

Changes in temperature and precipitation affect seasonal snowpacks, equilibrium line altitudes, glacier mass balances, and volume at annual timescales, and glacier area and length in the long term. Projections of future glacier change typically combine mass balance models, estimates of future temperature and precipitation change, and physically-based or empirical snow and ice melt models. The challenges in modelling glacier change are substantial, in particular for debris-covered glaciers.
Projections of future glacier change in the region have been done at regional scale (Marzeion et al. 2012; Giesen and Oerlemans 2013; Radić et al. 2014; Zhao et al. 2014; Huss and Hock 2015; Kraaijenbrink et al. 2017), at catchment scale (Shea et al. 2015b; Soncini et al. 2015, 2016), and at the scale of individual glaciers (Naito et al. 2000; Adhikari and Huybrechts 2009; Rowan et al. 2015).

Recent projections typically use a number of different climate scenarios (e.g., RCP4.5 and RCP8.5) and thus a range of volume change estimates and a multi-model mean can be used to assess the climate-based uncertainty (Wiltshire 2014). Structural uncertainty, or the uncertainty related to how simplified models can capture the wide range of processes and physics that determine glacier evolution, is more difficult to assess. Most modelling studies parametrize ice flow either through volume length (or area) scaling or through slightly more advanced approaches. However, to accurately understand the interaction between glaciers and climate, fully coupled ice flow models are required that explicitly simulate the ice transport from the accumulation areas to the ablation tongues. In the extended HKH, only a few studies exist that make a first attempt to do this (Miller et al. 2012; Rowan et al. 2015; Shea et al. 2015b). A third level of uncertainty is derived from the initial glacier volume conditions, which are largely unknown as measurements are very scarce and existing estimates deviate significantly (Frey et al. 2014).

Projections of mass balance alone are insufficient for the purpose of examining future glacier change. Glaciers respond to climate change by reducing (or expanding) their area and volume. Glacier-wide mass balances are a function of glacier area, and projections that do not account for glacier dynamics will tend towards increasingly negative (and unrealistic) values. In response to increased equilibrium line altitudes and melt rates and decreased snow accumulation totals, mass balances throughout the region are projected to be increasingly negative for static geometries (Chaturvedi et al. 2014; Kulkarni et al. 2016).

\subsubsection{Near-Term Glacier Change (2030)}

In the near term, glaciers in the extended HKH are projected to see increased volume loss, though some scenarios and ensemble members show limited volume change (Figs. 7.7, 7.8). Regional scale studies show volume losses between -9 and $-32 \%$ by 2030 under moderate warming scenarios (RCP4.5), and between -8.7 and $-26.1 \%$ for higher-emission scenarios (RCP8.5) (Giesen and Oerlemans 2013; Marzeion et al. 2012; Radić et al. 2014). While overall rates of loss are similar between the emission scenarios, climate model variability can lead to greater mass loss for the lower emission scenarios in the near term.

Glacier-specific studies that explicitly incorporate debris-cover feedbacks show much more conservative 


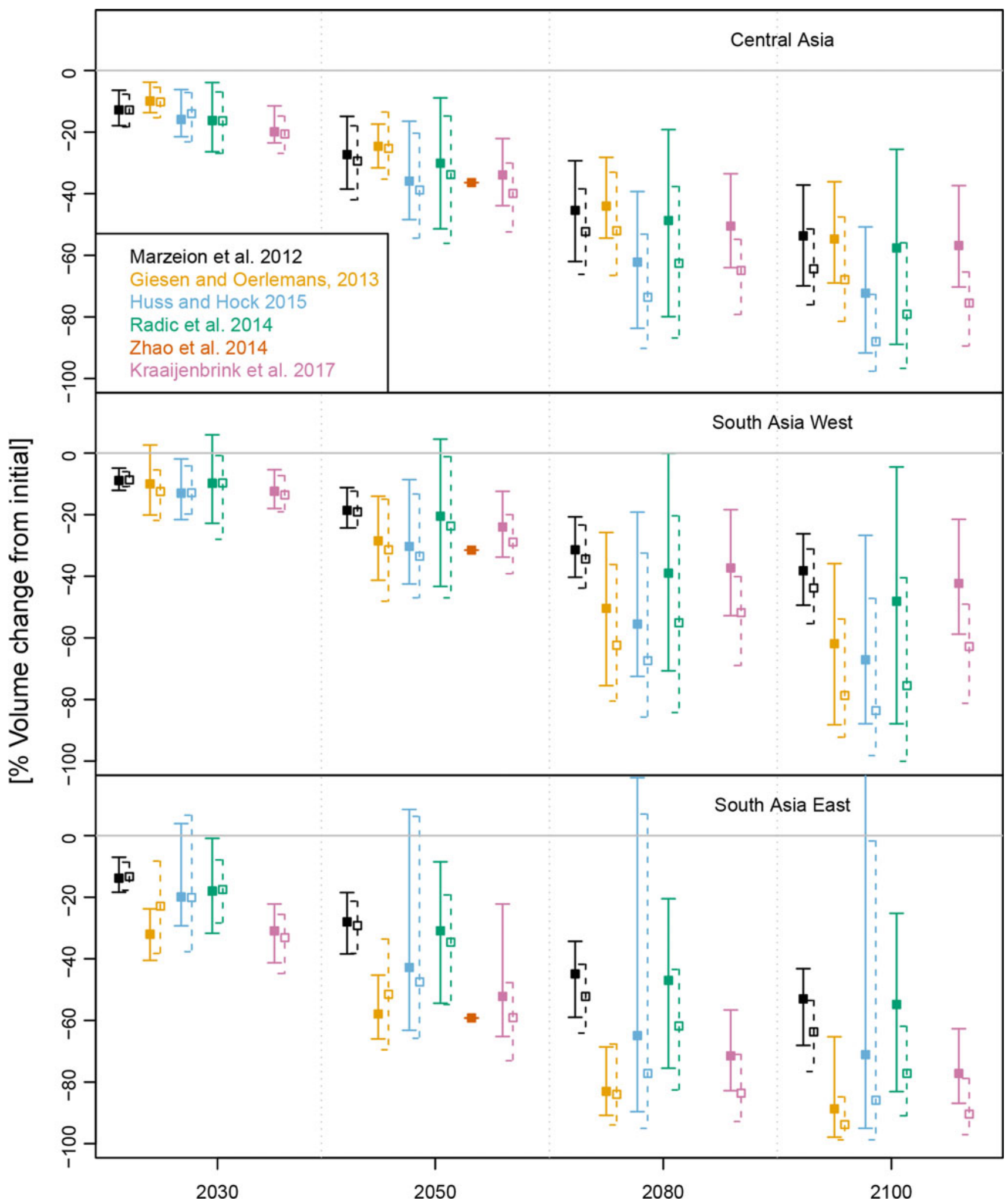

Fig. 7.7 Regional glacier volume change projections for RGI regions 13 (Central Asia), 14 (South Asia West), and 15 (South Asia East). Error bars show mean and range of multiple climate simulations for 2030, 2050, 2080, and 2100. Solid lines show results from RCP4.5 scenarios and dashed lines from RCP8.5 scenarios. Sources Marzeion et al. (2012), Giesen and Oerlemans (2013), Radić et al. (2014), Zhao et al. (2014), Huss and Hock (2015), Kraaijenbrink et al. (2017). See Supplementary Table S7.3 for details 


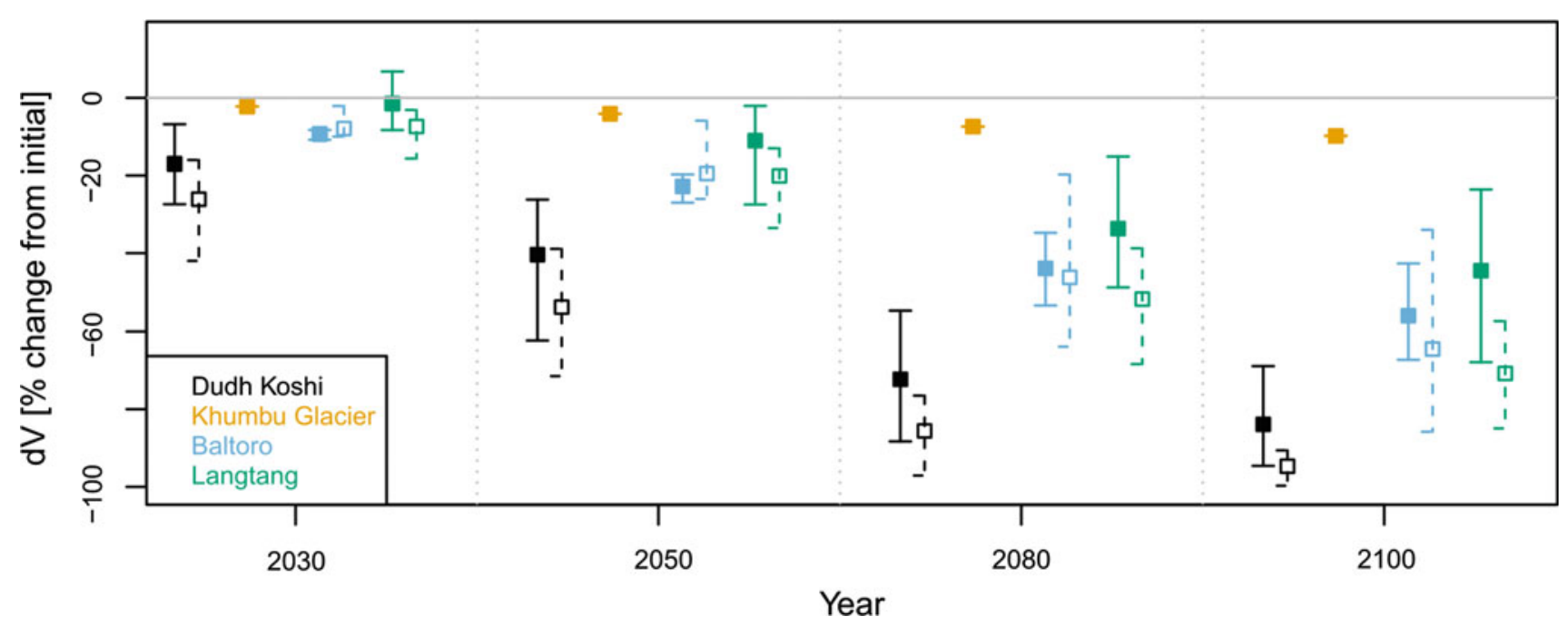

Fig. 7.8 Volume change projections for basins and glaciers in extended HKH. Symbols and error bars show mean and range of multiple climate simulations for 2030, 2050, 2080, and 2100. Solid

reductions in glacier volumes; for example, $-2.2 \%$ for the Khumbu Glacier by 2030 (Rowan et al. 2015). Basin-scale studies in the Khumbu valley (Shea et al. 2015b; Soncini et al. 2016) show greater rates of near-term volume loss that are also in line with regional estimates (Fig. 7.8).

\subsubsection{Medium-Term Glacier Change (2050)}

By mid-century, differences in the climate forcing (e.g., RCP4.5 vs RCP8.5) begin to show in the different glacier volume projections. Rates of mass loss appear to be higher in the eastern Himalaya, although again the spread in projections highlights the strong uncertainty in climate futures. For the RGI region Central Asia which includes the Pamir and the Tibetan Plateau, ensemble mean glacier volume change ranges between -24.6 and $-35.9 \%$ for RCP4.5 and -25.3 and $-38.8 \%$ for RCP8.5. RGI region South Asia (West), which includes the Karakoram region, could see volume reductions between -18.6 and $-30.3 \%$ (RCP4.5) and -19.1 and $-35.9 \%$ (RCP8.5). Eastern portions of the extended HKH could lose between one quarter and one half of their current glacier volume by 2050 .

Mid-century projections of glacier change also begin to diverge regionally. Volume declines projected for the Karakoram region begin to accelerate mid-century (Immerzeel et al. 2013; Li et al. 2016), and similar patterns are observed for west Kunlun (Kraaijenbrink et al. 2017). Other regions show sustained rates of mass loss (Rupper et al. 2012). This contrast is consistent with observations of recent mass loss in most extended HKH regions and anomalous mass gains (or steady states) in west Kunlun, Karakoram, and eastern Pamir (e.g., Sec 7.3.3). Under future temperature rise, the mass gains of these anomalous regions cannot be sustained and volume declines commence as a result (Fig. 7.9). lines show RCP4.5 and dashed lines RCP8.5 scenarios, where reported. Sources Baltoro and Langtang (Immerzeel et al. 2013), Khumbu (Rowan et al. 2015), Dudh Koshi (Shea et al. 2015b)

\subsubsection{Long-Term Glacier Change (2080 and 2100)}

Projected end-of-century changes in ice volume are pronounced in all regions. A modelling study in the Pamir projects a loss of approximately $45 \%$ by 2100 (Ohara et al. 2014), while the most negative scenarios in the eastern Himalaya point towards a near-total loss of glaciers $(-63.7$ to $-94.7 \%$ ). Losses of a similar order of magnitude are expected in regions with predominantly small, sensitive glacier tongues, such as the inner Tibetan Plateau and the Qilian Shan. As several studies have noted, these volume decreases are large in part because of the distribution of glaciers in the region and the lack of large high-elevation accumulation plateaus (Shea et al. 2015b). Relative mass losses in the Karakoram and West Kunlun Shan ( 35\% under RCP4.5 scenarios) are limited compared to other regions in the extended HKH (Kraaijenbrink et al. 2017); this is a function of the current and projected mass balance rates, the existing ice volumes, and the regional climatic differences. Projected absolute ice losses in these regions are still large and relevant for sea-level rise, as the existing ice volumes in the region comprise a large portion of the total ice volume in extended HKH. Even if warming can be limited to the ambitious target of $+1.5^{\circ} \mathrm{C}$, volume losses of more than one-third are projected for extended HKH glaciers, with more than half of glacier ice lost in the eastern Himalaya (Kraaijenbrink et al. 2017).

Equilibrium line altitudes in High Asia are projected to increase by up to $800 \mathrm{~m}$ by $2100(8.8 \mathrm{~m} / \mathrm{yr}$, Fig. 7.10$)$, depending on future emission scenarios (Huss and Hock 2015). Similar rates of ELA increase $(8-12 \mathrm{~m} / \mathrm{yr}$ ) are projected for the Everest region under high emission scenarios (Shea et al. 2015b). Glacier tongues covered by thick debris 


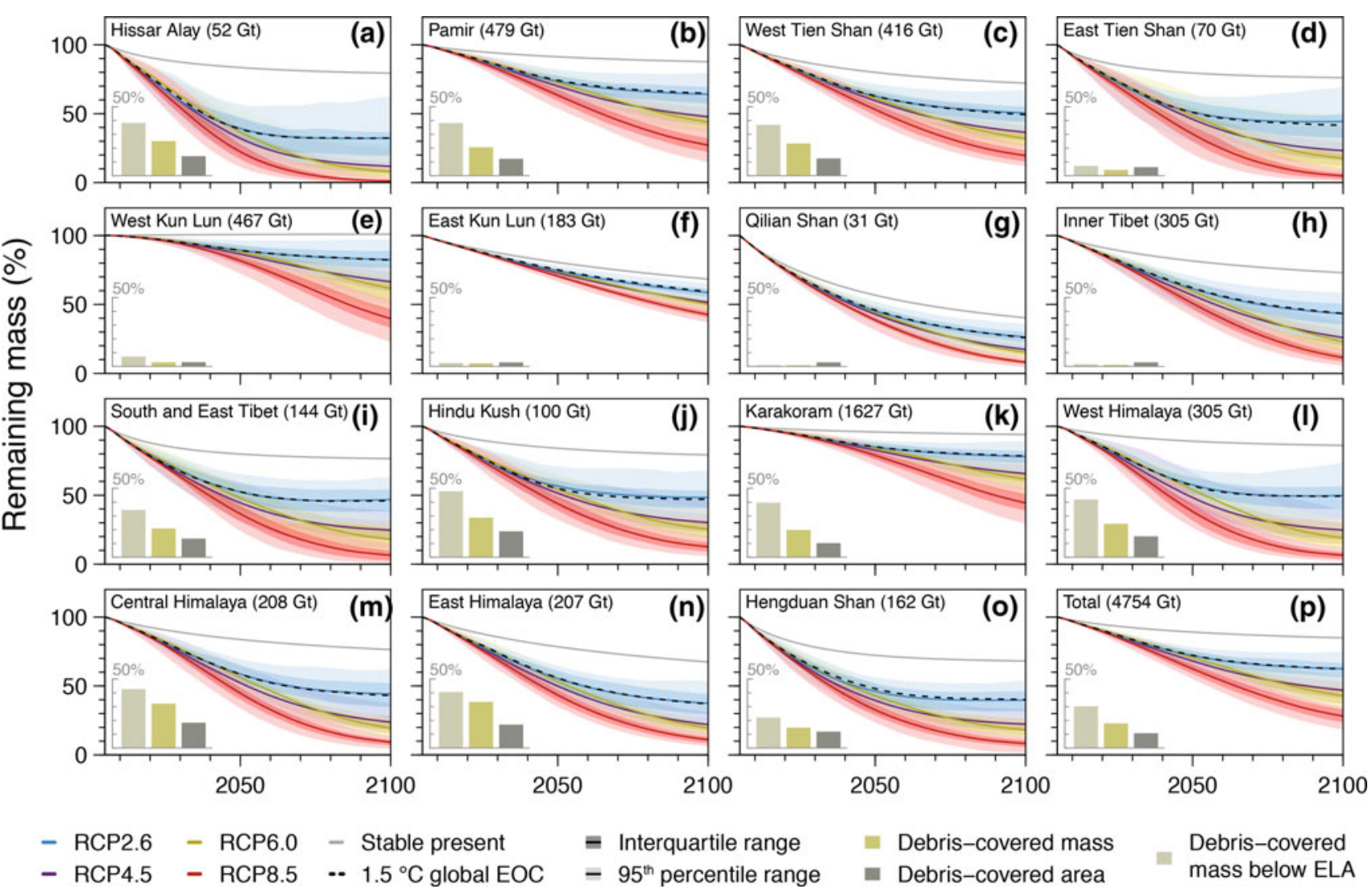

Fig. 7.9 Mass change projections and prevalence of debris cover for all RGI sub-regions (a-o) that are encompassed by the RGI regions 13 (Central Asia), 14 (South Asia West), and 15 (South Asia East). Panel p shows the projections aggregated over the entire region. Mass loss projections are shown for all four RCP scenarios, for a stable present-day climate experiment, as well as for a selection of six

which are insulated from melt, are expected to separate from their accumulation areas as the greatest melt rates occur immediately above debris-covered zones (Naito et al. 2000; Rowan et al. 2015; Shea et al. 2015b; Soncini et al. 2016). These changes will result in unsustainable negative mass balances, and will lead to the gradual disappearance of lower elevation glaciers.

\subsubsection{Recommendations}

The general agreement between our compilations of glacier change studies (cf. Figs. 7.4 and 7.5) and the regional mass change studies (e.g., Gardner et al. 2013; Gardelle et al. 2013; Neckel et al. 2014; Kääb et al. 2015; Brun et al. 2017) supports the utility of glacier and basin scale area and mass change studies. To improve our understanding of glacier climate models that have a temperature rise of $1.5^{\circ} \mathrm{C}$ at the end of the century. The error bands indicate both climate model uncertainty and glacier model parameter variability. The bar charts denote the relative abundance of debris cover in each sub-region (Source Kraaijenbrink et al. 2017)

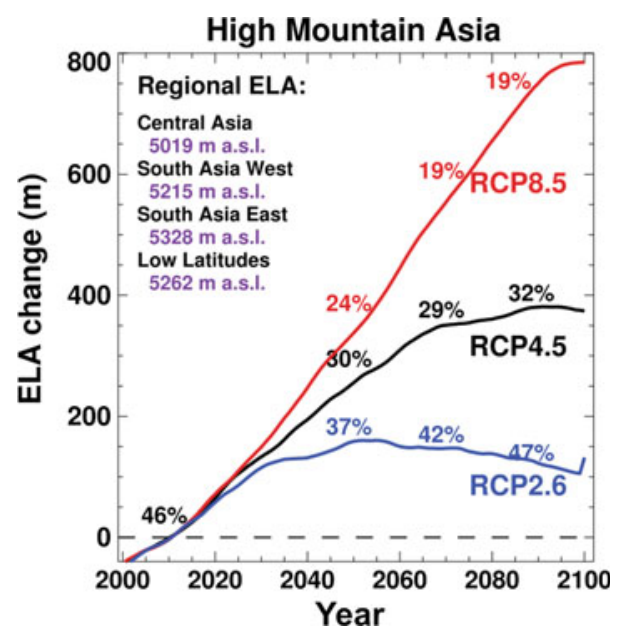

Fig. 7.10 Changes in equilibrium line altitudes (ELAs) for RGI regions in high mountain Asia relative to 2010 for three emission scenarios (Source Huss and Hock 2015) 
change in the region and reduce uncertainty in future projections, we recommend the following:

- Develop estimates of glacier mass change prior to 2000, which are currently missing in many regions, using declassified stereo imagery

- Collect field-based measurements of glacier thickness and debris thickness (e.g. by ground-penetrating radar (GPR)) in representative glacier regions to evaluate glacier volume estimates and debris cover characteristics

- Develop and test physically based and empirical models of debris-covered glacier melt components that include heat conduction through debris, ice cliff backwasting, and supraglacial ponds, and scale up to larger glacierized regions

- Develop fully coupled ice flow models taking debris sources, transport and deposition into account

- Model intercomparison projects to assess different sources of uncertainty: initial conditions, forcing data, and model structures.

\subsection{Glacial Lakes}

Glacial lakes are lakes that are fed by glacier meltwater. This can include lakes on top of glaciers (supra-glacial), lakes in front of glaciers (pro-glacial), and glacier-fed lakes that are disconnected from glaciers but close to glacier termini. In contrast, non-glacier-fed lakes have no glacier in their watershed and are fed only from precipitation and snow meltwater.

Supra-glacial lakes are often ephemeral and drain when they connect to the englacial drainage system ('perched lakes' after Benn et al. 2001). However, if there is no developed englacial drainage system or the lakes reach the glacier bed, supra-glacial lakes can grow and coalesce; when these water bodies collect behind the terminal moraine they form pro-glacial lakes ('base-level lakes' after Benn et al. 2001). Such glacial lakes usually form and grow concomitant with glacier recession, but ice-dammed lakes can also form when a surging glacier blocks a river valley (Hewitt and Liu 2010). Pro-glacial lakes pose a serious risk when the moraine (or glacier) dam fails and the water drains catastrophically as a glacial lake outburst flood or GLOF. Such events can have significant and long-lasting human and physical impacts (Richardson and Reynolds 2000; Hewitt and Liu 2010). With degrading high-mountain permafrost (see Sect. 7.5) there is also an increasing probability of rock ice/avalanches from steep slopes reaching glacial lakes and triggering GLOF events (Haeberli et al. 2016). In this section we present the current state of knowledge on the occurrence of glacial lakes and their past and projected changes.

\subsubsection{Occurrence}

An inventory of glacier-fed lakes that was manually mapped based on Landsat satellite imagery found 4,260 lakes (with an area $>0.003 \mathrm{~km}^{2}$ ) covering a total area of $557 \mathrm{~km}^{2}$ in 2010 (Zhang et al. 2015a, b, Fig. 7.11). However, a recent inventory for the same region based on Landsat 8 OLI data from 2014 revealed more than 8200 glacial lakes and an overall lake area of more than $830 \mathrm{~km}^{2}$ (Chen et al. 2017). Differences may be explained by the different data sets and investigated periods, different methods, but also the difficulty to identify turbid and ice covered lakes and lakes in shadow. However the existing studies agree that the majority of glacial lakes are distributed in the extended HKH. Lakes in the TP are on average larger and are mainly located in the interior TP (Zhang et al. 2013).

\subsubsection{Observed Change}

Change analysis of glacier-fed lakes in the extended HKH region using Landsat TM/ETM + satellite data for three periods $(1990,2000$, and 2010) showed a clear increase both in number $(3,350$ to 3,641 to 4,260$)$ and area $(440.2$ to 467.6 to $556.9 \mathrm{~km}^{2}$ (Zhang et al. 2015a, b). This study showed further that (1) small lakes $\left(<0.2 \mathrm{~km}^{2}\right)$ are more sensitive to climate change; (2) lakes closer to glaciers and at higher elevations, particularly those connected to glacier termini, have undergone greater changes in area; and (3) glacier-fed lakes are dominant in both number and area $(>70 \%)$ and exhibit faster expansion trends compared to non-glacier-fed lakes. Similar results were observed by Ashraf et al. (2017), for the western Himalaya/Karakoram/Hindu Kush region. The total increase in glacier-fed lake area for the entire extended HKH was greatest in the central and eastern Himalaya, and only one region (Nyainqentanghla) exhibited a decrease in glacier-fed lake area (Zhang et al. 2015a, b; Table 7.4).

A study conducted by ICIMOD in 2011 identified 1466 'glacial lakes' in Nepal, it included supraglacial and moraine-dammed lakes only (ICIMOD 2011). In contrast, for the same region Ives et al. (2010) found 2323 glacial lakes in 2001, which suggests a decrease in the number of glacial lakes. A closer reading suggests that the 2001 inventory number is based in part on survey data from the 1950s and 1960s. Differences in datasets and methodology for glacial lake identification are problematic when evaluating changes in glacial lake area and number. Several studies with consistent datasets and methods have subsequently found increasing glacial lake areas and numbers in most regions of the extended HKH (Gardelle et al. 2011; Mergili et al. 2013).

More critically, a subset of glacial lakes have been identified as critical or potentially dangerous based on 


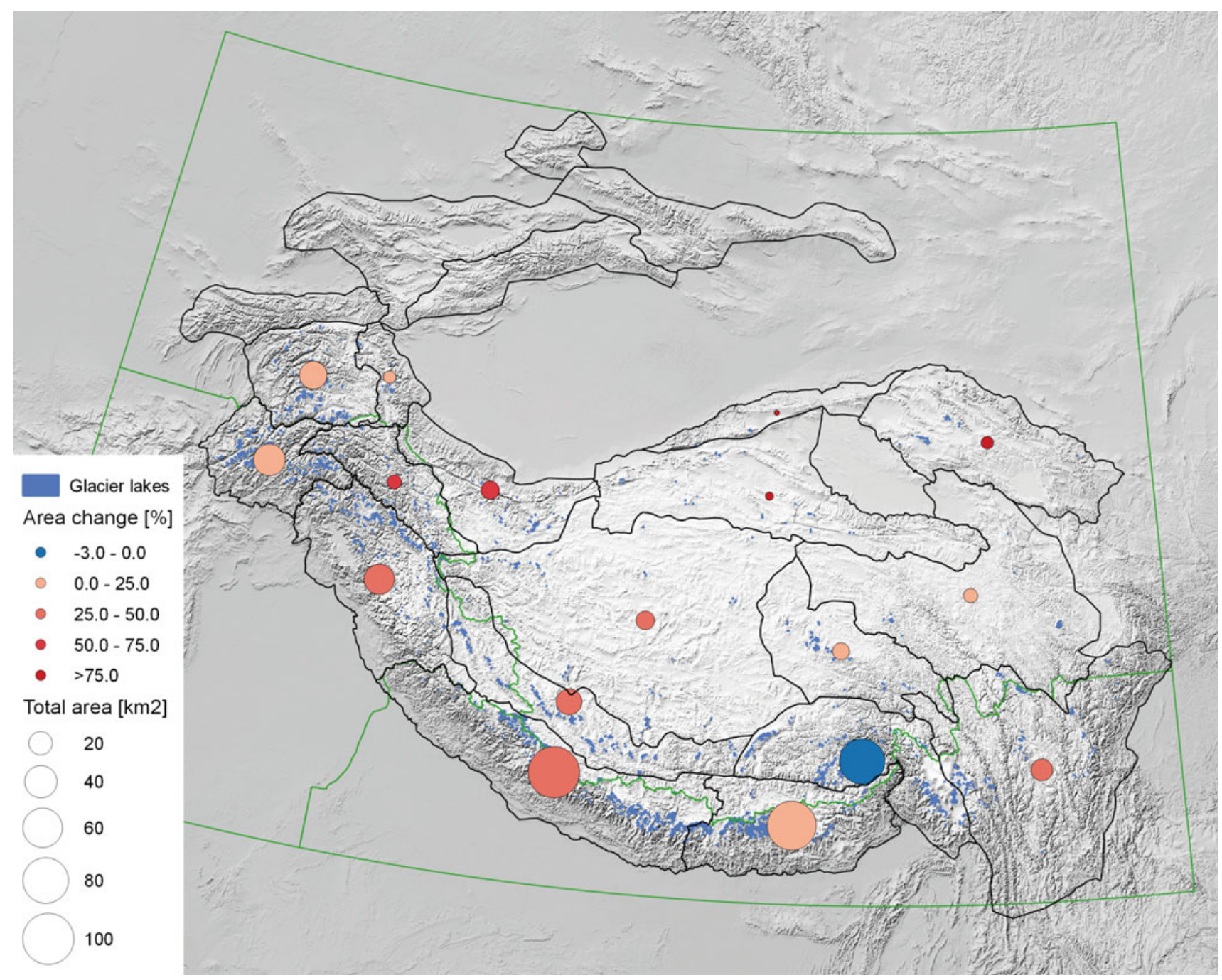

Fig. 7.11 Distribution and total area (centroid size) of ice-contact and glacier-fed lakes in the extended $\mathrm{HKH}$, and percentage change in total lake area between 1990 and 2010 (centroid colour) (data source Zhang et al. 2015a, b). Only one region has experienced a decline in glacier lake area (blue, Nyainqentanghla region)

Historical records indicate that 33 GLOF events occurred in the Himalaya before 2000 (Richardson and Reynolds 2000). The most severe disaster, the 1981 Cirenmaco GLOF, destroyed the China-Nepal Friendship Bridge and killed 200 people (Wang et al. 2015). The inventory of glacial lakes from Zhang et al. (2015a, b) serves as a basis for further analyses of priority lake and hazard assessments.

\subsubsection{Projections}

To our knowledge, few quantitative studies of glacial lake development exist. However, using simplified physically-based models, the locations of overdeepening and potential future lakes can potentially be predicted (e.g., Linsbauer et al. 2016), and it is generally expected that

existing lakes will further grow and new lakes will develop unclear if the frequency of GLOF events is on the rise.

The number of glacial lakes identified as 'potentially dangerous' has increased (Richardson and Reynolds 2000; Bolch et al. 2008; Ives et al. 2010; Liu et al. 2013), but it is 
Table 7.4 Number and area of glacier-fed lakes in 1990, 2000, and 2010 (Zhang et al. 2015a, b)

\begin{tabular}{|c|c|c|c|c|c|c|c|}
\hline \multirow{2}{*}{$\begin{array}{l}\text { Region ID } \\
\text { (see Fig. 7.1) }\end{array}$} & \multirow[t]{2}{*}{ Region name } & \multicolumn{2}{|l|}{1990} & \multicolumn{2}{|l|}{2000} & \multicolumn{2}{|l|}{2010} \\
\hline & & Number & Area $\left(\mathrm{km}^{2}\right)$ & Number & Area $\left(\mathrm{km}^{2}\right)$ & Number & Area $\left(\mathrm{km}^{2}\right)$ \\
\hline 6 & Western Pamir & 220 & 26.4 & 244 & 29.0 & 265 & 32.8 \\
\hline 7 & Eastern Pamir & 21 & 3.7 & 26 & 4.1 & 28 & 4.4 \\
\hline 8 & Eastern Hindu Kush & 333 & 32.8 & 384 & 38.6 & 393 & 39.8 \\
\hline 9 & Karakoram & 40 & 5.7 & 55 & 5.8 & 77 & 9.6 \\
\hline 10 & Western Himalaya & 301 & 27.6 & 379 & 35.1 & 400 & 38.8 \\
\hline 11 & Central Himalaya & 644 & 84.8 & 694 & 100.6 & 796 & 119.4 \\
\hline 12 & Eastern Himalaya & 579 & 92.4 & 606 & 91.9 & 728 & 115.9 \\
\hline 13 & Western Kunlun Shan & 53 & 11.6 & 47 & 11.4 & 71 & 17.6 \\
\hline 14 & Eastern Kunlun Shan & 15 & 0.9 & 22 & 0.9 & 38 & 2.8 \\
\hline 15 & Altun Shan & 2 & 0.03 & 7 & 0.08 & 8 & 0.16 \\
\hline 16 & Tibetan Interior Mountains & 72 & 14.7 & 89 & 11.8 & 107 & 18.9 \\
\hline 17 & Gangdise Mountains & 308 & 19.7 & 394 & 24.7 & 428 & 28.9 \\
\hline 18 & Nyainqentanglha & 511 & 93.4 & 424 & 79.3 & 544 & 90.2 \\
\hline 19 & Tanggula Shan & 57 & 9.5 & 50 & 9.4 & 78 & 11.7 \\
\hline 20 & Hengduan Shan & 152 & 17.0 & 163 & 16.7 & 242 & 24.2 \\
\hline 21 & Eastern Tibetan Mountains & 26 & 5.4 & 30 & 5.8 & 30 & 5.8 \\
\hline 22 & Qilian Shan & 21 & 0.12 & 31 & 4.0 & 32 & 4.6 \\
\hline
\end{tabular}

with ongoing glacier shrinkage. Conceptual studies show that glacial lakes will likely form where flat, crevasse-free surfaces indicate compressing flow through bed overdeepenings, followed by steeper and crevassed surfaces which indicate extending flow over bedrock riegels (e.g., Quincey et al. 2007; Frey et al. 2010; Maanya et al. 2016). These overdeepenings will be filled with water if not filled with sediment. As demonstrated by Rounce et al. (2016), the formation or growth of glacial lakes must be assessed along with changes in other objective hazards (moraine stability, mass movement exposure) for a full evaluation of glacier lake hazards. It should be noted that numerous new lakes will form with continued deglaciation (Sect. 7.3.4), and hazardous lake risk assessment should evolve continually. In combination with the glacier shrinkage and lake formation or expansion, permafrost degradation on oversteepened rock slopes will increase the probability of impact waves and far-reaching flood waves from large rock/ice avalanches (Haeberli et al. 2016; Bolch et al. 2010b).

\subsubsection{Recommendations}

Further development of hazardous lake risk assessments should incorporate projected changes in lake volume, glacier extent, extreme climatic events, and stability-related hazards, such as permafrost degradation. Repeat detailed UAV surveys of moraine-dammed glacier lakes will enable identification of small-scale changes to dam integrity.

\subsection{Permafrost}

Permafrost, like glaciers and snow cover, not only occurs at high latitudes but also in cold, high-elevation environments at lower latitudes (Haeberli et al. 2010). It is commonly defined as soil or rock remaining below $0{ }^{\circ} \mathrm{C}$ for more than two consecutive years. Besides this thermal definition, permafrost is often understood as a ground material: soil or rock that is frozen (i.e., contains ice) for a long time. The ice in the subsurface can exist in pores of rock or soil, as well as in discrete layers. When this ice melts, in response to human disturbance or environmental change, ground characteristics such as mechanical strength and hydraulic permeability undergo drastic changes as well. With seasonal changes, a surficial layer of ground undergoes freezing and thawing. In permafrost conditions, the portion of the ground that thaws during summer is termed the active layer. Because the permafrost is located beneath this layer, it is not visible at the terrain surface and its distribution and changes cannot readily be observed based on remote sensing products. For this reason, the understanding of glaciers and snow and their changes is much better developed in many regions than the understanding of permafrost. In this section, we provide background information about the permafrost research and distribution in the extended HKH, followed by a summary of the current knowledge about past changes in ground temperature and active layer thickness in permafrost-dominated 
areas. The last section outlines the limited knowledge about future trends related to permafrost.

Within the extended HKH, permafrost research has been limited mainly to the Tibetan Plateau (TP). It is mostly focused on an engineering corridor where the construction and maintenance of roads, railways, and other linear infrastructure requires detailed understanding and characterization of the permafrost environment. Some permafrost research was also conducted in the Tajik Pamir during the Soviet time (Gorbunov 1990).

Permafrost research on the TP started in the early 1960s (Wu and Zhang 2008; Zhang et al. 2008a, b). After the mid-1970s, large-scale and systematic permafrost investigations were widely conducted along the Qinghai-Tibetan Highway (Cheng and Wang 1983) and over the past two decades, numerous institutions and individual investigators have established extensive monitoring networks ( $\mathrm{Wu}$ and Zhang 2008; Zhao et al. 2010; Wu et al. 2012). Monitoring of the active layer and permafrost temperatures provides data and information for climate change studies and for infrastructure operations and maintenance. Studies investigate how changes in the active layer and permafrost impact hydrological processes, the carbon cycle, vegetation and ecosystems, geomorphological processes (such as the expansion of thermokarst, thaw lakes, or thaw slumps), and engineered infrastructures on the TP and in surrounding regions.

Outside China, there has been no systematic collection of permafrost data in the extended $\mathrm{HKH}$ region to date, and even within the TP, there has been no systematic collection in many remote mountain areas. Existing research has largely focused on local regions, such as the TP (Fort and van Vliet-Lanoe 2007; Jakob 1992; Barsch and Jakob 1998; Owen and England 1998; Regmi 2008; Hewitt 2014), western Himalaya (Fort 2003), Bhutan (Iwata et al. 2003), Pamir-Alai (Gorbunov and Titkov 1989), or systematic remote mapping of rock glaciers (Schmid et al. 2015). Further, only a few observations have been made of ground ice (Rastogi and Narayan 1999; Gruber et al. 2017) or ground temperature (Shiraiwa 1992; Klimeš and Doležal 2010) exist.

Knowledge about the distribution and characteristics of permafrost, however, is important in the extended HKH. This assessment provides an overview of relevant permafrost research in and beyond the extended HKH and infers relevant processes and impacts.

\subsubsection{Occurrence}

Due to its subterranean nature, the spatial extent of permafrost cannot be quantified using visual observations. Expert estimation (Gorbunov 1978) or computer models for generating permafrost maps are thus required to visualize where permafrost is expected to exist (Gruber 2012). Remote sensing data and products (e.g., land surface temperature) and cryogenic landforms (e.g., rock glaciers) can provide additional information about permafrost occurrence (Westermann et al. 2014; Schmid et al. 2015).

The occurrence of permafrost is strongly driven by surface climatology. Often, a mean annual air temperature (MAAT) below $-1{ }^{\circ} \mathrm{C}$ is used as a first-order identification of areas with some proportion of permafrost. Shaded locations may have permafrost at this temperature, whereas sun-exposed slopes will only have permafrost at a much lower MAAT. Naturally, MAAT decreases with increasing elevation. Aridity also influences the occurrence of permafrost. Thick winter snow cover insulates the ground from a cool atmosphere leading to higher ground temperatures than at similar locations with less snow. Thus little snow cover implies favourable conditions for permafrost. Furthermore, arid areas can have debris slopes with permafrost at MAATs where glaciers would exist in areas with more precipitation. As a consequence, the abundance of permafrost beneath debris and soil increases with aridity. Steep rock slopes shed snow and are less affected by snow and glacier cover. Accordingly, permafrost occurs similarly in steep bedrock in both arid and humid regions. As a general rule, the relative proportion of permafrost and glaciers changes with aridity, with dry landscapes usually having more permafrost than glaciers and humid landscapes having more glaciers. In the extended $\mathrm{HKH}$, these general patterns are overprinted with regional differences caused by differing seasonality and trends in temperature and precipitation; detailed maps are so far only available for parts of the TP (Ran et al. 2012).

For the Pamir, permafrost has been described down to 3,800 masl in alpine meadows, as well as lacustrine and fluvial sediments, while many dry slopes remain largely free of permafrost to above 4,300 masl (Gorbunov 1990). A number of maps exist for the TP, (Ran et al. 2012); while a recent map (Gruber 2012) indicates large areas of permafrost for the remainder of the extended HKH. This map is based on gridded climate data and established rules for estimating zones of permafrost occurrence based on MAAT. It has an approximate resolution of $1 \mathrm{~km}$ and contains some estimates of uncertainty.

A recent review for the whole extended HKH (Gruber et al. 2017) estimates the permafrost area to exceed that of glaciers in nearly all countries (Fig. 7.12). The total area of permafrost estimated across the region is $1,000,000$ (500,000-1,500,000) $\mathrm{km}^{2}$, compared to roughly $90,000 \mathrm{~km}^{2}$ covered by glaciers; without the large contribution of the Tibetan and Pamir plateaus located within China, the expected permafrost area is 95,000 (30,000-180,000) $\mathrm{km}^{2}$, and that of glaciers about $55,000 \mathrm{~km}^{2}$. 


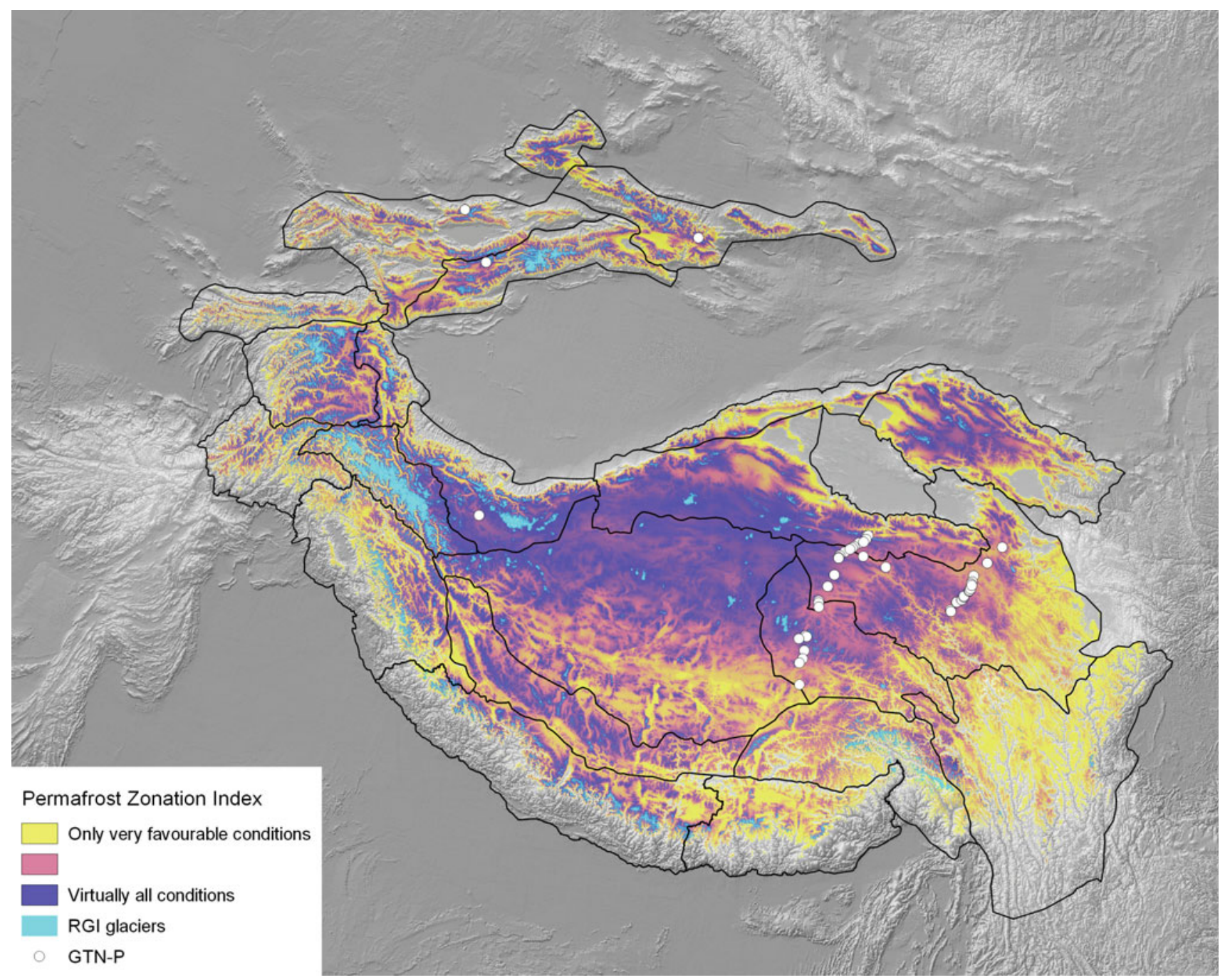

Fig. 7.12 Modelled permafrost zonation and borehole sites in the extended HKH. Boreholes listed in the GTN-P database (GTN-P 2016) are shown, but there are many more in China. The Permafrost Zonation
Index (PZI) is based on Gruber (2012), glacier outlines are from the Randolph Glacier Inventory (Pfeffer et al. 2014)

\subsubsection{Observed Change}

Observed permafrost changes have been reported for a limited number of locations, with systematic observations only available for locations on the TP and in the Tien Shan. Changes reported from the TP are good exemplars, as they mirror many cold landscapes in the extended HKH in terms of latitude, aridity, and elevation. At the same time, many regions in the extended HKH have environmental conditions (especially precipitation amounts and terrain steepness) that differ strongly from the sites for which observational data exists.

As a general trend, most permafrost in the extended HKH is likely to have undergone warming and thaw during the past decades Zhao et al. (2010). With global climate change, this is dictated by physical processes connecting the subsurface and the warming atmosphere. Consistent observations of permafrost warming and thaw in other permafrost regions worldwide corroborate this (Romanovsky et al. 2010). Finally, subsurface temperatures and the occurrence of permafrost are driven by the same energy and mass balance at the ground surface as glaciers. The loss of glacier ice, which is now documented relatively well throughout the extended HKH (Sect. 7.3; Brun et al. 2017; Bolch et al. 2012), can thus be regarded as a rough proxy indicating subsurface warming and thaw. However, it should be noted that glacier mass and permafrost changes cannot be directly related as, for example, timing and amount of snow cover can affect glaciers and ground temperatures via differing processes.

Active-layer thickness has been monitored on the TP since the early 1990s. The primary goal of these 
measurements is to support engineering infrastructure and operations. Observations show that active layer thickness increased during the period from 1995-2007 (Wu et al. 2010) to 2006-2010 (Wu et al. 2012). Often, the active layer thickness increased more for sites close to roads than for those farther away. The majority of permafrost boreholes on the TP have temperatures between 0 and $-2{ }^{\circ} \mathrm{C}$. Borehole temperatures along the Qinqhai-Tibetan Highway and railway also show an increasing trend (Wu and Zhang 2008; Zhao et al. 2010), although with locally differing magnitudes. In the Tien Shan, systematic measurements of permafrost temperature and active-layer thickness started in the 1970s. Marchenko et al. (2007) report an increase of borehole temperature of $0.3-0.6^{\circ} \mathrm{C}$ and an increase in active-layer thickness by more than $20 \%$ at the observed sites compared to the 1970s.

Overall, permafrost temperatures have increased more for cold permafrost and less or non-significantly when relatively close to the freezing point. This is because the majority of energy input into permafrost from the surface will be consumed for phase change when close to $0{ }^{\circ} \mathrm{C}$. The observed thickening of the active layer and increase of permafrost temperatures on the TP corroborates the notion of widespread permafrost degradation in the extended HKH.

Mountain slopes with thawing permafrost are expected to undergo destabilization with continued warming and thaw (e.g., Huggel et al. 2013; Krautblatter et al. 2013). This will likely cause increased probability of rock falls, landslides, or debris flows, as well as lead to unforeseen events from locations that have previously shown little mass-movement activity. These mechanisms have been shown elsewhere (Deline et al. 2015) and are expected to be equally relevant in the extended HKH region (Fort 2015; Gruber et al. 2017). Slope failures can impact infrastructure and settlements both directly and indirectly, for example when impacting glacial lakes, which are often located below or in proximity to steep slopes (Haeberli et al. 2016). Furthermore, permafrost thaw can lead to ground movement via thaw settlement, and changed geotechnical characteristics via ground-ice melt. This is important because it can lead to problems with infrastructure built in permafrost environments, which requires special attention during planning, construction, and maintenance (Doré et al. 2016; Bommer et al. 2010).

\subsubsection{Projections}

Projected climate change in the extended HKH differs among regions, along with differing regional climate and circulation regimes (see Chap. 3). Furthermore, the strong vertical climate gradients observed today are likely to cause climate change to vary with elevation. Given how little we know about the distribution and characteristics of mountain permafrost outside the TP, few detailed projections of change are available. On the TP, a reduction in permafrost area by $9-14 \%$ in 2050 and by $13-46 \%$ in 2100 has been derived from model scenarios (Nan et al. 2005). A more recent projection suggests even greater future reductions in near-surface permafrost $-39 \%$ by 2050 and $81 \%$ by 2100 accompanied by a marked increase in active layer thickness (Guo et al. 2012). While possible issues with model structure (cf. Burn and Nelson 2006; Delisle 2007) and resolution (cf. Fiddes et al. 2015) may affect the numbers presented, the trend to widespread and strong permafrost thaw is virtually certain to be robust. It is thus to be expected that strong atmospheric warming will result in active layer deepening and at least partial permafrost thaw in nearly the entire permafrost area of the extended HKH (cf. Gruber et al. 2017).

\subsubsection{Recommendations}

Increased permafrost monitoring and research in the mountainous parts of extended $\mathrm{HKH}$ is required in order to better understand possible impacts, to provide evidence of permafrost change, to enable the evaluation of numerical models, and to support the development of adaptation measures. Monitoring and research activities can be based on, and should integrate well with, ongoing efforts internationally.

\subsection{River and Lake Ice}

Information on lake and river ice has been identified as a suitable proxy for mean air temperatures and their variability. Measures of river and lake ice change include ice cover duration, as well as freeze-up and break-up dates. In line with the general temperature increase, several studies show that the average duration of lake ice occurrence has significantly decreased in the northern hemisphere during the last decades (Magnuson et al. 2000; Che et al. 2011; Dibike et al. 2011). Lake surface temperatures have also increased in the region (O’Reilly et al. 2015).

\subsubsection{Occurrence}

There are many large lakes on the Tibetan and the Pamir Plateaus which freeze in winter. The largest lakes are Selin Co, Nam Co, and Karakul Lake. However, investigations using moderate resolution remote sensing imagery (MODIS; spatial resolution of $500 \mathrm{~m}$ ) for the period 2000-2010 revealed that several of the lakes in Tibet do not freeze up completely (Kropáček et al. 2013). There are no lakes of 
similar sizes in the extended HKH, and although some studies mention the existence of lake ice (e.g. Sakai et al. 2000b), to our knowledge there are no studies addressing lake freezing and thawing in the extended HKH regions outside TP.

\subsubsection{Observed Change and Projections}

The freeze-up date and thawing dates of all larger lakes on the TP were observed over the period 2000-2010 (Fig. 7.13). They were highly heterogeneous and no clear trend could be determined in the ice cover duration during this period, even when lakes were clustered into groups with similar characteristics (both climatically and lake characteristics) (Kropáček et al. 2013). Passive microwave data for the period 1978-2013 showed a decrease in the length of ice coverage of Nam Co lake, one of the largest lakes in Tibet, by $\sim 20$ days, with freezing onset $\sim 9$ days later and thawing date $\sim 9$ days earlier (Ke et al. 2013). Similar trends were also found for Qinghai lake (Che et al. 2009).

Very few studies address changes in river ice such as changes in freeze and break-up dates and maximum ice thickness. This is probably partly due to the fact that it is difficult to make comparable measurements in mountain rivers due to water turbulence and changing river beds. No projections exist, to our knowledge. Studies of the Yellow River indicate later freeze-up dates and earlier break-up dates in the 1990s compared to the average for 1950-1990s (Xiao et al. 2007; Jiang et al. 2008). River-ice duration along the Ningxia-Inner Mongolia reach in the upper Yellow River was reduced by about seven days between 1954 and 2013 (Si et al. 2015).

\subsubsection{Recommendations}

Baseline inventories of lake freeze-up, ice cover duration, and break-up should be compiled for lakes and the large rivers in the extended $\mathrm{HKH}$ region using remote sensing products and techniques. In addition, few in-site measurement sites should be established.

\subsection{Cryosphere and Water Resources}

The mountains of the extended HKH are a source of water for more than a billion people. Climatic change in the source areas of Asia's main rivers will affect snow, glaciers, and permafrost and may potentially have a large societal impact (Immerzeel et al. 2012; Bolch 2017). The cryosphere is a key component of the hydrological cycle (Mark et al. 2015), yet the hydrology is only marginally resolved due to the intricacy of monsoon dynamics (Turner and Annamalai 2012), the poorly quantified dependence on the cryosphere (Immerzeel et al. 2010), and the physical constraints of doing research in high-elevation and generally inaccessible terrain.

Within the extended HKH, the Indus basin has the largest human dependence on snow and ice melt (Kaser et al. 2010). However, there are very large inter-basin differences in snow
Fig. 7.13 Ice cover duration of the studied lakes on the TP showing duration of ice cover represented by the total height of each bar, and duration of freeze-up period, complete ice cover, and break-up period by the heights of the respective coloured sections Source Kropáček et al. (2013)

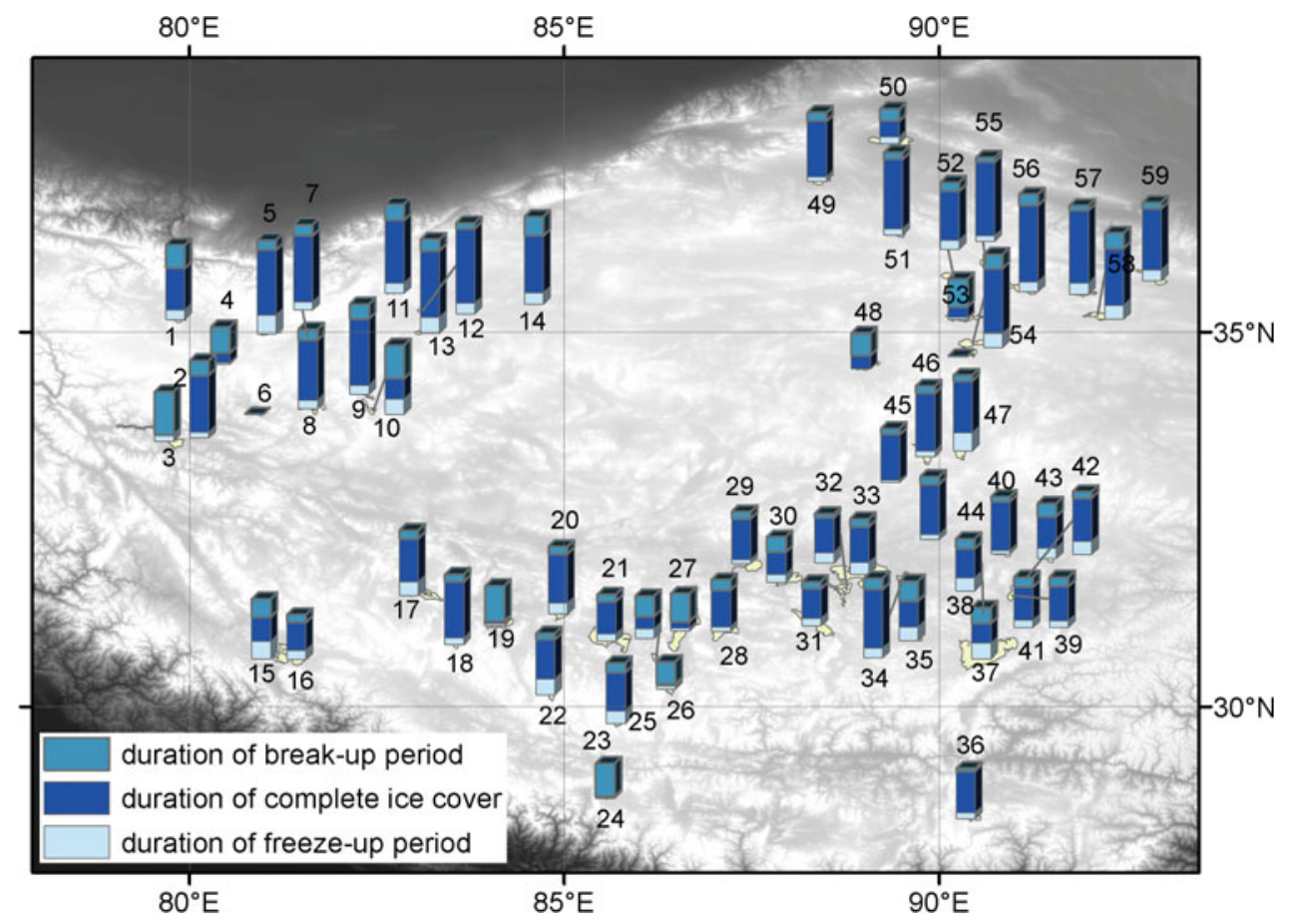


and ice contributions to streamflow (Immerzeel et al. 2010; Schaner et al. 2012; Farhan et al. 2014; Zhang et al. 2015a, b). A number of methods have been used in the extended HKH to quantify glacier contributions to streamflow (La Frenierre and Mark 2014). These include direct discharge measurements (Thayyen and Gergan 2010), hydrological modelling (Singh and Jain 2002; Nepal et al. 2013; Lutz et al. 2014; Ragettli et al. 2015), glaciological balance (Zhang et al. 2008a, b), and isotopic analyses (Racoviteanu et al. 2013; Wilson et al. 2015; Box 7.4).

However, quantitative comparisons between studies and basins are complicated by the fact that the definition of 'glacier contribution to streamflow' is inconsistent (O'Neel et al. 2014), with a key inconsistency being the way in which rain and snowmelt on top of a glacier surface is dealt with. In most cases glacier runoff is considered as the runoff from the total glacierized area, and includes all runoff leaving at the glacier terminus. This includes rain, and snow and ice melt. However, in the strict sense, only the ice which melts should be counted as glacier run-off, as rain and snowmelt would also runoff without the presence of a glacier (Radić and Hock 2014).

There is also an additional spatial dependence with regards to cryosphere contribution to streamflow: the relative importance of glacier and snowmelt runoff decreases with distance from the glaciers and snow reserves in the basin (Lutz et al. 2014; Kaser et al. 2010).

\section{Box 7.4 Determining streamflow contributions}

Despite recent studies on the hydrology of the Himalaya (Immerzeel et al. 2009, 2010; Kaser et al. 2010; Thayyen and Gergan 2010; Lutz et al. 2014), we still lack a consensus on the role of snow and ice in the hydrologic regime of Himalayan catchment basins. Our current understanding of the contribution from different sources is based primarily on modelling. However, hydrological models come in a wide range of complexities. When hydrological models are calibrated against total basin discharge, the wide range of processes and assumptions leads to a fundamental problem in hydrology: equifinality means it is possible to get the right answer for the wrong reasons (Beven 2006).

Direct measurements of hydrochemistry (including stable water isotope tracers such as $\delta^{18} \mathrm{O}$, the ration between ${ }^{18} \mathrm{O}$ and ${ }^{16} \mathrm{O}$, and impurities) have the potential to identify different sources of streamflow (snow or ice melt, rainfall, groundwater). At present, such isotope studies are scarce in the extended HKH, due to the difficulty of regularly acquiring water samples in remote terrain.
Previous extended HKH isotopic studies have identified moisture sources and atmospheric circulation patterns in Ladakh (Mayewski et al. 1983), Central Asia, and the Tibetan Plateau (Aizen et al. 1996; Garzione et al. 2000; Pande et al. 2000; Kang et al. 2002; Niu et al. 2016). In the western Himalaya (upper Indus basin), stable water isotope measurements were used together with historical hydrological records for river discharge to assess water balance in the basin (Karim and Veizer 2002). Only small watershed-scale studies have been conducted.on the southern slopes of the Himalaya, (Zhang et al. 2001; Racoviteanu et al. 2013; Wilson et al. 2015; Williams et al. 2016).

Differences in the hydrochemistry of melt from debris-free and debris-covered glaciers (Garzione et al. 2000; Williams et al. 2016) may also lead to improved estimates of melt contributions from debris-covered glaciers. Field campaigns for water isotope studies that are currently emerging in different regions of the extended HKH (Williams et al. 2013; Jeelani et al. 2016; Rai et al. 2016) will provide new opportunities for a full understanding of water source contributions to river discharge and regional climate in this area (Fig. 7.14).

\subsubsection{Observations}

As detailed snow information is lacking and difficult to obtain (Miller et al. 2012), the main focus in the extended $\mathrm{HKH}$ has historically been glacier change and its long-term impact on catchment hydrology (Singh and Bengtsson 2005; Yao et al. 2007; Akhtar et al. 2008; Kehrwald et al. 2008; Xu et al. 2009). However, recent modelling studies have shifted to include a focus on snow (Lutz et al. 2014; Tahir et al. 2016; Wulf et al. 2016), as it is an important component of the annual water budget (Archer 2003; Stewart 2009; Bookhagen and Burbank 2010) and will be affected by climate change in the near term. The role of permafrost in mountain hydrology, particularly in the extended $\mathrm{HKH}$, is largely unknown.

Sufficiently long time series are required to identify changes and trends in cryospheric and hydrological components, but these are rarely available for river discharge. Interannual variability in both meteorological conditions and total catchment or basin discharge is also possibly greater than any climate change signal (Forsythe et al. 2014). While there is confidence in field-based or remotely-sensed observations of cryospheric change, discharge measurements in remote 


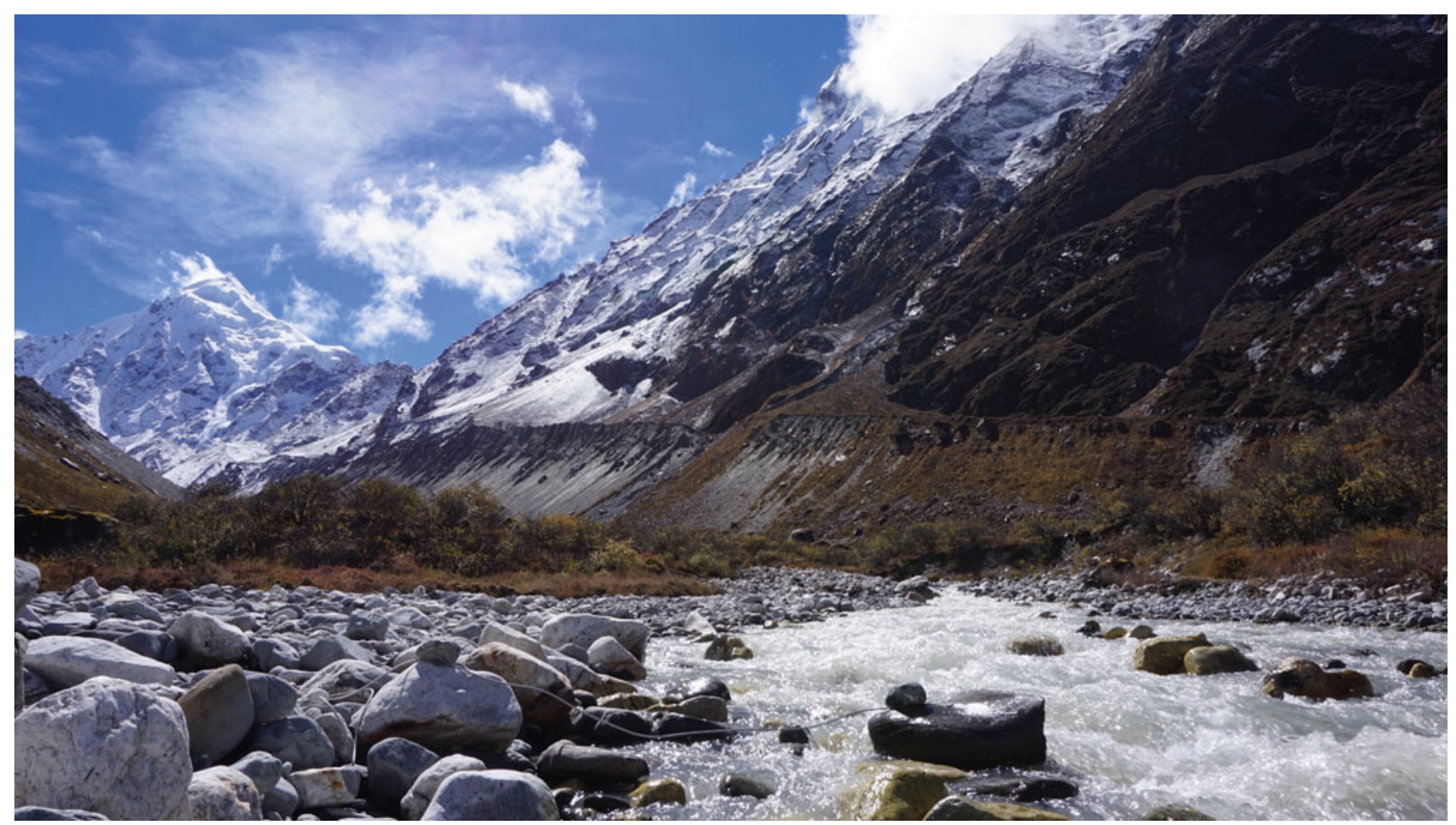

Fig. 7.14 Glacier meltwater from Langshisha Glacier in Langtang valley, Nepal (Photo J. Shea)

mountain areas are also prone to measurement errors. These uncertainties pertain to sensor type (e.g., reading gauge, radar, pressure transducer), river type, and the availability of an accurate rating curve under representative flow conditions (di Baldassarre and Montanari 2009). To our knowledge, no systematic evaluation of discharge rating curves has yet been conducted, which leads to significant uncertainty in runoff observations and any trend analyses.

Increased temperatures have resulted in earlier snowmelt and a shift towards greater flow fractions in winter on the Tibetan Plateau (Ye et al. 2005). Increases in spring temperatures and spring discharge volumes have been observed at lower elevation stations in the Indus (Khattak et al. 2011; Sharif et al. 2013), although some stations show no significant trends. Decreased flows have been observed in snowmelt dominated basins in Nepal (Shrestha and Aryal 2011).

Increased discharge and a correlation with increased summer temperature has been observed in glacierized basins in the Pamir (Chevallier et al. 2014) and on the Tibetan Plateau (Yao et al. 2007; Zhang et al. 2007; Liu et al. 2010). Discharge has decreased in the heavily glacierized Hunza and Shyok catchments of the Karakoram (Fowler and Archer 2006; Khattak et al. 2011; Sharif et al. 2013), where temperatures have also decreased and glacier mass balances have been neutral or slightly positive since the 1970s. The limit and timing of glacier meltwater increases, known as 'peak water' (Baraer et al. 2012), has not been explored in detail in the extended HKH.
Given the multiple factors influencing streamflow, it is not possible to provide conclusive regional evidence of either declining or increasing streamflow trends. Trends change in space and time within a basin. For example, analysis of summer streamflows in the upper Indus basin shows periods of both decline and increase in runoff for the same stations for different decades, and also contradicting trends for the same decade but for different stations (Reggiani et al. 2017). These observations are explained by the conspiring effects of seasonal temperature and precipitation changes and variable dependence of runoff on glacier and snow resources.

\subsubsection{Projections of Cryospheric and Hydrological Change}

In general, overall annual flows are not projected to change significantly with climate change (Lutz et al. 2014), especially in major rivers where monsoon rainfall largely determines total runoff. Shifts in the timing and magnitude of streamflows in mountain rivers, however, will become apparent as climatic and cryospheric changes progress. Basin-scale projections of glacier and hydrological change (e.g., Zhang et al. 2015a, b) also illustrate that variability in projected climate fields can mask changes in glacier contributions to streamflow.

Projected changes in overall runoff are the compound effect of different processes, and few studies have attempted 
to isolate and quantify these effects. Conceptually, an increase in temperature will result in a range of hydrological impacts (Box 7.5):

- More precipitation will fall in the form of rain instead of snow. This will (a) cause the snow line to migrate upwards and result in less seasonal snow storage and a reduction in glacier accumulation, and (b) result in increased rainfall runoff during snowfall seasons. In general, this will reduce the buffering capacity of a catchment and lead to a higher susceptibility to both extreme runoff and prolonged low flows.

- Seasonal snowpack melt rates will increase. Snowmelt will occur earlier in the season and make a larger contribution to total runoff in early spring causing increased probability of floodings,

- Glacier shrinkage will cause glacier contributions to river runoff to increase initially, and then decrease. Glacier melt seasons will be extended and higher temperatures will enhance glacier melt rates. This impact is transient, however, and ice volumes will eventually be sufficiently reduced to limit total meltwater production. More than half the basins in the extended HKH are expected to have reduced glacier melt contributions by 2100 (Shea and Immerzeel 2016).

- The sign and magnitude of changes in evapotranspiration are less clear. The role of evapotranspiration in high-elevation water cycles is unstudied, but evapotranspiration rates are a function of temperature, solar radiation, and wind speed, and are limited primarily by available soil moisture. All things being equal, an increase in temperature will lead to an increased evapotranspiration rate, which may affect river runoff during warmer seasons.

An increase in precipitation will also have various compound hydrological impacts:

- More precipitation implies more rainfall, which will cause more runoff in the rivers, a more capricious runoff pattern, and an increased susceptibility to extreme runoff.

- More rainfall will also cause an increase in soil moisture, which will enhance evapotranspiration rates in relatively dry seasons and thus cause a reduction in streamflow in the shoulder seasons of the monsoon.

- More precipitation implies more snowfall and thus more glacier accumulation. This will contribute to more positive glacier mass balances and a longer period ahead before ice volumes become so small that the contribution to river runoff diminishes.

- More snowfall implies more extensive seasonal snowpacks, which results in a longer snowmelt season with a larger overall amount. This then results in an attenuation of the hydrograph and a reduction in the susceptibility to extremes.

In reality, all these factors may conspire and together they determine the future hydrograph. Given the uncertainties, in particular with regards to future precipitation changes, it is difficult to draw accurate regional conclusions; however, average runoff is likely to be balanced for the coming decades (Immerzeel et al. 2013; Lutz et al. 2014) and dealing with runoff extremes is the largest challenge we face (Lutz et al. 2016).

Although the body of literature regarding future hydrological projections is scarce, the near-, medium-, and long-term projections that are available are presented in the following sections.

\subsubsection{Near-Term Change}

Seasonal snowmelt is the dominant source of streamflow in the pre-monsoon (Apr-Jun) in nearly all catchments across the region, with particular importance in the west (Singh and Bengtsson 2005; Bookhagen and Burbank 2010; Wulf et al. 2016). The most prominent near-term change will likely be observed as a shift in snowmelt timing and magnitude.

The Satluj river basin (western Himalaya), for example, is projected to see increased spring discharge $(+6 \%)$ and decreased summer discharge $(-7 \%)$ in response to $\mathrm{a}+1{ }^{\circ} \mathrm{C}$ temperature increase (Singh and Bengtsson 2005). Projected increases in summer runoff in the Indus are linked to increased snowfall and snowmelt totals, although uncertainty in climate model outputs is large (Ragettli et al. 2013). Other modelling studies have shown shifts in the timing and magnitude of snowmelt runoff across the extended $\mathrm{HKH}$ (Hagg et al. 2006, 2007; Tahir et al. 2011). Decreased snowmelt contributions in lower elevation western basins may reduce water availability during critical irrigation periods (see Chap. 8), but greater low flows in winter and earlier spring snowmelt runoff could potentially benefit hydroelectric power generation (see Chap. 6).

\subsubsection{Medium- and Long-Term Change}

Glacier melt occurs primarily during the monsoon (JunSep), when seasonal snowpacks have retreated to higher elevations and bare ice is exposed to annual maximums of mean daily air temperature and relatively high solar radiation (Box 7.5; Archer 2003). Smaller volumes of ice melt are also produced beneath debris-covered glaciers when energy is transferred from the surface to the debris/ice interface (Benn et al. 2012). Melt conditions for both clean and debris-covered glaciers can occur between March and October, and the hydrological impacts of glacier change will thus be felt primarily during these months. The magnitude 
and significance of hydrological change due to glacier change will depend on climatic setting, and will likely be observed on decadal-to-century timescales (Immerzeel et al. 2012; Lutz et al. 2014; Shea and Immerzeel 2016).

The projected increase in temperatures and decline in glacier areas and volumes (Sect. 7.3) will have compensating effects: glacier melt and runoff will increase initially, but glacier melt contributions will be reduced as glacier area and volumes adjust (Rees and Collins 2006; Immerzeel et al. 2012; Bliss et al. 2014; Lutz et al. 2014; Shea and Immerzeel 2016). A notable exception to this pattern is suggested for the western parts of the extended HKH, where large-scale modelling projects no significant decline in glacier melt until 2100 (Bliss et al. 2014). The loss of glaciers in extended HKH catchments will lead to a reduced buffering capacity, reduced summer melt contributions, and increased streamflow variability (Fountain and Tangborn 1985).

Permafrost degradation, which occurs on decadal-to-century timescales, will lead to an increase in the active layer depth, a greater near-surface water reservoir, and possible increases in drainage (Wang et al. 2000; Niu et al. 2011; Torre Jorgenson et al. 2013).

\subsubsection{Recommendations}

To have confidence in both observations and projections of hydrological change related to cryospheric change, improved and expanded high-elevation monitoring sites are necessary, and should be complemented with remote sensing and modelling efforts. This could include the following:

- Dedicated collaborative research catchments across a range of climatic and elevational zones with hydrological, meteorological, and glaciological observations

- Detailed studies on high elevation snow accumulation, sublimation, and redistribution

- Synoptic and time-series surveys of stable isotopes to estimate streamflow components (Box 7.4), and modelled streamflow contributions.

\section{Box 7.5 Climatological and hydrological change in glacierized watersheds}

As an example of the potential impacts of hydrology on glacierized watersheds, we use the mean daily runoff observed in the Langtang river, Nepal. Above the gauging station, the basin is approximately $25 \%$ glacierized, and detailed hydrological modelling indicates that snowmelt, rainfall, and glacier melt account for 40,36 , and $24 \%$ of annual runoff, respectively (Ragettli et al. 2015). Based on a simple increase in temperature, we impose three separate scenarios on the modelled streamflow contributions (Fig. 7.15):

- More rain, less snow: increased temperatures lead to a $30 \%$ reduction in snowfall. This is added to rainfall derived runoff.

- Increased snow and ice melt: increased temperatures result in a $50 \%$ increase in melt.

- Longer melt season: snowmelt season starts earlier, but total melt contribution remains the same.

As all three impacts will likely be observed simultaneously, in addition to changes in precipitation, the specific attribution of hydrological change in glacierized watersheds is a difficult task. Further, the hydrological response will vary between basins depending on snow accumulation gradients, topography, glacier extent, state, and debris cover.

\subsection{Policy Relevance}

We identify three key areas of policy relevance with regards to the status, trends, and projections for the extended HKH cryosphere.

1. Improved resource allocation for region- and sectorspecific studies of the impacts of cryospheric change (e.g., impacts of glacier and snowpack changes on hydroelectricity, and GLOF hazards in the Himalaya)

In most regions of the extended HKH, glaciers are thinning, losing mass, and retreating, except for western Kunlun and parts of the Karakoram and Pamir where glaciers have been relatively stable over the past decades. In addition, the limited data suggests seasonal snow cover is reducing and permafrost is thawing. Cryospheric change will ultimately influence the seasonal availability of water in the extended HKH river systems. However, our understanding on these issues is limited, and we need to improve our data collection, analyses, and modelling strategies to provide sector- and region-specific details of projected changes. The speed and extent of changes will vary from region to region and may lead to conflicts due to competing demands from different sectors, such as domestic, agriculture, hydropower, and industrial usages. To avoid conflict, and to develop just and equitable water resource distribution policies, targeted studies are needed.

2. High-level international agreements for systematic data collection, data sharing, training, and hazard warnings related to the cryosphere 


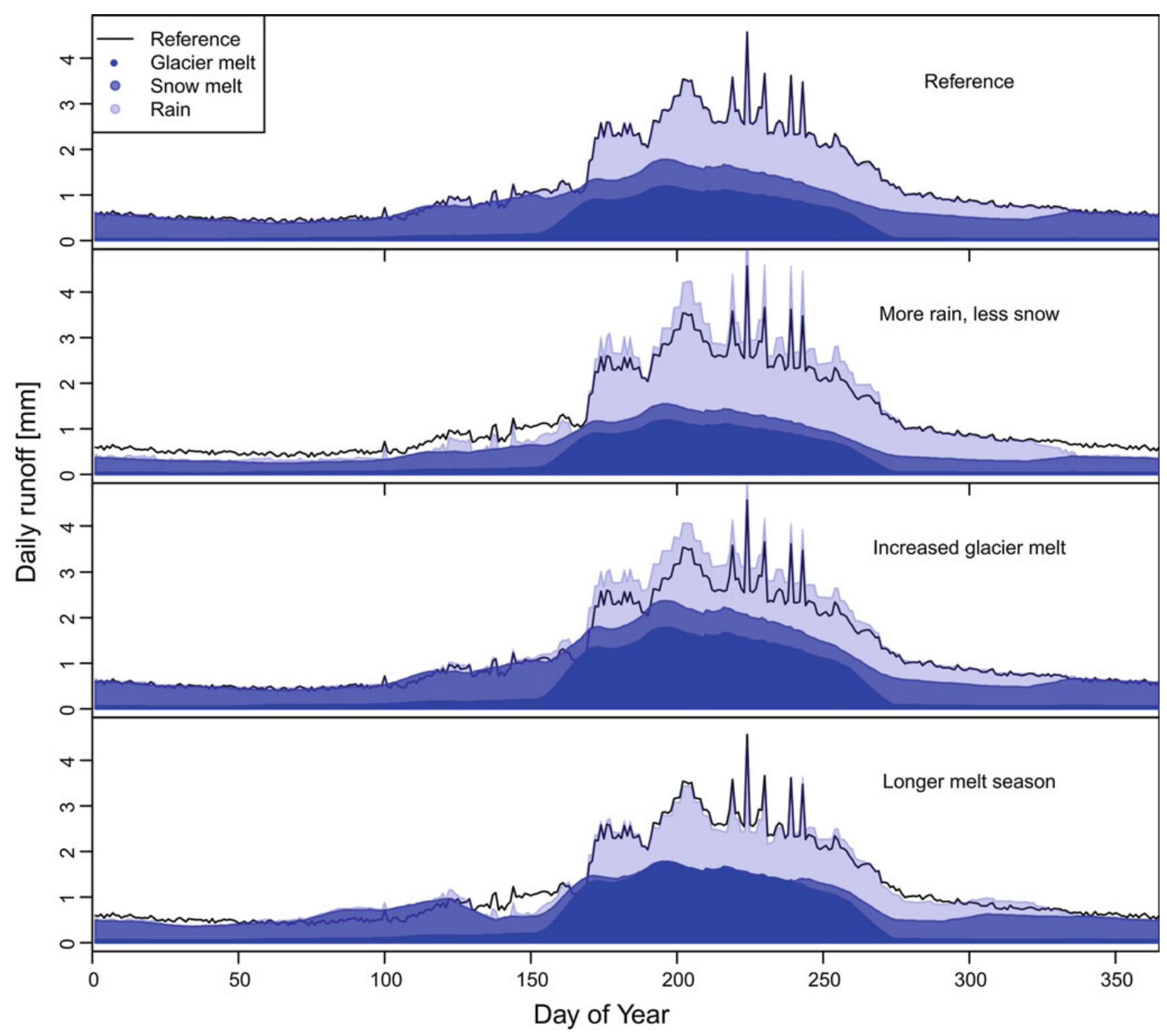

Fig. 7.15 Conceptual changes in streamflow contributions in the Langtang Valley, Nepal

Numerous rivers, such as the Indus, Ganges, and Brahmaputra originate in the high mountains of extended $\mathrm{HKH}$, and the river water is then shared among various countries in the region by agreement, for example the Mahakali Treaty between Nepal and India, the 30-year Ganges (Ganga) water-sharing arrangement between India and Bangladesh, and the Indus water treaty between India and Pakistan. According to the Indus treaty, control over the three 'eastern' rivers (the Beas, Ravi, and Sutlej) was given to India, and the three 'western' rivers (the Indus, Chenab, and Jhelum) to Pakistan. However, in the future, glaciers and snow cover could change differently in the so-called eastern and western basins, leading to substantial change in the availability of water in each basin. This may lead to renegotiation of existing water-sharing treaties. To make informed decisions, we will need a better understanding of the changes in snowand glacier-stored water and its melting processes. This will require proper international agreements for systematic and standardized data collection and sharing on the cryosphere in extended HKH. These agreements should follow guidelines and standards from existing high-level organizations such as the World Glacier Monitoring Service (WGMS, www. wgms.ch), Glacier and Permafrost Hazards in Mountains (GAPHAZ, www.gaphaz.org), and the Global Terrestrial Observing System (GTOS, www.fao.org/gtos/) as part of the Global Climate Observing System (GCOS, public.wmo. int/en/programmes/global-climate-observing-system).

Obtaining access to existing and newly gathered data will be crucial and will provide longer time series for many regions. It will also call for improvement in the existing pool 
of trained scientific personnel and the sharing of best practices in data collection and analysis. It should also be noted, a significant amount of data exists in private hands, such as hydropower companies.

Retreating glaciers can also potentially increase the hazard from glacial lake outburst floods, as new lakes may be formed due to overdeepening of the newly-exposed land and permafrost degradation will increase hazard potential from destabilizing mountain slopes. To minimize damage to human life, property, and the environment, a better transboundary hazard warning system is needed. This will require new international agreements and the development of proper infrastructure to share data and information in real time.

3. Stronger global commitments and actions to reduce GHG emissions due to the recognition that climate change and carbon emissions are global phenomena that significantly affect the extended HKH cryosphere, and hence, also livelihoods in one of the most populated regions (is $+1.5 \mathrm{C}$ enough?)

All projections point towards increased cryospheric changes in the coming decades and centuries in the extended HKH. Decreased snowpacks, accelerated glacier mass loss, and changes in permafrost, rivers, and lakes will occur in response to increased temperatures. These cryospheric changes will directly affect populations both within and downstream of the mountains through changes in hydrology, natural hazard risks, and potential infrastructure losses. Notwithstanding the uncertainties in both the climate projections and the model formulations, high-emission scenarios will result in greater cryospheric impacts than low-emission scenarios. This potential for climate mitigation represents a key policy recommendation: the international community needs to make stronger and more accountable commitments to restrict GHG emissions and meet emission scenarios as given in RCP2.6 or lower.

\begin{abstract}
Acknowledgements The authors acknowledge the contributions of all researchers working in this field, agencies that provide access to field-based and remote sensing datasets, and organizations that work to standardize cryospheric measurements and reporting. We also thank the researchers and colleagues who have graciously provided us with their data and model outputs (Rianne Giesen, Valentina Radic, Ben Marzeion, Daniel Farinotti) and information (Phuntsho Tshering, Inka Koch, Miriam Jackson). We appreciate the specific and general comments of our reviewers and colleagues, and the support of the review editor Koji Fujita. Any remaining errors or omissions are ours.
\end{abstract}

\section{References}

Adhikari, S., \& Huybrechts, P. (2009). Numerical modelling of historical front variations and the 21st-century evolution of glacier AX010, Nepal Himalaya. Annals of Glaciology, 50(52), 27-34.
Aizen, V. B., et al. (1996). Isotopic measurements of precipitation on central Asian glaciers (southeastern Tibet, northern Himalayas, central Tien Shan). Journal of Geophysical Research: Atmospheres, 101(D4), 9185-9196.

Aizen, V. B., et al. (2006). Climatic and atmospheric circulation pattern variability from ice-core isotope/geochemistry records (Altai, Tien Shan and Tibet). Annals of Glaciology, 43, 49-60.

Aizen, V. B., et al. (2009). Stable-isotope and trace element time series from Fedchenko glacier (Pamirs) snow/firn cores. Journal of Glaciology, 55(190), 275-291.

Aizen, V. B., \& Aizen, E. M. (2014). The Central Asia climate and cryosphere/water resources changes. In Materials of the International Conference "Remote- and Ground-based Earth Observations in Central Asia” (pp. 240-245).

Aizen, V. B., Aizen, E. M., \& Melack, J. M. (1995). Climate, snow cover, glaciers, and Runoff in the Tien Shan, Central Asia. Journal of the American Water Resources Association, 31(6), 1113-1129.

Akhtar, M., Ahmad, N., \& Booij, M. J. (2008). The impact of climate change on the water resources of Hindukush-Karakorum-Himalaya region under different glacier coverage scenarios. Journal of Hydrology, 355(1-4), 148-163.

An, W., et al. (2016). Possible recent warming hiatus on the northwestern Tibetan Plateau derived from ice core records. Scientific Reports, 6, 32813.

Andermann, C., Bonnet, S., \& Gloaguen, R. (2011). Evaluation of precipitation data sets along the Himalayan front. Geochemistry, Geophysics, Geosystems 12(7).

Anders, A. M. et al. (2006). Spatial patterns of precipitation and topography in the Himalaya. In S. D. Willett, N. Hovius, M. T. Brandon $\&$ D. Fisher (Eds.), Tectonics, climate, and landscape evolution: Geological society of America special paper 398 (pp. 39-53).

Archer, D. (2003). Contrasting hydrological regimes in the upper Indus Basin. Journal of Hydrology, 274(1), 198-210.

Arendt, A. A. et al. (2015). Randolph glacier inventory-a dataset of global glacier outlines: Version 5.0.

Arendt, A. A. \& Others. (2012). Randolph glacier inventory (RGI), Vers. 1.0: a dataset of global glacier outlines.

Ashraf, A., Naz, R., \& Iqbal, M. B. (2017). Altitudinal dynamics of glacial lakes under changing climate in the Hindu Kush, Karakoram, and Himalaya ranges. Geomorphology, 283, 72-79.

Ashraf, A., Naz, R., \& Roohi, R. (2012). Glacial lake outburst flood hazards in Hindukush, Karakoram and Himalayan Ranges of Pakistan: Implications and risk analysis. Geomatics, Natural Hazards and Risk, 3(2), 113-132.

Azam, M. F., et al. (2016). Meteorological conditions, seasonal and annual mass balances of Chhota Shigri Glacier, western Himalaya, India. Annals of Glaciology, 57(71), 328-338.

Azam, M. F., et al. (2014). Reconstruction of the annual mass balance of Chhota Shigri glacier, Western Himalaya, India, since 1969. Annals of Glaciology, 55, 69-80.

Bahr, D. B., Meier, M. F., \& Peckham, S. D. (1997). The physical basis of glacier volume-area scaling. Journal of Geophysical Research, 102(B9), 20355.

Bajracharya, S. R., \& Shrestha, B. (2011). In S. R. Bajracharya \& B. Shrestha (Eds.), The status of glaciers in the Hindu Kush-Himalayan region. ICIMOD: ICIMOD.

Di Baldassarre, G., \& Montanari, A. (2009). Uncertainty in river discharge observations: A quantitative analysis. Hydrology and Earth System Sciences, 13, 913-921.

Bamber, J. L., \& Rivera, A. (2007). A review of remote sensing methods for glacier mass balance determination. Global and Planetary Change, 59(1-4), 138-148.

Banerjee, A. (2017). Brief communication: Thinning of debris-covered and debris-free glaciers in a warming climate. The Cryosphere, 11 (1), 133-138. 
Bansod, S. D., et al. (2003). Thermal field over Tibetan Plateau and Indian summer monsoon rainfall. International Journal of Climatology, 23(13), 1589-1605.

Bao, W., et al. (2015). Glacier changes during the past 40 years in the West Kunlun Shan. Journal of Mountain Science, 12(2), 344-357.

Baraer, M., et al. (2012). Glacier recession and water resources in Peru's Cordillera Blanca. Journal of Glaciology, 58, 134-150.

Baral, P., et al. (2014). Preliminary results of mass-balance observations of Yala Glacier and analysis of temperature and precipitation gradients in Langtang Valley. Nepal. Annals of Glaciology, 55(66), 9-14.

Barandun, M., et al. (2015). Re-analysis of seasonal mass balance at Abramov glacier 1968-2014. Journal of Glaciology, 61(230), 1103-1117.

Barlow, M., et al. (2005). Modulation of Daily Precipitation over Southwest Asia by the Madden-Julian Oscillation. Monthly Weather Review, 133(12), 3579-3594.

Barnett, T. P., Adam, J. C., \& Lettenmaier, D. P. (2005). Potential impacts of a warming climate on water availability in snow-dominated regions. Nature, 438(7066), 303-309.

Barry, R. G. (1992). Mountain weather and climate (2nd ed.). New York: Routledge.

Barsch, D., \& Jakob, M. (1998). Mass transport by active rockglaciers in the Khumbu Himalaya. Geomorphology, 26(1-3), 215-222.

Baumann, S., Winkler, S., \& Andreassen, L. M. (2009). Mapping glaciers in Jotunheimen, South-Norway, during the "Little Ice Age" maximum. The Cryosphere, 3(2), 231-243.

Beniston, M. (2003). Climatic change in mountain regions: A review of possible impacts. Climatic Change, 59(1), 5-31.

Benn, D. I., et al. (2012). Response of debris-covered glaciers in the Mount Everest region to recent warming, and implications for outburst flood hazards. Earth-Science Reviews, 114(1-2), 156-174.

Benn, D. I., Wiseman, S., \& Hands, K. A. (2001). Growth and drainage of supraglacial lakes on debrismantled Ngozumpa Glacier, Khumbu Himal Nepal. Journal of Glaciology, 47(159), 626-638.

Berthier, E., et al. (2007). Remote sensing estimates of glacier mass balances in the Himachal Pradesh (Western Himalaya, India). Remote Sensing of Environment, 108(3), 327-338.

Beven, K. (2006). A manifesto for the equifinality thesis. Journal of Hydrology, 320(1), 18-36.

Bhambri, R., Bolch, T., Chaujar, R. K., et al. (2011). Glacier changes in the Garhwal Himalaya, India, from 1968 to 2006 based on remote sensing. Journal of Glaciology, 57, 543-556.

Bhambri, R., et al. (2013). Heterogeneity in glacier response in the upper Shyok valley, northeast Karakoram. Cryosphere, 7(5), $1385-1398$.

Bhatt, B. C., \& Nakamura, K. (2006). A climatological-dynamical analysis associated with precipitation around the southern part of the Himalayas. Journal of Geophysical Research: Atmospheres, 111 (D2), D02115.

Bhattacharya, A. et al. (2016). Overall recession and mass budget of Gangotri Glacier, Garhwal Himalayas, from 1965 to 2015 using remote sensing data. Journal of Glaciology, 1-19.

Bliss, A., Hock, R., \& Radić, V. (2014). Global response of glacier runoff to twenty-first century climate change. Journal of Geophysical Research (Earth Surface), 119, 717-730.

Bocchiola, D., et al. (2011). Prediction of future hydrological regimes in poorly gauged high altitude basins: The case study of the upper Indus, Pakistan. Hydrology and Earth System Sciences, 15(7), 2059-2075.

Bolch, T. (2017). Hydrology: Asian glaciers are a reliable water source. Nature, 545(7653), 161-162.

Bolch, T., et al. (2017). Brief communication: Glaciers in the Hunza catchment (Karakoram) have been nearly in balance since the 1970s. The Cryosphere, 11(1), 531-539.
Bolch, T., et al. (2012). The state and fate of Himalayan Glaciers. Science, 336(6079), 310-314.

Bolch, T., Pieczonka, T., \& Benn, D. I. (2011a). Multi-decadal mass loss of glaciers in the Everest area (Nepal Himalaya) derived from stereo imagery. Cryosphere, 5(2), 349-358.

Bolch, T., et al. (2011b). Identification of potentially dangerous glacial lakes in the northern Tien Shan. Natural Hazards, 59(3), 16911714.

Bolch, T., Menounos, B., \& Wheate, R. (2010a). Landsat-based inventory of glaciers in western Canada, 1985-2005. Remote Sensing of Environment, 114(1), 127-137.

Bolch, T., et al. (2010b). A glacier inventory for the western Nyainqentanglha range and the Nam Co Basin, Tibet, and glacier changes 1976-2009. Cryosphere, 4(3), 419-433.

Bolch, T., et al. (2008). Planimetric and volumetric glacier changes in the Khumbu Himal, Nepal, since 1962 using Corona, Landsat TM and ASTER data. Journal of Glaciology, 54(187), 592-600.

Bommer, C., Phillips, M., \& Arenson, L. U. (2010). Practical recommendations for planning, constructing and maintaining infrastructure in mountain permafrost. Permafrost and Periglacial Processes, 21(1), 97-104.

Bookhagen, B., \& Burbank, D. W. (2006). Topography, relief, and TRMM-derived rainfall variations along the Himalaya. Geophysical Research Letters, 33(8), L08405.

Bookhagen, B., \& Burbank, D. W. (2010). Toward a complete Himalayan hydrological budget: Spatiotemporal distribution of snowmelt and rainfall and their impact on river discharge. Journal of Geophysical Research: Earth Surface, 115(3), 1-25.

Bräuning, A. (2006). Tree-ring evidence of "Little Ice Age" glacier advances in southern Tibet. The Holocene, 16(3), 369-380.

Brun, F., et al. (2017). A spatially resolved estimate of High Mountain Asia glacier mass balances from 2000 to 2016. Nature Geoscience, 10(9), 668-673.

Brun, F., et al. (2015). Seasonal changes in surface albedo of Himalayan glaciers from MODIS data and links with the annual mass balance. Cryosphere, 9(1), 341-355.

Buri, P., et al. (2016). A grid-based model of backwasting of supraglacial ice cliffs on debris-covered glaciers. Annals of Glaciology, 57(71), 199-211.

Burn, C. R., \& Nelson, F. E. (2006). Comment on "A projection of severe near-surface permafrost degradation during the 21st century" by David M. Lawrence and Andrew G. Slater. Geophysical Research Letters, 33(21), L21503.

Chand, P., \& Sharma, M. C. (2015). Glacier changes in the Ravi basin, North-Western Himalaya (India) during the last four decades (1971-2010/13). Global and Planetary Change, 135, 133-147.

Chang, A. T. C., Foster, J. L., \& Hall, D. K. (1987). Nimbus-7 SMMR derived global snow cover parameters. Annals of Glaciology, 9, 39-44.

Chaturvedi, R. K., et al. (2014). Glacial mass balance changes in the Karakoram and Himalaya based on CMIP5 multi-model climate projections. Climatic Change, 123(2), 315-328.

Che, T., Li, X., \& Dai, L. (2011). Monitoring freeze-up and break-up dates of Northern Hemisphere big lakes using passive microwave remote sensing data. In 2011 IEEE International Geoscience and Remote Sensing Symposium (pp. 3191-3193), IEEE.

Che, T., Li, X., \& Jin, R. (2009). Monitoring the frozen duration of Qinghai Lake using satellite passive microwave remote sensing low frequency data. Chinese Science Bulletin, 54(13), 2294-2299.

Chen, F., Zhang, M., Tian, B., \& Li, Z. (2017). Extraction of glacial Lake outlines in Tibet plateau using landsat 8 imagery and google earth engine. IEEE Journal of Selected Topics in Applied Earth Observations and Remote Sensing, 10(9), 4002-4009.

Cheng, G., \& Wang, S. (1983). Distributive regularities of high ice-content permafrost along Qinghai-Xizang Highway. In 
Proceedings of the 4th International Conference on Permafrost (pp. 142-146).

Chevallier, P., et al. (2014). River flow regime and snow cover of the Pamir Alay (Central Asia) in a changing climate. Hydrological Sciences Journal, 59(8), 1491-1506.

Cogley, J. G. (2009). Geodetic and direct mass balance measurements: Comparison and joint analysis. Annals of Glaciology, 50(50), 96100.

Cogley, J. G. (2011). Present and future states of Himalaya and Karakoram glaciers. Annals of Glaciology, 52(59), 69-73.

Collier, E., \& Immerzeel, W. W. (2015). High-resolution modeling of atmospheric dynamics in the Nepalese Himalaya. Journal of Geophysical Research: Atmospheres, 120(19), 9882-9896.

Copland, L., et al. (2011). Expanded and recently increased glacier surging in the Karakoram. Arctic, Antarctic, and Alpine Research, 43(4), 503-516.

Dahri, Z. H., et al. (2016). An appraisal of precipitation distribution in the high-altitude catchments of the Indus basin. Science of the Total Environment, 548-549, 289-306.

Dahri, Z.H. et al., 2011. satellite-based snowcover distribution and associated snowmelt runoff modeling in Swat River Basin of Pakistan. In Proceedings of Pakistan Academy of Sciences, Islamabad, Pakistan (pp. 19-32).

Deline, S., et al. (2015). Ice loss and slope stability in high-mountain regions. In W. Haeberli, C. Whiteman, \& J. F. Shroder (Eds.), Snow and Ice-Related hazards, risks, and disasters (pp. 521-561). Saint Louis: Elsevier Science.

Delisle, G., 2007. Near-surface permafrost degradation: How severe during the 21st century? Geophysical Research Letters, 34(9).

Dibike, Y. et al. (2011). Response of Northern Hemisphere lake-ice cover and lake-water thermal structure patterns to a changing climate. Hydrological Processes, 25(19), n/a-n/a.

Dietz, A. J., Kuenzer, C., \& Conrad, C. (2013). Snow-cover variability in central Asia between 2000 and 2011 derived from improved MODIS daily snow-cover products. International Journal of Remote Sensing, 34(11), 3879-3902.

Diffenbaugh, N. S., Scherer, M., \& Ashfaq, M. (2013). Response of snow-dependent hydrologic extremes to continued global warming. Nature climate change, 3(4), 379-384.

Dolgoushin, L. D., \& Osipova, G. B. (1975). Glacier surges and the problem of their forecasting. In Snow and Ice-Symposium-Neiges et Glaces (Proceedings of the Moscow Symposium, August 1971; Actes du Colloque de Moscou, août 1971), IAHS-AISH (pp. 292-304).

Doré, G., Niu, F., \& Brooks, H. (2016). Adaptation methods for transportation infrastructure built on degrading permafrost. Permafrost and Periglacial Processes, 27(4), 352-364.

Duan, K., Xu, B., \& Wu, G. (2015a). Snow accumulation variability at altitude of 7010 m a.s.l. in Muztag Ata Mountain in Pamir Plateau during 1958-2002. Journal of Hydrology, 531(9), 912-918.

Duan, K., Xu, B., \& Wu, G. (2015b). Snow accumulation variability at altitude of $7010 \mathrm{~m}$ a.s.l. in Muztag Ata Mountain in Pamir Plateau during 1958-2002. Journal of Hydrology, 531, 912-918.

Dumont, M., et al. (2012). Linking glacier annual mass balance and glacier albedo retrieved from MODIS data. Cryosphere, 6(6), $1527-1539$.

Dyurgerov, M. B., \& Meier, M. F. (2005). Glaciers and the changing Earth system: A 2004 snapshot (Vol. 58). Boulder, CO: Institute of Arctic and Alpine Research, University of Colorado.

Farhan, S. Bin, et al. (2014). Hydrological regimes under the conjunction of westerly and monsoon climates: A case investigation in the Astore Basin, Northwestern Himalaya. Climate Dynamics, 44 (11-12), 3015-3032.
Farinotti, D., et al. (2017). How accurate are estimates of glacier ice thickness? Results from ITMIX, the Ice thickness models intercomparison eXperiment. The Cryosphere, 11(2), 949-970.

Fiddes, J., Endrizzi, S., \& Gruber, S. (2015). Large-area land surface simulations in heterogeneous terrain driven by global data sets: application to mountain permafrost. The Cryosphere, 9(1), 411-426.

Finsterwalder, R. (1954). Photogrammetry and glacier research with special reference to glacier retreat in the eastern Alps. Journal of Glaciology, 2, 306-315.

Førland, E. J., Allerup, P., Dahlström, B., Elomaa, E., Jónsson, T., Madsen, H., Perälä, J., Rissanen, P., Vedin, H., \& Vejen, F. (1996). Manual for operational correction of Nordic precipitation data. DNMI report, 24, 96.

Forsythe, N., et al. (2014). Application of a stochastic weather generator to assess climate change impacts in a semi-arid climate: The Upper Indus Basin. Journal of Hydrology, 517, 1019-1034.

Fort, M. (2003). Are high altitude, lava stream-like, debris mixtures all rock glaciers? Zeitschrift für Geomorphologie, 47, 11-29.

Fort, M. (2015). Natural hazards versus climate change and their potential impacts in the dry, northern Himalayas: Focus on the upper Kali Gandaki (Mustang District, Nepal). Environmental Earth Sciences, 73(2), 801-814.

Fort, M., \& van Vliet-Lanoe, B. (2007). Permafrost and periglacial environment of Western Tibet. Landform Analysis, 5, 25-29.

Foster, J. L., et al. (2011). A blended global snow product using visible, passive microwave and scatterometer satellite data. International Journal of Remote Sensing, 32(5), 1371-1395.

Fountain, A. G., et al. (2009). The "benchmark glacier" concept-Does it work? Lessons from the North Cascade Range, USA. Annals of Glaciology, 50(50), 163-168.

Fountain, A. G., \& Tangborn, W. V. (1985). The effect of glaciers on streamflow. Water Resources Research, 21(4), 579-586.

Fowler, H. J., \& Archer, D. (2006). Conflicting signals of climatic change in the Upper Indus Basin. Journal of Climate, 19(17), 4276-4293.

Frei, A., et al. (2012). A review of global satellite-derived snow products. Advances in Space Research, 50(8), 1007-1029.

La Frenierre, J., \& Mark, B. G. (2014). A review of methods for estimating the contribution of glacial meltwater to total watershed discharge. Progress in Physical Geography.

Frey, H., et al. (2010). A multi-level strategy for anticipating future glacier lake formation and associated hazard potentials. Natural Hazards and Earth System Science, 10(2), 339-352.

Frey, H., et al. (2014). Estimating the volume of glaciers in the Himalayan\&ndash; Karakoram region using different methods. The Cryosphere, 8(6), 2313-2333.

Frey, H., Paul, F., \& Strozzi, T. (2012). Compilation of a glacier inventory for the western Himalayas from satellite data: Methods, challenges, and results. Remote Sensing of Environment, 124, 832-843.

Fujita, K., Ageta, Y., Pu, J., \& Yao, T. (2000). Mass balance of Xiao Dongkemadi Glacier on central Tibetan Plateau from 1989 to 1995. Annals of Glaciology, 31, 159-163.

Fujita, K., et al. (2008). Performance of ASTER and SRTM DEMs, and their potential for assessing glacial lakes in the Lunana region, Bhutan Himalaya. Journal of Glaciology, 54(185), 220-228.

Fujita, K., et al. (2013). Potential flood volume of Himalayan glacial lakes. Natural Hazards and Earth System Science, 13(7), $1827-1839$.

Fujita, K., et al. (2009). Recent changes in Imja Glacial Lake and its damming moraine in the Nepal Himalaya revealed by in situ surveys and multi-temporal ASTER imagery. Environmental Research Letters, 4(4), 45205. 
Fujita, K., \& Nuimura, T. (2011). Spatially heterogeneous wastage of Himalayan glaciers. Proceedings of the National Academy of Sciences, 108(34), 14011-14014.

Gao, J., et al. (2012). Spatiotemporal distribution of snow in eastern Tibet and the response to climate change. Remote Sensing of Environment, 121, 1-9.

Gardelle, J., et al. (2013). Region-wide glacier mass balances over the Pamir-Karakoram-Himalaya during 1999-2011. The Cryosphere, 7 (4), 1263-1286.

Gardelle, J., Arnaud, Y., \& Berthier, E. (2011). Contrasted evolution of glacial lakes along the Hindu Kush Himalaya mountain range between 1990 and 2009. Global and Planetary Change, 75(1-2), 47-55.

Gardner, A. S., et al. (2013). A reconciled estimate of glacier contributions to sea level rise: 2003 to 2009. Science, 340(6134), $852-857$.

Gärtner-Roer, I., et al. (2014). A database of worldwide glacier thickness observations. Global and Planetary Change, 122, 330-344.

Garzione, C. N. et al. (2000). Predicting paleoelevation of Tibet and the Himalaya from $\delta 18 \mathrm{O}$ vs. altitude gradients in meteoric water across the Nepal Himalaya. Earth and Planetary Science Letters, 183(1), pp. 215-229.

Germann, U., et al. (2006). Radar precipitation measurement in a mountainous region. Quarterly Journal of the Royal Meteorological Society, 132(618), 1669-1692.

Ghatak, D., Eric, S., \& James, M. (2014). Role of snow-albedo feedback in higher elevation warming over the Himalayas, Tibetan Plateau and Central Asia. Environmental Research Letters, 9(11), 114008 .

Giesen, R. H., \& Oerlemans, J. (2013). Climate-model induced differences in the 21 st century global and regional glacier contributions to sea-level rise. Climate Dynamics, 41(11-12), 3283-3300.

Gorbunov, A. (1990). Permafrost in the arid mountains of middle asia - the eastern Pamirs, USSR. Permafrost and Periglacial Processes, 1, 309-312.

Gorbunov, A. P. (1978). Permafrost investigations in high-mountain regions. Arctic and Alpine Research, 10(2), 283-294.

Gorbunov, A. P., \& Titkov, S. N. (1989). Kamennye Gletchery Gor Srejnej Azii (Rockglaciers of Central Asian Mountains). Irkutsk: Akademia Nauk SSSR.

Groisman, P. Y., et al. (1994). Changes of snow cover, temperature, and Radiative heat balance over the Northern Hemisphere. Journal of Climate, 7(11), 1633-1656.

Gruber, S. (2012). Derivation and analysis of a high-resolution estimate of global permafrost zonation. The Cryosphere, 6(1), 221-233.

Gruber, S., Fleiner, R., Guegan, E., Panday, P., Schmid, M.-O., et al. (2017). Review article: Inferring permafrost and permafrost thaw in the mountains of the Hindu Kush Himalaya region. The Cryosphere, 11(1), 81-99.

Guo, D., Wang, H., \& Li, D. (2012). A projection of permafrost degradation on the Tibetan Plateau during the 21 st century. Journal of Geophysical Research: Atmospheres, 117(D5), n/a-n/a.

Guo, W., et al. (2013). The 2008/09 surge of central Yulinchuan glacier, northern Tibetan Plateau, as monitored by remote sensing. Annals of Glaciology, 54(63), 299-310.

Guo, W., et al. (2015). The second Chinese glacier inventory: Data, methods and results. Journal of Glaciology, 61(226), 357-372.

Gurung, D. R., et al. (2011). Snow-cover mapping and monitoring in the HinduKush-Himalayas. Kathmandu, Nepal: ICIMOD.

Gurung, H. (1999). Mountains of Asia. Kathmandu: ICIMOD.

Haeberli, W., et al. (2007). Integrated monitoring of mountain glaciers as key indicators of global climate change: The European Alps. Annals of Glaciology, 46, 150-160.
Haeberli, W., et al. (2010). Mountain permafrost: development and challenges of a young research field. Journal of Glaciology, 56 (200), 1043-1058.

Haeberli, W., Schaub, Y., \& Huggel, C. (2016). Increasing risks related to landslides from degrading permafrost into new lakes in de-glaciating mountain ranges. Geomorphology.

Haeberli, W., \& Hoelzle, M. (1995). Application of inventory data for estimating characteristics of and regional climate-change effects on mountain glaciers: A pilot study with the European Alps. Annals of Glaciology, 206-212.

Hagg, W., et al. (2007). Modelling of hydrological response to climate change in glacierized Central Asian catchments. Journal of Hydrology, 332(1-2), 40-53.

Hagg, W. et al. (2006). Runoff modelling in glacierized Central Asian catchments for present-day and future climate. Hydrology Research, $37(2)$.

Hall, D. K. et al. (2006). Estimation of snow extent and snow properties. In Encyclopedia of hydrological sciences. Wiley.

Haritashya, U. K., et al. (2009). Space-based assessment of glacier fluctuations in the Wakhan Pamir, Afghanistan. Climatic Change, 94(1-2), 5-18.

Harper, J. T., \& Humphrey, N. F. (2003). High altitude Himalayan climate inferred from glacial ice flux. Geophysical Research Letters, 30(14).

Hasson, S., et al. (2014). Early 21 st century snow cover state over the western river basins of the Indus River system. Hydrology and Earth System Sciences, 18(10), 4077-4100.

Herreid, S., et al. (2015). Satellite observations show no net change in the percentage of supraglacial debris-covered area in northern Pakistan from 1977 to 2014. Journal of Glaciology, 61(227), 524-536.

Hewitt, K. (2011). Glacier change, concentration, and elevation effects in the Karakoram Himalaya, Upper Indus Basin. Mountain Research and Development, 31(3), 188-200.

Hewitt, K. (2014). Glaciers of the Karakoram Himalaya. Dordrecht, The Netherlands: Springer.

Hewitt, K., et al. (1988). Hydrological investigations at Biafo Glacier, Karakorum Range, Himalaya; an important source of water for the Indus River. Annals of Glaciology, 13, 103-108.

Hewitt, K. (2005). The Karakoram anomaly? Glacier expansion and the "elevation effect". Karakoram Himalaya. Mountain Research and Development, 25(4), 332-340.

Hewitt, K. (2007). Tributary glacier surges: An exceptional concentration at Panmah Glacier, Karakoram Himalaya. Journal of Glaciology, 53(181), 181-188.

Hewitt, K., \& Liu, J. (2010). Ice-Dammed lakes and outburst floods, Karakoram Himalaya: Historical perspectives on emerging threats. Physical Geography, 31(6), 528-551.

Hinzman, L. D., et al. (2005). Evidence and implications of recent climate change in northern Alaska and other Arctic regions. Climatic Change, 72(3), 251-298.

Hock, R., \& Jensen, H. (1999). Application of kriging interpolation for glacier mass balance computations. Geografiska Annaler, 81A, 611-619.

Holzer, N., et al. (2015). Four decades of glacier variations at Muztagh Ata (eastern Pamir): A multi-sensor study including Hexagon KH-9 and Pléiades data. Cryosphere, 9(6), 2071-2088.

Holzer, N., et al. (2016). Glacier variations in the Trans Alai massif and the Lake Karakul catchment (northeastern Pamir) measured from space. Climate change, glacier response, and vegetation dynamics in the Himalaya (pp. 139-153). Cham: Springer International Publishing.

Hou, S. G., et al. (2002). Recent change of the ice core accumulation rates on the Qinghai-Tibetan Plateau. Chinese Science Bulletin, 47 (20), 1746-1749. 
Huggel, C., et al. (2013). Detecting potential climate signals in large slope failures in cold mountain regions. In C. Margottini (Ed.), Landslide science and practice (Vol. 7, pp. 361-367). Berlin, Heidelberg: Springer.

Huss, M., \& Farinotti, D. (2012). Distributed ice thickness and volume of all glaciers around the globe. Journal of Geophysical Research (Earth Surface), 117, 4010.

Huss, M., \& Hock, R., 2015. A new model for global glacier change and sea-level rise. Frontiers in Earth Science, 3(54).

ICIMOD. (2011). Glacial lakes and glacial lake outburst floods in Nepal. Kathmandu: ICIMOD.

Immerzeel, W. W., et al. (2015). Reconciling high-altitude precipitation in the upper Indus basin with glacier mass balances and runoff. Hydrology and Earth System Sciences, 19(11), 4673-4687.

Immerzeel, W. W., Kraaijenbrink, P. D. A., Shea, J. M., Shrestha, A. B., Pellicciotti, F., Bierkens, M. F. P., et al. (2014). High-resolution monitoring of Himalayan glacier dynamics using unmanned aerial vehicles. Remote Sensing of Environment, 150, 93-103.

Immerzeel, W. W., Pellicciotti, F., \& Bierkens, M. F. P. (2013). Rising river flows throughout the twenty-first century in two Himalayan glacierized watersheds. Nature Geoscience, 6(9), 742-745.

Immerzeel, W. W., et al. (2012). Hydrological response to climate change in a glacierized catchment in the Himalayas. Climatic Change, 110(3-4), 721-736.

Immerzeel, W. W., van Beek, L. P. H., \& Bierkens, M. F. P. (2010). Climate change will affect the Asian water towers. Science, 328, 1382-1385.

Immerzeel, W. W., Droogers, P., \& Bierkens, M. F. P. (2009). Large-scale monitoring of snow cover and runoff simulation in Himalayan river basins using remote sensing. Remote Sensing of Environment, 113, 40-49.

International Hydrological Decade. (1970). Combined heat, ice and water balances at selected glacier basins. UNESCO Technical Papers in Hydrology, 5, 20.

IPCC, 2013. AR5-Summary for Policymakers.

Ives, J. D., Shrestha, R. B., \& Mool, P. (2010). Formation of glacial lakes in the Hindu Kush-Himalayas and GLOF risk assessment. Kathmandu: ICIMOD.

Iwata, S. (1976). Late Pleistocene and holocene region, moraines Khumbu in the Himal * Sagarmatha (Everest). Journal of the Japanese Society of Snow and Ice, 38(Special), 109-114.

Iwata, S., et al. (2003). Rock glaciers and the lower limit of mountain permafrost in the Bhutan Himalayas. Zeitschrift für Geomorphologie N. F. Supplementalband, 130, 129-143.

Jacob, T., et al. (2012). Recent contributions of glaciers and ice caps to sea level rise. Nature, 482(7386), 514-518.

Jacobi, H. W., et al. (2015). Black carbon in snow in the upper Himalayan Khumbu Valley, Nepal: Observations and modeling of the impact on snow albedo, melting, and radiative forcing. Cryosphere, 9(4), 1685-1699.

Jakob, M. (1992). Active rock glaciers and the lower limit of discontinuous alpine permafrost, Khumbu Himalaya, Nepal. Permafrost and Periglacial Processes, 3, 253-256.

Jeelani, G. et al. (2016). Estimation of snow and glacier melt contribution to Liddar stream in a mountainous catchment, western Himalaya: An isotopic approach. Isotopes in Environmental and Health Studies, 1-18.

Jiang, S., et al. (2013). Response of glacier variation to climate change in the Bukatage Ice Cap from 1973 to 2010. Journal of Arid Land Resources \& Environment, 27(3), 47-52.

Jiang, Y., et al. (2008). Long-Term changes in ice phenology of the yellow river in the past decades. Journal of Climate, 21(18), 4879-4886.
Kääb, A., et al. (2015). Brief Communication: Contending estimates of 2003-2008 glacier mass balance over the Pamir-KarakoramHimalaya. The Cryosphere, 9, 557-564.

Kääb, A., et al. (2012). Contrasting patterns of early twentyfirst-century glacier mass change in the Himalayas. Nature, 488 (7412), 495-498.

Kamp, U., Byrne, M., \& Bolch, T. (2011). Glacier fluctuations between 1975 and 2008 in the Greater Himalaya Range of Zanskar, southern Ladakh. Journal of Mountain Science, 8(3), 374-389.

Kang, S., et al. (2002). Stable-isotopic composition of precipitation over the northern slope of the central Himalaya. Journal of Glaciology, 48(163), 519-526.

Kang, S., et al. (2010). Review of climate and cryospheric change in the Tibetan Plateau. Environmental Research Letters, 5(1), 15101.

Kang, S., et al. (2015). Dramatic loss of glacier accumulation area on the Tibetan Plateau revealed by ice core tritium and mercury records. The Cryosphere, 9(3), 1213-1222.

Kapnick, S. B., et al. (2014). Snowfall less sensitive to warming in Karakoram than in Himalayas due to a unique seasonal cycle. Nature Geosci, 7(11), 834-840.

Karim, A., \& Veizer, J. (2002). Water balance of the Indus River Basin and moisture source in the Karakoram and western Himalayas: Implications from hydrogen and oxygen isotopes in river water. Journal of Geophysical Research, 107(D18), 4362.

Kaser, G., Fountain, A. G., \& Jansson, P. (2003). A manual for monitoring the mass balance of mountain glaciers, Paris: IHP-VI Technical Documents in Hydrology, No. 59, UNESCO.

Kaser, G., Grosshauser, M., \& Marzeion, B. (2010). Contribution potential of glaciers to water availability in different climate regimes. Proceedings of the National Academy of Science, 107, 20223-20227.

Kaspari, S., et al. (2008). Snow accumulation rate on Qomolangma (Mount Everest), Himalaya: Synchroneity with sites across the Tibetan Plateau on 50-100 year timescales. Journal of Glaciology, 54(185), 343-352.

Ke, C.-Q., Tao, A.-Q., \& Jin, X. (2013). Variability in the ice phenology of Nam Co Lake in central Tibet from scanning multichannel microwave radiometer and special sensor microwave/imager: 1978 to 2013. Journal of Applied Remote Sensing, 7(1), 73477.

Kehrwald, N. M., et al. (2008). Mass loss on himalayan glacier endangers water resources. Geophysical Research Letters, 35(22), 1-6.

Khan, A., Naz, B. S., \& Bowling, L. C. (2015). Separating snow, clean and debris covered ice in the Upper Indus Basin, Hindukush-Karakoram-Himalayas, using Landsat images between 1998 and 2002. Journal of Hydrology, 521, 46-64.

Khattak, M. S., Babel, M. S., \& Sharif, M. (2011). Hydro-meteorological trends in the upper Indus River basin in Pakistan. Climate Research, 46(2), 103-119.

Khromova, T. E., et al. (2006). Changes in glacier extent in the eastern Pamir, Central Asia, determined from historical data and ASTER imagery. Remote Sensing of Environment, 102(1), 24-32.

Klimeš, L., \& Doležal, J. (2010). An experimental assessment of the upper elevational limit of flowering plants in the western Himalayas. Ecography, 33, 590-596.

König, M., Winther, J.-G., \& Isaksson, E. (2001). Measuring snow and glacier ice properties from satellite. Reviews of Geophysics, 39(1), 1-27.

Koskinen, J. T., Pulliainen, J. T., \& Hallikainen, M. T. (1997). The use of ERS-1 SAR data in snow melt monitoring. IEEE Transactions on Geoscience and Remote Sensing, 35(3), 601-610.

Kotlyakov, V. M., Osipova, G. B., \& Tsvetkov, D. G. (2008). Monitoring surging glaciers of the Pamirs, central Asia, from space. In Annals of Glaciology, 125-134. 
Kraaijenbrink, P. D. A. et al. (2017). Impact of a global temperature rise of $1.5^{\circ}$ Celsius on Asia's glaciers. Nature, 549(7671), 257-260.

Krautblatter, M., Funk, D., \& Günzel, F. K. (2013). Why permafrost rocks become unstable: a rock-ice-mechanical model in time and space. Earth Surface Processes and Landforms, 38(8), 876-887.

Kronenberg, M. et al. (2016). Mass-balance reconstruction for Glacier No. 354, Tien Shan, from 2003 to 2014. Annals of Glaciology, 57 (71), 92-102.

Kropáček, J., et al. (2013). Analysis of ice phenology of lakes on the Tibetan Plateau from MODIS data. The Cryosphere, 7(1), 287-301.

Kulkarni, A., et al. (2016). Projected climate change in the Hindu KushHimalayan region by using the high-resolution regional climate model PRECIS. Mountain Research and Development, 33(2), 142-151.

Lambrecht, A., et al. (2014). The evolution of Fedchenko glacier in the Pamir, Tajikistan, during the past eight decades. Journal of Glaciology, 60(220), 233-244.

Leclercq, P. W., \& Oerlemans, J. (2012). Global and hemispheric temperature reconstruction from glacier length fluctuations. Climate Dynamics, 38(5-6), 1065-1079.

Leysinger Vieli, G. J.-M. C., \& Gudmundsson, G. H. (2004). On estimating length fluctuations of glaciers caused by changes in climatic forcing. Journal of Geophysical Research, 109(F01007), F01007.

Li, C. et al. (2017). Spatiotemporal variation of snow cover over the Tibetan Plateau based on MODIS snow product, 2001-2014. International Journal of Climatology.

$\mathrm{Li}$, H., et al. (2016). Water resources under climate change in Himalayan Basins. Water Resources Management, 30(2), 843-859.

Li, M., et al. (2009). Snow distribution over the Namco lake area of the Tibetan Plateau. Hydrology and Earth System Sciences, 13(11), 2023-2030.

Li, X., et al. (2008). Cryospheric change in China. Global and Planetary Change, 62(3-4), 210-218.

Li, Z., et al. (2011). Climate and glacier change in southwestern China during the past several decades. Environmental Research Letters, 6 (4), 45404.

Lin, H., et al. (2017). A decreasing glacier mass balance gradient from the edge of the Upper Tarim Basin to the Karakoram during 20002014. Scientific reports, 7(1), 6712.

Linsbauer, A., et al. (2016). Modelling glacier-bed overdeepenings and possible future lakes for the glaciers in the Himalaya-Karakoram region. Annals of Glaciology, 57(71), 119-130.

Linsbauer, A., Paul, F., \& Haeberli, W. (2012). Modeling glacier thickness distribution and bed topography over entire mountain ranges with GlabTop: Application of a fast and robust approach. Journal of Geophysical Research (Earth Surface), 117, 3007.

Liu, B. et al. (2013). Wet precipitation chemistry at a high-altitude site (3,326 m a.s.1.) in the southeastern Tibetan Plateau. Environmental Science and Pollution Research, 20(7), 5013-5027.

Liu, C. H., et al. (2000). Glacier resources and their distributive characteristics in China-A review on Chinese Glacier Inventory. Journal of Glaciology and Geocryology, 22(2), 106-112.

Liu, Q., et al. (2016). Recent glacier and glacial lake changes and their interactions in the Bugyai Kangri, southeast Tibet. Annals of Glaciology, 57(71), 61-69.

Liu, Q., et al. (2010). Recent shrinkage and hydrological response of Hailuogou glacier, a monsoon temperate glacier on the east slope of Mount Gongga, China. Journal of Glaciology, 56(196), 215-224.

Liu, S., et al. (2003). Glacier changes since the Little Ice Age Maximum in the western Qilian Mountains, northwest China. Journal of Glaciology, 49(164), 117-124.

Liu, S. et al. (2006). Glacier retreat as a result of climate warming and increased precipitation in the Tarim river basin, northwest China. Annals of Glaciology, 91-96).
Liu, S. Y., et al. (2002). Glacier variation from maximum of the little ice age in the western Qilian Mountains, Northwest China. Journal of Glaciology and Geocryology, 24(3), 227-233. (in Chinese).

Loibl, D. M., \& Lehmkuhl, F. (2014). Glaciers and equilibrium line altitudes of the eastern Nyainqêntanglha Range, SE Tibet. Journal of Maps, (June), 1-14.

Lüthi, Z. L., et al. (2015). Atmospheric brown clouds reach the Tibetan Plateau by crossing the Himalayas. Atmospheric Chemistry and Physics, 15(11), 6007-6021.

Lutz, A. F., et al. (2014). Consistent increase in High Asia's runoff due to increasing glacier melt and precipitation. Nature Climate Change, 4(7), 587-592.

Lutz, A. F. et al. (2016). Climate change impacts on the upper indus hydrology: Sources, shifts and extremes. PLoS One (Vol. 11(11)).

Ma, L., et al. (2010). Sensitivity of the number of snow cover days to surface air temperature over the Qinghai-Tibetan Plateau. Advances in Climate Change Research, 1(2), 76-83.

Ma, L. (2008). In The Temporal and Spatial Characteristics of Snow Depth over the Qinghai-Tibetan Plateau in the Recent 50 Years and its Relationship with Factors of Atmospheric Circulation (in Chinese). Chinese Academy of Meteorological Sciences/Graduate University of Chinese Academy of Sciences.

Ma, Y., et al. (2008). Roof of the World: Tibetan observation and research platform. Bulletin of the American Meteorological Society, 89(10), 1487-1492.

Maanya, U. S., et al. (2016). Identification of potential glacial lake sites and mapping maximum extent of existing glacier lakes in Drang Drung and Samudra Tapu glaciers, Indian Himalaya. Current Science, 111(3), 553-560.

Magnuson, J. J. et al. (2000). Historical trends in Lake and River Ice cover in the Northern Hemisphere. Science, 289(5485).

Malik, N., Bookhagen, B., \& Mucha, P. J. (2016). Spatiotemporal patterns and trends of Indian monsoonal rainfall extremes. Geophysical Research Letters, 43(4), 1710-1717.

Marchenko, S. S., Gorbunov, A. P., \& Romanovsky, V. E. (2007). Permafrost warming in the Tien Shan Mountains, Central Asia. Global and Planetary Change, 56(3), 311-327.

Mark, B. G. et al. (2015). Glaciers as water resources. The High-Moutain Cryosphere, 184-203.

Marzeion, B., et al. (2014). Attribution of global glacier mass loss to anthropogenic and natural causes. Science, 345(6199), 919-921.

Marzeion, B., Jarosch, A. H., \& Hofer, M. (2012). Past and future sea-level change from the surface mass balance of glaciers. The Cryosphere, 6(6), 1295-1322.

Maskey, S., Uhlenbrook, S., \& Ojha, S. (2011). An analysis of snow cover changes in the Himalayan region using MODIS snow products and in-situ temperature data. Climatic Change, $108(1), 391$.

Maurer, J. M., Rupper, S. B., \& Schaefer, J. M. (2016). Quantifying ice loss in the eastern Himalayas since 1974 using declassified spy satellite imagery. The Cryosphere Discussions, (April), 1-20.

Maussion, F., et al. (2014). Precipitation Seasonality and Variability over the Tibetan Plateau as Resolved by the High Asia Reanalysis. Journal of Climate, 27(5), 1910-1927.

Mayewski, P. A., \& Jeschke, P. A. (1979). Himalayan and Trans-Himalayan Glacier Fluctuations Since AD 1812. Arctic and Alpine Research, 11(3), 267.

Mayewski, P. A., Lyons, W. B., \& Ahmad, N. (1983). Chemical composition of a high altitude fresh snowfall in the Ladakh Himalayas. Geophysical Research Letters, 10(1), 105-108.

Ménégoz, M., et al. (2014). Snow cover sensitivity to black carbon deposition in the Himalayas: From atmospheric and ice core measurements to regional climate simulations. Atmospheric Chemistry and Physics, 14(8), 4237-4249. 
Mergili, M., Müller, J. P., \& Schneider, J. F. (2013). Spatio-temporal development of high-mountain lakes in the headwaters of the Amu Darya River (Central Asia). Global and Planetary Change, 107, 13-24.

Miles, E. S., et al. (2016). Refined energy-balance modelling of a supraglacial pond, Langtang Khola, Nepal. Annals of Glaciology, 57(71), 29-40.

Miller, J. D., Immerzeel, W. W., \& Rees, G. (2012). Climate change impacts on glacier hydrology and River discharge in the Hindu Kush-Himalayas A Synthesis of the Scientific Basis. Mountain Research and Development, 32(4), 461-467.

Ming, J., et al. (2012). Darkening of the mid-Himalaya glaciers since 2000 and the potential causes. Environmental Research Letters, 7 (1), 14021 .

Minora, U., et al. (2016). Glacier area stability in the Central Karakoram National Park (Pakistan) in 2001-2010: The "Karakoram Anomaly" in the spotlight. Progress in Physical Geography, 40 (5), 629-660.

Mountain Research Initiative EDW Working Group. (2015). Elevation-dependent warming in mountain regions of the world. Nature Climate Change, 5(5), 424-430.

Mukhopadhyay, B. 2012. Signature and hydrologic consequences of climate change within the upper-middle Brahmaputra Basin. Hydrological Processes.

Mukhopadhyay, B., \& Khan, A. (2015). A reevaluation of the snowmelt and glacial melt in river flows within Upper Indus Basin and its significance in a changing climate. Journal of Hydrology, 527, 119-132.

Nagai, H., Fujita, K., Sakai, A., Nuimura, T., \& Tadono, T. (2016). Comparison of multiple glacier inventories with a new inventory derived from high-resolution ALOS imagery in the Bhutan Himalaya. The Cryosphere, 10(1), 65-85.

Naito, N. et al. (2000). Numerical simulation of recent shrinkage of Khumbu Glacier, Nepal Himalayas. In Debris-covered Glaciers: Proceedings of an International Workshop Held at the University of Washington in Seattle, Washington, USA, 13-15 September 2000. pp. $245-254$.

Nan, Z., Li, S., \& Cheng, G. (2005). Prediction of permafrost distribution on the Qinghai-Tibet Plateau in the next 50 and 100 years. Science in China Series D, 48(6), 797.

Neckel, N., Braun, A., Kropáček, J., \& Hochschild, V. (2013). Recent mass balance of the Purogangri Ice Cap, central Tibetan Plateau, by means of differential X-band SAR interferometry. The Cryosphere, 7(5), 1623-1633.

Neckel, N., et al. (2014). Glacier mass changes on the Tibetan Plateau 2003-2009 derived from ICESat laser altimetry measurements. Environmental Research Letters, 9(1), 14009.

Nepal, S., et al. (2013). Understanding the hydrological system dynamics of a glaciated alpine catchment in the Himalayan region using the J2000 hydrological model. Hydrological Processes, 28(3), 1329-1344.

Nie, Y., et al. (2010). Monitoring glacier change based on remote sensing in the Mt. Qomolangma National Nature Preserve, 19762006. Acta Geographica Sinica, 65(1), 13-28.

Niu, H. et al. (2016). Chemical compositions of snow from Mt. Yulong, southeastern Tibetan Plateau. Journal of Earth System Science, 125 (2), 403-416.

Niu, L., et al. (2011). Effect of permafrost degradation on hydrological processes in typical basins with various permafrost coverage in Western China. Science China Earth Sciences, 54(4), 615-624.

Nuimura, T., et al. (2012). Elevation changes of glaciers revealed by multitemporal digital elevation models calibrated by GPS survey in the Khumbu region, Nepal Himalaya, 1992-2008. Journal of Glaciology, 58(210), 648-656.
Nuimura, T., et al. (2015). The GAMDAM glacier inventory: A quality-controlled inventory of Asian glaciers. Cryosphere, 9(3), 849-864.

O'Neel, S., et al. (2014). Assessing streamflow sensitivity to variations in glacier mass balance. Climatic Change, 123(2), 329-341.

O'Reilly, C. M. et al. (2015). Rapid and highly variable warming of lake surface waters around the globe. Geophysical Research Letters, 42(24), 10,773-10,781.

Oerlemans, J. (2005). Extracting a Climate Signal from 169 Glacier Records. Science, 308, 675-677.

Ohara, N., et al. (2014). Dynamic Equilibrium Glacier modeling under evolving climate condition. World Environmental and Water Resources Congress, 2014, 608-615.

Ojha, S., et al. (2016). Glacier area shrinkage in eastern Nepal Himalaya since 1992 using high-resolution inventories from aerial photographs and ALOS satellite images. Journal of Glaciology, 62, 1-13.

Ojha, S., et al. (2017). Topographic controls on the debris-cover extent of glaciers in the Eastern Himalayas: Regional analysis using a novel high-resolution glacier inventory. Quaternary International, 455, 82-92.

Owen, L. A., \& England, J. (1998). Observations on rock glaciers in the Himalayas and Karakoram mountains of northern Pakistan and India. Geomorphology, 26(1-3), 199-213.

Osipova, G., \& Khromova, T. (2010). Elektronnaja baza dannykh "Pulsiruyuzhchne ledniki Pamira" (= Electronic database of surging glaciers in the Pamirs). Лёд и Снег (Ice and Snow), 4, 15-24.

Palazzi, E., et al. (2013). Precipitation in the hindu-kush karakoram himalaya: Observations and future scenarios. Journal of Geophysical Research Atmospheres, 118(1), 85-100.

Pan, B. T., et al. (2012). Glacier changes from 1966-2009 in the Gongga Mountains, on the south-eastern margin of the Qinghai-Tibetan Plateau and their climatic forcing. Cryosphere, 6 (5), 1087-1101.

Pande, K., et al. (2000). Stable isotope systematics of surface water bodies in the Himalayan and Trans-Himalayan (Kashmir) region. Journal of Earth System Science, 109(1), 109-115.

Pandey, P., Kulkarni, A. V., \& Venkataraman, G. (2013). Remote sensing study of snowline altitude at the end of melting season, Chandra-Bhaga basin, Himachal Pradesh, 1980-2007. Geocarto International, 28(4), 311-322.

Paul, F., et al. (2013). On the accuracy of glacier outlines derived from remote-sensing data. Annals of Glaciology, 54(63), 171-182.

Paul, F., et al. (2004). Rapid disintegration of Alpine glaciers observed with satellite data. Geophysical Research Letters, 31(21), 12-15.

Paul, F. (2015). Revealing glacier flow and surge dynamics from animated satellite image sequences: Examples from the Karakoram. Cryosphere, 9(6), 2201-2214.

Paul, F. et al. (2002). The new remote-sensing derived Swiss glacier inventory. 1. Methods. Annals of Glaciology, 34(September 1985), $355-361$.

Pellicciotti, F., et al. (2015). Mass-balance changes of the debris-covered glaciers in the Langtang Himal, Nepal, from 1974 to 1999. Journal of Glaciology, 61(226), 373-386.

Pfeffer, W. T., et al. (2014). The Randolph Glacier Inventory: A globally complete inventory of glaciers. Journal of Glaciology, 60, 537-552.

Pieczonka, T., \& Bolch, T. (2015). Region-wide glacier mass budgets and area changes for the Central Tien Shan between $\sim 975$ and 1999 using Hexagon KH-9 imagery. Global and Planetary Change, $128,1-13$.

Pu, Z., \& Xu, L. (2009). MODIS/Terra observed snow cover over the Tibet Plateau: Distribution, variation and possible connection with the East Asian Summer Monsoon (EASM). Theoretical and Applied Climatology, 97(3-4), 265-278. 
Pu, Z., Xu, L., \& Salomonson, V. V. (2007). MODIS/Terra observed seasonal variations of snow cover over the Tibetan Plateau. Geophysical Research Letters, 34(6), 1-6.

Putkonen, J. K. (2004). Continuous Snow and rain data at 500 to $4400 \mathrm{~m}$ Altitude near Annapurna, Nepal, 1999-2001. Arctic, Antarctic, and Alpine Research, 36(2), 244-248.

Qian, Y., et al. (2011). Sensitivity studies on the impacts of Tibetan Plateau snowpack pollution on the Asian hydrological cycle and monsoon climate. Atmospheric Chemistry and Physics, 11(5), 1929-1948.

Qin, D., Liu, S., \& Li, P. (2006). Snow cover distribution, variability, and response to climate change in Western China. Journal of Climate, 19(9), 1820-1833.

Quincey, D. J., et al. (2007). Early recognition of glacial lake hazards in the Himalaya using remote sensing datasets. Global and Planetary Change, 56(1), 137-152.

Quincey, D. J., et al. (2011). Karakoram glacier surge dynamics. Geophysical Research Letters, 38(18), 2-7.

Racoviteanu, A. E., Armstrong, R., \& Williams, M. W. (2013). Evaluation of an ice ablation model to estimate the contribution of melting glacier ice to annual discharge in the Nepal Himalaya. Water Resources Research, 49(9), 5117-5133.

Radić, V., et al. (2014). Regional and global projections of twenty-first century glacier mass changes in response to climate scenarios from global climate models. Climate Dynamics, 42(1-2), 37-58.

Radić, V., \& Hock, R. (2014). Glaciers in the Earth's hydrological cycle: Assessments of Glacier Mass and Runoff changes on global and regional scales. Surveys in Geophysics, 35(3), 813-837.

Ragettli, S., et al. (2013). Sources of uncertainty in modeling the glaciohydrological response of a Karakoram watershed to climate change. Water Resources Research, 49(9), 6048-6066.

Ragettli, S., et al. (2015). Unraveling the hydrology of a Himalayan catchment through integration of high resolution in situ data and remote sensing with an advanced simulation model. Advances in Water Resources, 78, 94-111.

Rai, S. P., et al. (2016). Isotopic characteristics of cryospheric waters in parts of Western Himalayas, India. Environmental Earth Sciences, 75(7), 600.

Ramanathan, V., \& Carmichael, G. (2008). Global and regional climate changes due to black carbon. Nature Geoscience, 1, 221-227.

Ran, Y., et al. (2012). Distribution of Permafrost in China: An overview of existing Permafrost maps. Permafrost and Periglacial Processes, 23(4), 322-333.

Rastogi, S.P. \& Narayan, S., 1999. Permafrost in the Tso Kar Basin, Ladakh. In Proceedings of the Symposium for Snow, Ice and Glaciers, March 1999, Geological Survey of India Special Publication (pp. 315-319).

Reager, J. T., et al. (2016). A decade of sea level rise slowed by climate-driven hydrology. Science, 351(6274), 699-703.

Rees, H. G., \& Collins, D. N. (2006). Regional differences in response of flow in glacier-fed Himalayan rivers to climatic warming. Hydrological Processes, 20, 2157-2169.

Reggiani, P., et al. (2017). A joint analysis of river runoff and meteorological forcing in the Karakoram, upper Indus Basin. Hydrological Processes, 31(2), 409-430.

Regmi, D. (2008). Rock Glacier distribution and the lower limit of discontinuous mountain permafrost in the Nepal Himalaya. In Proceedings of the Ninth International Conference on Permafrost (NICOP), June 29-July 3, 2008, Alaska Fairbanks (pp. 14751480).

Richardson, S. D., \& Reynolds, J. M. (2000). An overview of glacial hazards in the Himalayas. Quaternary International, 65, 31-47.

Rikiishi, K., \& Nakasato, H. (2006). Height dependence of the tendency for reduction in seasonal snow cover in the Himalaya and the Tibetan Plateau region, 1966-2001. Annals of Glaciology, 43 (1), 369-377.

Robinson, D. A., \& Dewey, K. F. (1990). Recent secular variations in the extent of Northern Hemisphere snow cover. Geophysical Research Letters, 17(10), 1557-1560.

Rohrer, M., et al. (2013). Missing (in-situ) snow cover data hampers climate change and runoff studies in the Greater Himalayas. Science of the Total Environment, 468-469, S60-S70.

Romanovsky, V. E., Smith, S. L., \& Christiansen, H. H. (2010). Permafrost thermal state in the polar Northern Hemisphere during the international polar year 2007-2009: a synthesis. Permafrost and Periglacial Processes, 21(2), 106-116.

Rounce, D. R., et al. (2016). A new remote hazard and risk assessment framework for glacial lakes in the Nepal Himalaya. Hydrology and Earth System Sciences, 20(9), 3455-3475.

Rowan, A. V., et al. (2015). Modelling the feedbacks between mass balance, ice flow and debris transport to predict the response to climate change of debris-covered glaciers in the Himalaya. Earth and Planetary Science Letters, 430, 427-438.

Rupper, S., et al. (2012). Sensitivity and response of Bhutanese glaciers to atmospheric warming. Geophysical Research Letters, 39(19), $1-6$.

Sakai, A., et al. (2000a). Role of supraglacial ponds in the ablation process of a debris-covered glacier in the Nepal Himalayas. International Association of Hydrological Sciences, 264, 119-130.

Sakai, A., Chikita, K., \& Yamada, T. (2000b). Expansion of a moraine-dammed glacial lake, Tsho Rolpa, in Rolwaling Himal, Nepal Himalaya. Limnology and Oceanography, 45(6), 1401-1408.

Sakai, A., Nakawo, M., \& Fujita, K. (2002). Distribution characteristics and energy balance of ice cliffs on debris-covered glaciers, Nepal Himalaya. Arctic, Antarctic, and Alpine Research, 34(1), 12.

Sakai, A., et al. (2015). Climate regime of Asian glaciers revealed by GAMDAM glacier inventory. The Cryosphere, 9(3), 865-880.

Sakai, A., \& Fujita, K. (2017). Contrasting glacier responses to recent climate change in high-mountain Asia. Scientific Reports, 7(1), 13717.

Salzmann, N. et al. (2014). Data and knowledge gaps in glacier, snow and related runoff research-A climate change adaptation perspective. Journal of Hydrology, 518(PB), 225-234.

Sarikaya, M. A., et al. (2012). Space-based observations of Eastern Hindu Kush glaciers between 1976 and 2007, Afghanistan and Pakistan. Remote Sensing Letters, 3(1), 77-84.

Savoskul, O.S., \& Smakhtin, V. (2013). Glacier systems and seasonal snow cover in six major Asian river basins: Hydrological role under changing climate, Colombo, Sri Lanka: International Water Management Institute (IWMI).

Schaner, N., et al. (2012). The contribution of glacier melt to streamflow. Environmental Research Letters, 7(3), 34029.

Scherler, D., Bookhagen, B., \& Strecker, M. R. (2011). Spatially variable response of Himalayan glaciers to climate change affected by debris cover. Nature Geoscience, 4(3), 156-159.

Schmid, M. O., et al. (2015). Assessment of permafrost distribution maps in the Hindu Kush Himalayan region using rock glaciers mapped in Google Earth. Cryosphere, 9(6), 2089-2099.

Schmidt, S., \& Nüsser, M. (2012). Changes of High Altitude Glaciers from 1969 to 2010 in the Trans-Himalayan Kang Yatze Massif, Ladakh, Northwest India. Arctic, Antarctic, and Alpine Research, 44(1), 107-121.

Schmidt, S., \& Nüsser, M. (2009). Fluctuations of Raikot Glacier during the past 70 years: a case study from the Nanga Parbat massif, northern Pakistan. Journal of Glaciology, 55, 949-959.

Serreze, M. C., \& Barry, R. G. (2011). Processes and impacts of Arctic amplification: A research synthesis. Global and Planetary Change, $77(1-2), 85-96$. 
Sevestre, H., \& Benn, D. I. (2015). Climatic and geometric controls on the global distribution of surge-type glaciers: implications for a unifying model of surging. Journal of Glaciology, 61(228), 646-662.

Shangguan, D., et al. (2016). Characterizing the May 2015 Karayaylak Glacier surge in the eastern Pamir Plateau using remote sensing. Journal of Glaciology, 62(235), 944-953.

Shangguan, D., et al. (2014). Glacier changes in the Koshi River basin, central Himalaya, from 1976 to 2009, derived from remote-sensing imagery. Annals of Glaciology, 55(66), 61-68.

Shangguan, D., et al. (2007). Glacier changes in the west Kunlun Shan from 1970 to 2001 derived from Landsat TM/ETM + and Chinese glacier inventory data. Annals of Glaciology, 46, 204-208.

Sharif, M., et al. (2013). Trends in timing and magnitude of flow in the Upper Indus Basin. Hydrology and Earth System Sciences, 17(4), 1503-1516.

Shchetinnikov, A. S. (1993). Izmenenie pazmerov olodenia Pamiro-Alaya za 1957-1980 gody (Investigations on glaciation in Pamir-Alay between 1957 and 1980). Data of Glaciological Studies, 76, 77-83.

Shea, J. M., et al. (2015a). A comparative high-altitude meteorological analysis from three catchments in the Nepalese Himalaya. International Journal of Water Resources Development, 31(2), 174-200.

Shea, J. M., et al. (2015b). Modelling glacier change in the Everest region, Nepal Himalaya. Cryosphere, 9(3), 1105-1128.

Shea, J. M., \& Immerzeel, W. W. (2016). An assessment of basin-scale glaciological and hydrological sensitivities in the Hindu KushHimalaya. Annals of Glaciology, 57(71), 308-318.

Shen, S. S. P., et al. (2015). Characteristics of the Tibetan Plateau snow cover variations based on daily data during 1997-2011. Theoretical and Applied Climatology, 120(3), 445-453.

Sherpa, S. F., et al. (2017). Contrasted surface mass balances of debris-free glaciers observed between the southern and the inner parts of the Everest region (2007-15). Journal of Glaciology, 63 (240), 637-651.

Shi, Y., et al. (2008). Concise Glacier Inventory of China. Shanghai, China.: Shanghai Popular Science Press.

Shiraiwa, T. (1992). Freeze-thaw activities and rock breakdown in the Langtang Valley, Nepal Himalaya. Environmental science, Hokkaido University: Journal of the Graduate School of Environmental Science, 15(1), 1-12.

Shrestha, A. B., et al. (1999). Maximum temperature trends in the Himalaya and its vicinity: An analysis based on temperature records from Nepal for the period 1971-94. Journal of Climate, 12(9), 2775-2786.

Shrestha, A. B., et al. (2000). Precipitation fluctuations in the Himalaya and its vicinity: An analysis based on temperature records from Nepal. International Journal of Climate, 20, 317-327.

Shrestha, A. B., \& Aryal, R. (2011). Climate change in Nepal and its impact on Himalayan glaciers. Regional Environmental Change, 11 (1), 65-77.

Shrestha, D., Singh, P., \& Nakamura, K. (2012). Spatiotemporal variation of rainfall over the central Himalayan region revealed by TRMM precipitation radar. Journal of Geophysical Research Atmospheres, 117(22), 1-14.

Shroder, J. (2011). In V. Singh, P. Singh \& U. Haritashya (Eds.), Encyclopedia of snow, ice and glaciers. Springer Science \& Business Media.

$\mathrm{Si}$, Y. et al. (2015). Impacts of climate variability on river ice phenology of Ningxia-Inner Mongolia reach in the upper Yellow River. In E-proceedings of the 36th IAHR World Congress 28 June3 July, 2015, The Hague, The Netherlands.
Singh, P., \& Bengtsson, L. (2005). Impact of warmer climate on melt and evaporation for the rainfed, snowfed and glacierfed basins in the Himalayan region. Journal of Hydrology, 300(1), 140-154.

Singh, P., \& Jain, S. K. (2002). Snow and glacier melt in the Satluj River at Bhakra Dam in the western Himalayan region. Hydrological Sciences Journal, 47(1), 93-106.

Singh, P., \& Kumar, N. (1997). Impact assessment of climate change on the hydrological response of a snow and glacier melt runoff dominated Himalayan river. Journal of Hydrology, 193(1-4), $316-350$.

Singh, S. K., et al. (2014). Snow cover variability in the Himalayan-Tibetan region. International Journal of Climatology, 34(2), 446-452.

Smith, T., \& Bookhagen, B. (2016). Assessing uncertainty and sensor biases in passive microwave data across High Mountain Asia. Remote Sensing of Environment, 181, 174-185.

Soncini, A. et al. (2016). Future hydrological regimes and glacier cover in the Everest region: The case study of the upper Dudh Koshi basin. Science of The Total Environment.

Soncini, A. et al. (2015). Future hydrological regimes in the Upper Indus Basin: A case study from a high-altitude Glacierized Catchment. http://dx.doi.org/10.1175/JHM-D-14-0043.1.

Spiess, M., Schneider, C., \& Maussion, F. (2016). MODIS-derived interannual variability of the equilibrium-line altitude across the Tibetan Plateau. Annals of Glaciology, 57(71), 140-154.

Stewart, I. T. (2009). Changes in snowpack and snowmelt runoff for key mountain regions. Hydrological Processes, 23(1), 78-94.

Su, Z., \& Shi, Y. (2002). Response of monsoonal temperate glaciers to global warming since the Little Ice Age. Quaternary International, 97-98, 123-131.

Sun, M., Liu, S., \& Yao, X. (2015). Glacier changes in the Qilian Mountains in the past half century: Based on the revised first and second Chinese glacier inventory. Acta Geographica Sinica, 70(9), $1402-1414$.

Tahir, A. A. et al. (2016). Comparative assessment of spatiotemporal snow cover changes and hydrological behavior of the Gilgit, Astore and Hunza River basins (Hindukush-Karakoram-Himalaya region, Pakistan). Meteorology and Atmospheric Physics, 1-19.

Tahir, A. A., et al. (2011). Modeling snowmelt-runoff under climate scenarios in the Hunza River basin, Karakoram Range, Northern Pakistan. Journal of Hydrology, 409(1-2), 104-117.

Tedesco, M., \& Miller, J. (2007). Observations and statistical analysis of combined active-passive microwave space-borne data and snow depth at large spatial scales. Remote Sensing of Environment, 111 (2-3), 382-397.

Terzago, S. et al. (2014). Snowpack changes in the Hindu-Kush Karakoram Himalaya from CMIP5 Global Climate Models. Journal of Hydrometeorology.

Thakuri, S. et al. (2014). Tracing glacier changes since the 1960s on the south slope of Mt. Everest (central Southern Himalaya) using optical satellite imagery. The Cryosphere, 8(4), 1297-1315.

Thayyen, R. J., \& Gergan, J. T. (2010). Role of glaciers in watershed hydrology: a preliminary study of a Himalayan catchment. The Cryosphere, 4(1), 115-128.

Thayyen, R. J., Rai, S. P., \& Goel, M. K. (2015). Glaciological studies of Phuche glacier, Ladakh Range. Roorkee: India.

Thompson, L. G., et al. (2000). A high-resolution millennial record of the South asian monsoon from himalayan ice cores. Science, 289 (5486), 1916-1920.

Thompson, S., et al. (2016). Stagnation and mass loss on a Himalayan debris-covered glacier: Processes, patterns and rates. Journal of Glaciology, 62(233), 467-485. 
Tian, H., Yang, T., \& Liu, Q. (2014). Climate change and glacier area shrinkage in the Qilian mountains, China, from 1956 to 2010. Annals of Glaciology, 55(66), 187-197.

Tiwari, S., Kar, S. C., \& Bhatla, R. (2016). Interannual variability of snow water equivalent (SWE) over Western Himalayas. Pure and Applied Geophysics, 173(4), 1317-1335.

Torre Jorgenson, M., et al. (2013). Reorganization of vegetation, hydrology and soil carbon after permafrost degradation across heterogeneous boreal landscapes. Environmental Research Letters, 8(3), 35017.

Turner, A. G., \& Annamalai, H. (2012). Climate change and the South Asian summer monsoon. Nature Climate Change, 2(8), 587-595.

Unger-Shayesteh, K. et al. (2013). What do we know about past changes in the water cycle of Central Asian headwaters? A review. Global and Planetary Change, 110, Part, 4-25.

Vincent, C., et al. (2013). Balanced conditions or slight mass gain of glaciers in the Lahaul and Spiti region (northern India, Himalaya) during the nineties preceded recent mass loss. The Cryosphere, 7(2), 569-582.

Vincent, C., et al. (2016). Reduced melt on debris-covered glaciers: Investigations from Changri Nup Glacier, Nepal. Cryosphere, 10 (4), 1845-1858.

Viste, E., Sorteberg, A., \& Renssen, H. (2015). Snowfall in the Himalayas: an uncertain future from a little-known past. The Cryosphere, 9(3), 1147-1167.

Vuyovich, C., \& Jacobs, J. M. (2011). Snowpack and runoff generation using AMSR-E passive microwave observations in the Upper Helmand Watershed, Afghanistan. Remote Sensing of Environment, 115(12), 3313-3321.

Wagnon, P., et al. (2013). Seasonal and annual mass balances of Mera and Pokalde glaciers (Nepal Himalaya) since 2007. The Cryosphere, 7(6), 1769-1786.

Wang, S., et al. (2000). Permafrost degradation on the Qinghai-Tibet Plateau and its environmental impacts. Permafrost and Periglacial Processes, 11(1), 43-53.

Wang, F. et al. (2015). China, the millennium development goals, and the post-2015 development agenda, Beijing.

Wang, K., et al. (2015a). Research for glaciers and climate change of Anyemaqen Mountain nearly 30 years. Research of Soil \& Water Conservation, 22(3), 300-303308. (in Chinese).

Wang, W. et al. (2015b). Integrated hazard assessment of Cirenmaco glacial lake in Zhangzangbo valley, Central Himalayas. Geomorphology.

Wang, W., et al. (2015c). Spatio-temporal change of snow cover and its response to climate over the Tibetan Plateau based on an improved daily cloud-free snow cover product. Remote Sensing, 7(1), 169.

Wang, N., \& Ding, L. (2002). Study on the glacier variation in Bujiagangri section of the east Tanggula range since the Little Ice Age. Journal of Glaciology and Geogryology, 24(3), 234-244. (in Chinese).

Wang, T., et al. (2013a). Declining snow cover may affect spring phenological trend on the Tibetan Plateau. Proceedings of the National Academy of Sciences, 110(31), E2854-E2855.

Wang, X., et al. (2013b). Glacier and glacial lake changes and their relationship in the context of climate change, Central Tibetan Plateau 1972-2010. Global and Planetary Change, 111, 246-257.

Wang, X. et al. (2012). Glacier temporal-spatial change characteristics in western Nyainqentanglha Range, Tibetan Plateau 1977-2010. Earth Science/Diqiu Kexue, 37(5).

Wang, Z. (1991). The glacier and environment in the middle sector of Tianshan and the eastern sector of Qilianshan since the Little Ice Age. Acta Geographica Sinica, 46, 160-168.

Wei, J., et al. (2014). Surface-area changes of glaciers in the Tibetan Plateau interior area since the 1970s using recent Landsat images and historical maps. Annals of Glaciology, 55(66), 213-222.
Wei, Z., \& Dong, W. (2015). Assessment of simulations of snow depth in the Qinghai-Tibetan Plateau using CMIP5 multi-models. Arctic, Antarctic, and Alpine Research, 47(4), 525-611.

Wendt, A., Mayer, C., Lambrecht, A., \& Floricioiu, D. (2017). A glacier surge of Bivachny Glacier. Pamir Mountains, observed by a time series of high-resolution digital elevation models and glacier velocities, Remote Sensing, 9(4), 2072-4292.

Westermann, S. et al. (2014). Remote sensing of permafrost and frozen ground. In Remote sensing of the cryosphere (pp. 307-344). Chichester, UK: Wiley.

Williams, M. W., et al. (2016). Using geochemical and isotopic chemistry to evaluate glacier melt contributions to the Chamkar Chhu (river), Bhutan. Annals of Glaciology, 57(71), 339-348.

Wilson, A. M., et al. (2015). Use of a hydrologic mixing model to examine the roles of meltwater, precipitation and groundwater in the Langtang River basin, Nepal. Annals of Glaciology, 57(71), 155-168.

Wiltshire, A. J. (2014). Climate change implications for the glaciers of the Hindu Kush, Karakoram and Himalayan region. Cryosphere, 8 (3), 941-958.

Winiger, M., Gumpert, M., \& Yamout, H. (2005). Karakorum-Hindukush-western Himalaya: Assessing high-altitude water resources. Hydrological Processes, 19(12), 2329-2338.

Wu, G., \& Zhang, Y. (1998). Tibetan Plateau Forcing and the timing of the Monsoon onset over South Asia and the South China Sea. Monthly Weather Review, 126(4), 913-927.

$\mathrm{Wu}, \mathrm{H}$., et al. (2014). Regional glacier mass loss estimated by ICESat-GLAS data and SRTM digital elevation model in the West Kunlun Mountains, Tibetan Plateau, 2003-2009. Journal of Applied Remote Sensing, 8(1), 83515.

Wu, Q., \& Zhang, T. (2008). Recent permafrost warming on the Qinghai-Tibetan Plateau. Journal of Geophysical Research, 113 (D13), D13108.

Wu, Q., Zhang, T., \& Liu, Y. (2010). Permafrost temperatures and thickness on the Qinghai-Tibet Plateau. Global and Planetary Change, 72(1), 32-38.

Wu, Q., Zhang, T., \& Liu, Y. (2012). Thermal state of the active layer and permafrost along the Qinghai-Xizang (Tibet) Railway from 2006 to 2010. The Cryosphere, 6(3), 607-612.

Wulf, H., Bookhagen, B., \& Scherler, D. (2016). Differentiating between rain, snow, and glacier contributions to river discharge in the western Himalaya using remote-sensing data and distributed hydrological modeling. Advances in Water Resources, 88, 152-169.

Xiang, Y., Gao, Y., \& Yao, T. (2014). Glacier change in the Poiqu River basin inferred from Landsat data from 1975 to 2010. Quaternary International, 349, 392-401.

Xiao, C., et al. (2007). Observed changes of cryosphere in China over the second half of the 20th century: an overview. Annals of Glaciology, 46, 382-390.

$\mathrm{Xu}$, J. et al., 2013. Recent changes in glacial area and volume on Tuanjiefeng peak region of Qilian Mountains. In Q. China \& Sun (Eds.), PLoS One, (Vol. 8(8), p. e70574).

$\mathrm{Xu}$, J., et al. (2009). The melting Himalayas: Cascading effects of climate change on water, biodiversity, and livelihoods. Conservation Biology, 23(3), 520-530.

Xu, Y., Ramanathan, V., \& Washington, W. M. (2016). Observed high-altitude warming and snow cover retreat over Tibet and the Himalayas enhanced by black carbon aerosols. Atmospheric Chemistry and Physics, 16(3), 1303-1315.

Yao, T., et al. (2012). Different glacier status with atmospheric circulations in Tibetan Plateau and surroundings. Nature Climate Change, 2(9), 663-667.

Yao, T., et al. (2007). Recent Glacial Retreat and its impact on Hydrological processes on the Tibetan Plateau, China, and surrounding regions. Arctic, Antarctic, and Alpine Research, 39 (4), 642-650. 
Yasuda, T., \& Furuya, M. (2015). Dynamics of surge-type glaciers in West Kunlun Shan, Northwestern Tibet. Journal of Geophysical Research: Earth Surface, 120(11), 2393-2405.

Yasuda, T., \& Furuya, M. (2013). Short-term glacier velocity changes at West Kunlun Shan, Northwest Tibet, detected by Synthetic Aperture Radar data. Remote Sensing of Environment, 128, 87-106.

Ye, B. et al. (2005). The Urumqi River source Glacier No. 1, Tianshan, China: Changes over the past 45 years. Geophysical Research Letters, 32, 21504.

Ye, Q., Zong, J., Tian, L., Cogley, J. G., Song, C., \& Guo, W. (2017). Glacier changes on the Tibetan Plateau derived from Landsat imagery: Mid-1970s-2000-13. Journal of Glaciology, 63(238), 273-287.

Yi, S., \& Sun, W. (2014). Evaluation of glacier changes in high-mountain Asia based on 10 year GRACE RL05 models. Journal of Geophysical Research: Solid Earth, 119(3), 2504-2517.

Yin, Z.-Y., et al. (2008). An assessment of the biases of satellite Rainfall Estimates over the Tibetan Plateau and Correction methods based on Topographic analysis. Journal of Hydrometeorology, 9(3), 301-326.

Zemp, M. et al. (2015). Global glacier change bulletin no. 1 (20122013), Zurich, Switzerland.

Zhang, G., Yao, T., et al. (2015a). An inventory of glacial lakes in the Third Pole region and their changes in response to global warming. Global and Planetary Change, 131, 148-157.

Zhang, Y., et al. (2015b). Glacier runoff and its impact in a highly glacierized catchment in the southeastern Tibetan Plateau: Past and future trends. Journal of Glaciology, 61(228), 713-730.

Zhang, G., et al. (2013). Increased mass over the Tibetan Plateau: From lakes or glaciers? Geophysical Research Letters, 40(10), 2125 2130.

Zhang, G. et al. (2012). Snow cover dynamics of four lake basins over Tibetan Plateau using time series MODIS data (2001-2010). Water Resources Research, 48(10), p.n/a-n/a.
Zhang, T., et al. (2008a). Statistics and characteristics of permafrost and ground-ice distribution in the Northern Hemisphere. Polar Geography, 31(1-2), 47-68.

Zhang, Y., et al. (2008b). Glacier change and glacier runoff variation in the Tuotuo River basin, the source region of Yangtze River in western China. Environmental Geology, 56(1), 59-68.

Zhang, X. et al. (2001). Variation of precipitation $\delta^{18} \mathrm{O}$ in Langtang Valley Himalayas. Science in China Series D: Earth Sciences, 44 (9), 769-778.

Zhang, Y., Hirabayashi, Y., \& Liu, S. (2012). Catchment-scale reconstruction of glacier mass balance using observations and global climate data: case study of the Hailuogou catchment, south-eastern Tibetan Plateau. Journal of Hydrology, 444, 146-160.

Zhang, Y., Liu, S., \& Ding, Y. (2007). Glacier meltwater and runoff modelling, Keqicar Baqi glacier, southwestern Tien Shan, China. Journal of Glaciology, 53(180), 91-98.

Zhang, Z. et al. (2016). Mass Change of Glaciers in Muztag AtaKongur Tagh, Eastern Pamir, China from 1971/76 to 2013/14 as Derived from Remote Sensing Data. PLoS One (pp. 1-19).

Zhao, L., et al. (2010). Thermal state of permafrost and active layer in Central Asia during the international polar year. Permafrost and Periglacial Processes, 21(2), 198-207.

Zhao, L., Ding, R., \& Moore, J. C. (2014). Glacier volume and area change by 2050 in high mountain Asia. Global and Planetary Change, 122, 197-207.

Zhou, G., et al. (2007). Mass balance of the Zhadang glacier in the central Tibetan Plateau. Journal of Glaciology Geocryol, 29(3), 360-365.

Zhou, H., Aizen, E., \& Aizen, V. (2013). Deriving long term snow cover extent dataset from AVHRR and MODIS data: Central Asia case study. Remote Sensing of Environment, 136, 146-162.

Zhou, Y., Li, Z., \& Li, J. (2017). Slight glacier mass loss in the Karakoram region during the 1970 s to 2000 revealed by KH-9 images and SRTM DEM. Journal of Glaciology, 63(238), 331-342.
Open Access This chapter is licensed under the terms of the Creative Commons Attribution 4.0 International License (http:// creativecommons.org/licenses/by/4.0/), which permits use, sharing, adaptation, distribution and reproduction in any medium or format, as long as you give appropriate credit to the original author(s) and the source, provide a link to the Creative Commons license and indicate if changes were made.
The images or other third party material in this chapter are included in the chapter's Creative Commons license, unless indicated otherwise in a credit line to the material. If material is not included in the chapter's Creative Commons license and your intended use is not permitted by statutory regulation or exceeds the permitted use, you will need to obtain permission directly from the copyright holder. 